\title{
WARIANTY ARGUMENTACJI KINETYCZNEJ ZA ISTNIENIEM BOGA*
}

\author{
WPROWADZENIE W PROBLEMATYKE
}

1. Analizę i próbę krytycznej oceny argumentacji z ruchu podjąłem po raz pierwszy w szkicu Kinetyczny dowód istnienia Boga wobec nowych zarzutów ${ }^{1}$. Stanowisko, jakie zająłem w tym artykule, było jednak zbyt skrajne. Utrzymywałem w nim bowiem, mając na uwadze ruch lokalny, że „nie znamy w przyrodzie żadnej akcji ruchowej, której nie dałoby się wytłumaczyć adekwatnie, bez reszty, przez własne siły przyrody tak, iż myśl o ponadświatowym pierwszym motorze nieruchomym okazuje się bezprzedmiotowa" ${ }^{2}$.

Nic dziwnego, że moja postawa wobec argumentacji z ruchu lokalnego, jaką zająłem we wskazanym artykule, spotkała się z zastrzeżeniami poczynionymi $\mathrm{z}$ wielu stron. Wyrazem tych zastrzeżeń był najpierw artykuł Witolda Pietkuna Dowód kinetyczny wobec teorii kwantów ${ }^{3}$. W artykule tym Pietkun zarzucił mi, że w moich wypowiedziach „przejawia się przecenianie argumentacji na płaszczyźnie fizykalnej w porównaniu z argumentacją ściśle metafizyczną" ${ }^{4}$. Ponadto Pietkun zakwestionował poprawność mego ujęcia nawet $z$ punktu widzenia samej fizyki ${ }^{5}$. Do zastrzeżeń wobec mego stanowiska Pietkun powrócił jeszcze w referacie, jaki wygłosił na posiedzeniu sekcji filozoficznej Warszawskiego

* Artykuł ten stanowi wynik prac badawczych prowadzonych przez ks. prof. Kazimierza Kłósaka w ciągu ostatnich dni Jego życia. Początkowym zamiarem Autora było przygotowanie większej całości, która miała być wydana przez Polskie Towarzystwo Teologiczne $w$ Krakowie jako drugi tom rozprawy $Z$ zagadnień filozoficznego poznania Boga. Początkowe partie tomu miała stanowić analiza argumentu kinetycznego. Praca nad tym argumentem została przerwana przez chorobę $\mathrm{w}$ listopadzie 1981 r. Dzięki wysiłkom grupy lekarskiej kierowanej przez prof. A. Szczeklika w Klinice Intensywnej Terapii w Krakowie prof. Kłósak mógł jeszcze powrócić do pięciomiesięcznej pracy nad argumentem kinetycznym. W tym okresie między styczniem a majem 1982 r. wypracowany został przez niego nowy wariant argumentacji kinetycznej, który drukowany jest obecnie po raz pierwszy na łamach Analecta. Pracę niniejszą, przerwaną przez śmierć prof. Kłósaka 1 czerwca $1982 \mathrm{r}$. uzupełnił i przygotował do druku ks. doc. Józef Życiński.

1 ,Znak", 4 (1949) 392-401.

2 S. 398.

3 „Ateneum Kaplańskie”, r. XLII, t. 52 (1950) 185-197.

4 S. 186.

5 Por. s. $190-193$. 
Towarzystwa Teologicznego $\mathrm{w}$ dniu 28 lutego $1950 \mathrm{r}^{6}{ }^{\mathrm{W}}$ referacie tym Pietkun, zapominając zapewne o tym, co pisałem o dialektycznej koncepcji ruchu ${ }^{7}$, zarzucił mi, że wychodzę w mym rozumowaniu ,z diamatycznej interpretacji ruchu" ${ }^{8}$.

Obok Pietkuna zabrał w tym czasie głos Mieczysław Albert Krąpiec, który, nie wchodząc w szczegółową dyskusję z zajętym przeze mnie stanowiskiem, starał się $\mathrm{w}$ artykule Raz jeszcze o kinetycznym dowodzie istnienia Boga ${ }^{\circ}$ wykazać, że argumentacja z ruchu jest słuszna i posiada moc przekonywającą. Krąpiec podjął się obrony najbardziej rozpowszechnionego w kołach myślicieli katolickich wariantu argumentacji kinetycznej, który za punkt wyjścia bierze wszelką zmianę.

We wczesnych stadiach naszej rodzimej dyskusji nad wartością argumentacji kinetycznej zakwestionował jeszcze konieczność jej rewizji Jan Dorda. Jego rozprawa Złudne zarzuty $z$ fizyki przeciw dowodowi kinetycznemu na istnienie Boga (ss. 35), pojęta jako studium epistemologiczne, nie została ogłoszona drukiem, ale z jej treścią mogłem się zapoznać dzięki uprzejmości autora, który upoważnił mnie do jej wykorzystania przy nowym opracowaniu kontrowersyjnego tematu. Szczegółowo rozwinięte wywody tego autora, skierowane nie tylko przeciw mnie, zasługiwały na to, żeby je szerzej uwzględnić w ich zasadniczych tezach. Wziąłem je pod uwagę w cz. II mojej pracy $W$ poszukiwaniu Pierwszej Przyczyny ${ }^{10}$. Obecnie jeszcze raz do nich powracam, żeby je rozpatrzyć w świetle moich późniejszych przemyśleń.

Dorda starał się w swojej rozprawie wykazać, że nie można negatywnie ustosunkowywać się do argumentacji kinetycznej, odwołując się do tezy, że ruch jest nieodłączną własnością materii ${ }^{11}$. A nie można, weHer.

6 Por. napisane prizez Pietkuna sprawozdanie $\mathrm{z}$ tego referatu oraz $\mathrm{z}$ dyskusji, jaka miała po nim miejsce, w ,Collectanea Theollogica”, 21 (1950) 578-584.

7 Por. moje artykuły: Dialektyczna interpretacja ruchu (,Ateneum Kapłańskie”, r. XL, t. 48 (1948) 1-13) i Materializm dialektyczny. (,,Homo Dei", 18 (1949) 371-372) oraz prace pod tym samym tytułem, co drugi artykuł (Kraków 1948, 67-79). Pietkun nie zwrócił również uwagi na to, że Adam Schaff, który w pierwszym wydaniu Wstępu do teorii marksizmu (Warszawa 1947, 43) powoływał się w pierwszym rzędzie przy zblijaniu argumentacji za istnieniem Boga z ruchu na zasoby kinetycznej energili wewnątrzatomowej, mającej czynić zbędnym wsizelki impuls zewnętrizny dla uwarunkowania ruchu materii, w wydaniu czwartym wymienionej książki (Warszavia 1949) pominął myśl o kinetycznej energiii wewnątrizatomowej, jakłby ta myśl wprowadzala dysonans do jego wywodów, natomiast wysunął jako jedyną rację przeciw argumentacji za istnieniem Boga $z$ ruchu marksistowską tezę o walce przeciwieństw (por. s. 42 i 43 ).

- S. 579. - Pomijam wystąpienie Pietkun a w artykule Pozycja argumentu kinetycznego w ogólnym dowodzie na istnienie Boga, „Homo Dei”, 21 (1952) 67-73.

9 „Znak”, 5 (1950) 281-295. Por. jeszoze tegoż autora O prawne rozumienie kinetycznego dowodu na istnienie Boga $u$ św. Tomasza, ,Polonia Sacra”, 6 (19531954) $97-113$.

10 S. $13-19$.

11 Według Dordy ta teza wyrażająca myśl, że wszysitko w abręibie rzeczywistości materialnej musi być w nieustannym ruchu, ,oznacza, że odległość jalki.chkolwiek 
dług niego dlatego, że (1) nie jest prawdą, iż ruch ,wynika bez reszty z działania sił, względnie z istnienia i zachowania energii", (2) równanie Einsteina, które wiąże energię kinetyczną z przyrostem masy spoczynkowej $m_{o}$ ciała poruszającego się z prędkością $v$, nie jest dowodem na nieodłączność ruchu od materii, i (3) istnieje możliwość spoczynku nawet całego kosmosu materialnego przez czas skończony.

„Energia - pisał Dorda - nawet jeśli się ją uzna za przynależną do istoty materii, nie pokrywa się z pojęciem przyczyny sprawczej ruchu. To samo dotyczy sił fizycznych. Ich «wpływ» na ruch jest czymś zupełnie obcym pojęciu przyczyn sprawczych, bo nie jest niczym więcej, jak związkiem funkcyjnym, który doskonale podpada pod arystotelesowskie pojęcie przyczyny formalnej, materialnej, lub obu razem". Tego rodzaju ujęcie ,wpływu” energii i sił fizycznych na ruch po linii przyczynowości formalnej i materialnej narzuca się, według Dordy, tym bardziej, że - jak sądził ten autor - energia i siły fizyczne są to entia rationis, które mają tylko pewną podstawę w takich rzeczywistościach, jak długość, czas, masa lub jeszcze prędkość.

Negatywne stanowisko Dordy wobec koncepcji sił fizycznych jako przyczyn sprawczych ruchu znajduje więc swe uzasadnienie w tym, że, w jego mniemaniu, siły fizyczne ,nie są [...] niczym więcej, jak przetlumaczeniem na język różniczkowy zdania: «Ruch przebiega w ten a w ten sposób». Przypadki, przy których mówi się o stwarzaniu siły przez ruch, np. siły grawitacyjnej, siły tarcia lub siły wymiany, tłumaczącej przyciąganie, jakie zachodzi w jądrach atomów między protonami a neutronami, dowodzą, zdaniem Dordy, że ,fizycy pojmują zawsze wpływ siły jako przyczynowość formalną".

Podobnie jak siły fizyczne pojął mój oponent energię. Potraktował ją jako ,produkt umysłowy syntezy” takich co najmniej trzech pierwotnych form bytu jak ilość, jakość i działanie. Energia stanowiła więc dla Dordy ens rationis ,z podkładem w rzeczach, (który dość trywialnie może okazać się tylko ruchem)". Ma to być przecież ,tylko osobliwa miara ruchu i jego możliwości”. Przy takim rozumieniu energii ,zasada zachowania energii $\mathrm{z}$ wyobrażeniem magazynowania i przenoszenia energii z cia-

dwóch punktów materialnych nigdy nie jest stała przez czas skończony. Zachowując stanowisko teorii względności o braku uprzywilejowanego układu współrzędnych, powyższe twierdzenie aznacza, że któnykolwiek punkt materialny w świecie weźmiemy za układ adniesienia, nie może istnieć ani jedna para punktów materialnych, mających w tym układzie odniesienia prędkość jednakową. Wizajemna bowiem odległość tych dwu punktów byłaby trwale niezmienna, co pociąga za sobą, że gdy w jednym z nich umieścimy układ odniesienia, drugi punkt będzie w nim trwale spoczywać wbrew założeniu, że «wsizystko jest w nieustannym ruchu». Powyższe więc założenie jest równoważne z twierdzeniem: Nie jest możliwe, aby dwie cząstki miały tę samą prędkość przez ozas skończony. W uogólnionej teorii względności będzie nadto równoważne z twiendzeniem: Niemożliwe jest isitnienie dwóch cząstek, opatrzonych jakimkolwiek ruchem identyaznym”. 
la w ciało jest syntetycznym, myślow y m schematem warunków odbywania się i przekazywania ruchu”, ,oraz zmian w nim równoważnych”. „Powiedzenie zatem, że ruch rodzi się z energii i z zasady jej zachowania, jest równoznaczne - utrzymywał Dorda - z powiedzeniem: "Ruch rodzi się z zastosowania doń pewnego sposobu mierzenia i mówienia o nim».

„Możliwość” ruchu aktualnego nie jest, według Dordy, żadną arystotelesowską potentia activa. „Na tę «możliwość» ruchu aktualnego czytamy w jego rozprawie - składa się bezwładność (w uogólnieniu Einsteinowskim) oraz zakrzywienie przestrzeni przez obecność mas, czyli po prostu przestrzenny rozkład mas, lub - jak kto woli - przestrzenna struktura układu ciał. (...) Czyli po staremu: quidquid movetur, ab alio movetur - lub z ukłonem w stronę bezwładności - ab alio motum est" ${ }^{12}$. Wszak w materii, której całkowita bezwładność ukazuje się, zdaniem Dordy, po pracach Einsteina w sposób bardziej bezwzględny niż ukazywała się w czasach Tomasza z Akwinu, „możliwość” ruchu przeprowadza się w aktualność tylko ruchem już istniejącym. Wobec tego ,za jedynie poprawny pogląd na przyczynowość fizyczną należy uznać - według Dordy - zdanie, że przyczyną zmiany jest inna zmiana" ${ }^{13}$. Za takim pojmowaniem genezy wszelkiej zmiany mają przemawiać nie tylko osiągnięcia Einsteina, ale i reguła Le Châteliera-Browna, która określa kierunek zmian ilościowych parametrów układu, wywołanych działaniem czynnika zewnętrznego.

Rozumowanie, które chce wyprowadzić tezę o nieodłączności ruchu od materii z równania Einsteina o równoważności masy bezwładnej i energii, Dorda przedstawił sobie w ten sposób: „Ponieważ masa jest z jednej strony nieodłączną właściwością materii, a z drugiej strony nieodłączną właściwością energii kinetycznej, to energia kinetyczna (ruch aktualny) jest nieodłączną właściwością materii. Co więcej jeszcze, zjawiska materializacji energii kinetycznej światła i dematerializacji masy spoczynkowej cząstek w energię kinetyczną światła podsuwają wniosek, że masa spoczynkowa jest w jakiś sposób utajoną energią kinetyczną światła, jeśli zmienia się w fotony. Innymi słowy: między masą spoczynkową a ruchową nie zachodzi istotna różnica; a ponieważ masa ruchowa jest rów-

12 „Dawny sposób myślenia o siłach, jako o przyczynach wywolujących ruch pisał Dorda - okazuje się po Einsteinie myśleniem bezkrytycznym. Jeśli w układzie materialnym zachodzą zmiany, przegrupowania ciał, czy energii, czy innych parametrów, jest rzeczą nielogiczną przypisywać te zmiany siłom wewnętrznym układu, czyli więzom. Cokolwiek uważać będziemy za więzy, doznaje to również przemiany, i mówić o nowym układzie więzów (sił) znaczy tyle tylko, co mówić innym językiem o zachodzących w układzie ruchach i przemianach".

13 Dorda sądził, że nie można mu zarzucać wznawiania tezy Mikołaja Malebranche'a. „Nie przeczymy - pisał - że ciała działają, a tylko przeczymy, że działają za pomocą sił. Działanie ciał jest uwarunkowane tylko posiadanym ruchem". 
noważna energii kinetycznej, czyli ruchowi, z drugiej zaś strony materia ma zawsze masę, ruch jest nieodłączny od materii".

Badając wartość tego rozumowania pod względem merytorycznym Dorda doszedł do przeświadczenia, że jest ono nieprzekonywające, gdyż nie jest prawdą, że między masą spoczynkową a ruchową nie zachodzi w przypadku prędkości podświetlnych istotna różnica. Ponieważ dla Dordy masa spoczynkowa i ruch były realnościami, zaś w przyroście ruchowym masy spoczynkowej, będącym dla prędkości podświetlnych czymś względnym, dopatrywał się on bytu rozumowego, znajdującego oparcie w wymienionych dopiero co realnościach, dlatego różnica między masa spoczynkową a ruchową przedstawiła mu się jako różnica bytu realnego oraz cechy absolutnej ciał materialnych i bytu pomyślanego oraz cechy relatywnej, mającej oparcie w zdolności do stawiania biernego oporu. Biorąc pod uwagę tę różnicę, Dorda sądził, że jest rzeczą wykluczoną, by przy masie spoczynkowej mogło chodzić o jakiś ,,zamaskowany w niej udział ruchu aktualnego". "Masa spoczynkowa - twierdził ten autor jest bez reszty tylko moż n oś c i ą ruchu".

Błędność tezy o nieodłączności ruchu od materii starał się jeszcze Dorda dowieść wykazując, że prawa fizyki pozwalają mówić o teoretycznej możliwości spoczynku przez czas skończony jakiejś elementarnej cząstki materii bez względu na to, czy kosmos materialny składa się ze skończonej czy nieskończonej liczby tych cząstek. Dorda utrzymywał także, że daje się bez sprzeczności pomyśleć nawet bezruch całego wszechświata materialnego ${ }^{14} \mathrm{w}$ przypadku specjalnego rozkładu protonów i elektronów w regularnej sieci sześciennej.

,Załóżmy - pisal nasz autor - że dla natury protonów i negatonów jest rzecż obojętną, czy ilość ich w świecie jest skończona, czy nieskończona. W tym drugim przypuszczeniu możliwy jest wśród innych rozkładów przestrzennych także i taki rozkład, że w regularnej sieci sześciennej ustawimy w węzłach sieci, czyli w narożach sześcianów elementarnych, protony i negatony $\mathrm{z}$ dołączonym neutrinem, a to w taki sposób, że między dwoma węzłami, obsadzonymi przez protony, znajduje się węzeł $\mathrm{z}$ negatonem i neutrinem [...].

W takiej nieograniczenie rozległej sieci z nabojami na przemian dodatnimi i ujemnymi, ustawionymi w węzłach, panuje doskonała symetria i równowaga sił, działających na każdą cząstkę, umieszczoną dokładnie w punkcie węzłowym, byle wszystkie cząstki w sieci spełniały ten sam

14 Uwzględniając stosunek tej możliwości do teorii względności Dorda utrzymywał, ,że w pojęciu pows zechnego spoczynku wszystkich ciał nie ma logicznych sprzeczności z zasadą dowolności układów spółrzędnych. Jeśli bowiem panowałby powszechny spoczynek, to znaczy niezmienna odległość pomiędzy ciałami, to gdziekolwiek umieścimy układ spółrzędnych, stwierdzimy niezmienność odleglości". 
warunek. Suma więc geometryczna sił, przyłożonych do każdego punktu materialnego $\mathrm{w}$ tej sieci, jest zerem.

Nie jest kwestionowane, że każda cząstka, choćby ruch był nieodłączny od materii, może posiadać prędkość c h w ilo w ą zero. Taką chwilową prędkość zerową spotykamy w punktach zwrotnych w ruchu wahadłowym. Nie widać powodu, ani prawa fizyki, które by wykluczało dla wszystkich wyżej wymienionych cząstek nieskończonego świata posiadanie chwilowej prędkości zerowej w tej właśnie chwili, kiedy ułożyły się w sieć regularnych sześcianów. Otóż na mocy doskonałej symetrii i równowagi sił $\mathrm{w}$ tej sieci nie istnieje siła, która by tę prędkość zerową zmieniła.

Jeśli wbrew Eddingtonowi założymy, że obojętną jest rzeczą dla cząstek elementarnych, czy istnieją w ilości skończonej, czy nieskończonej, to możliwość trwałego bezruchu, ujawniona w tym jedynym wypadku regularnej sieci nieograniczonej utrzymuje się dla materii stale; nie może bowiem być, aby coś sprzecznego $z$ istotą rzeczy kiedykolwiek się ujawniło ${ }^{15}$. Zdolność więc do bezruchu, ujawniona w tym specjalnym przypadku, okazuje, że ruch jest tylko przypadłością, przygodnie związaną z materią, nie zaś właściwością nieodłączną" ${ }^{16}$.

Przy takim pojmowaniu stosunku ruchu do materii argumentacja za istnieniem pierwszej przyczyny ruchu przedstawiła się Dordzie jako "osobliwy przypadek dowodu ex contingentia”. Nie rozpracowując tego „dowodu”, Dorda zadowolił się tylko uwagą, że w tym „dowodzie” staje się rzeczą niepotrzebną wykluczanie szeregu nieskończonego motorów, gdyż „przygodność ruchu obejmuje świat materialny bez względu na jego skończoność czy nieskończoność". Dodał jeszcze Dorda, że nie chodziło $\mathrm{mu}$ o przeanalizowanie podniesionej $\mathrm{w}$ jednej $\mathrm{z}$ moich prac trudności dotyczącej utożsamienia pierwszego motoru z Bogiem.

2. Sądzę, że moi pierwsi krytycy, Pietkun, Krąpiec i Dorda, mieli

15 Dorda wziął jesizcze pod uwagę inny przypadek możliwości bezruchu materii. „Da się pomyśleć - pisał ten autor - na mocy tego, co już dziś wiemy o ewolucji gwiazd ad olbrzymów do karłów, takie upakowanie materialnych cząstek po wypromieniowaniu wszystkich zasobów swobodnej energii, że w tym tłoku nie będzie już ruchu z powodu braku miejsca na ruch".

16 Uwzględniając ten sens tezy o nieodłączności ruchu od materii, o jakim była mowa w przyp. 11, Dorda pisał: „Pomijając już kontrangument o identycznej prędkości światła dla wszystkich fotonów, co powiemy o ruchu wiązki negatonów, wydobytych $z$ katody $w$ tych samych warunkach i przyspiesizonylch tym samym spadkiem potencjału?! - Inny fakt: Natężenie emisji pewnej ściśle określonej fali światła zależy ad ilości identycznych periodycznych ruchów w atomach, biorących równocześnie udział w emisji. Jeśli ma zachować sens przypisywanie takiej samej budowy analogicznym atomom, fizyka nie może zrezygnować z założenia zarórwno ¿dentyczności i ostrości poziomów energetycznych, jak i z wynikających stąd tożsamości ruchów w takich samych atomach, równocześnie emitujących. - Nienaukową więc rzeczą jest mówić o trwałym ruchu, a odmawiać możności trwałego spoczynku materiij". 
tylko część słuszności. Jest prawdą, że filozoficzne zagadnienie istnienia pierwszego motoru całkowicie nieruchomego, będącego Bogiem, nie stało się zagadnieniem bezprzedmiotowym przy akceptacji wysuwanego obecnie przyrodniczego obrazu świata. Podejmując współczesne poglądy przyrodnicze nie jesteśmy jednak zmuszeni do pytania się w płaszczyźnie poznania filozoficznego o istnienie jednego pierwszego motoru nieruchomego, który byłby bezpośrednim sprawcą fizycznego ruchu lokalnego. Możemy wszakże podjąć dociekania, czy dla ostatecznego wytłumaczenia faktu ruchu lokalnego materii nie trzeba przyjąc istnienia jakiegoś jednego pierwszego motoru całkowicie nieruchomego, który byłby pośrednim sprawcą tego ruchu, jeśliby wyposażył materię w uzdolnienie do jego dokonywania, i czy tak rozumiany pierwszy motor nie utożsamia się z Bogiem. Wydaje się więc, że argumentacja kinetyczna, o ile bazuje na fizycznym ruchu lokalnym, ostała się ni e jako s a modzielna argumentacja, ale jako wariant argumentacji z przyczynowości sprawczeji z przygodności rzeczy, dokładniej, że można ją wprowadzić tylko w następstwie ograniczenia argumentacji z przyczynowości sprawczej i z przygodności rzeczy do fizycznego ruchu lokalnego.

Oto, jak bardziej szczegółowo przedstawiło mi się zagadnienie istnienia pierwszego motoru całkowicie nieruchomego:

Z a sadę ruchu wyrażającą myśl, że wszystko, co się porusza jest poruszane przez coś innego (omne quod movetur, ab alio movetur), tę podstawową, pierwszą tezę kosmologiczną argumentacji kinetycznej, należy i obecnie uznać za bezwzględnie prawdziwą w odniesieniu do obiektów fizycznych. Wszak według zasady ruchu byt podzielony musi być koniecznie poruszany przez coś innego w tym jedynie znaczeniu, że jego ruch nie daje się urzeczywistnić w niezależności od jego części składowych. Gdy natomiast idzie o poruszanie go z zewnątrz przez odrębne od niego indywiduum, to tego rodzaju uaktywnianie może mieć miejsce, ale nie jest konieczne do tego, żeby można było powiedzieć, iż dany byt złożony jest poruszany przez coś innego. Chociaż więc Tomasz z Akwinu sądził, że ciała są per se nieruchome, a tylko są zdolne do ruchu, do którego bywają wprawiane z zewnątrz, to jednak w samej zasadzie ruchu wziętej według jej obiektywnego sensu, nie można się dopatrzyć takiego założenia. Zasada ruchu daje się, bez naruszania jej treści, pogodzić z tezą, że ruch mechaniczny jest stałą, choć zacieśnioną do pewnych układów odniesienia, własnością materii, i że materia w swym całokształcie znajduje się $\mathrm{w}$ ruchu mechanicznym per se, dzięki własnym siłom czy energii. Przecież wówczas, gdy zgodzimy się na tę tezę, możemy dalej twierdzić za Tomaszem, że żadne 
ciało nie może poruszać samo siebie, o ile stanowi pewną całość, niezależnie od swych części.

Nie powinno więc dziwić, że mimo pozytywnego ustosunkowania się do zasady ruchu, nie możemy $w$ ten sam sposób odnosić się do całości argumentacji kinetycznej, bazującej na fizycznym ruchu lokalnym. Ze względu na to, że powszechność dynamicznego aspektu rzeczywistości fizycznej - która wbrew wywodiom Dordy, a zgodnie z sugestiami przedstawionymi przez Białobrzeskiego $\mathrm{w}$ dziele Podstawy poznawcze fizyki świata atomowego ${ }^{17}$ narzuca się przy konkretnej, filozoficznej interpretacji tego, co wiemy o sile mechanicznej $i$ energii prowadzi nas do przeświadczenia, iż cały wszechświat ciał porusza się, gdy idzie o bliższe źródło jego ruchu, dzięki własnym, immanentnym siłom, musimy powiedzieć, że obecnie szukanie pozaświatowego, bezpośredniego sprawcy ruchu materii nie posiada dostatecznego uzasadnienia przedmiotowego. Nie przyjmujemy przecież, żeby ciała nieożywione były szeregami tak kolejno wprawiane w ruch od zewnątrz, jak to za Stagirytą utrzymywał Tomasz z Akwinu, który sądził, że pierwiastki (elementa) w rozumieniu arystotelesowskim podlegają kinetycznemu oddziaływaniu ciał niebieskich, z tych znów niższe ciała są poruszane przez wyższe, a ostatecznie zapoczątkowaniem wszelkiego ruchu w obrębie przyrody nieożywionej jest jeden ciągły ruch „,pierwszego nieba", mający wywodzić się od jakiejś rozumnej substancji (ab aliqua intellectuali substantia), uzdolnionej do akcji motorycznej przez wzięcie Boga za przedmiot swych pragnień. Obecnie, jak to już zaznaczyłem wyżej, możemy pytać się tylko o to, czy dla ostatecznego wytłumaczenia fizycznego ruchu lokalnego $\mathrm{w}$ ramach przyrody nieożywionej jesteśmy zmuszeni przyjąć istnienie jednego pozaświatowego, p o śr e d n i e g o motoru całkowicie nieruchomego, od którego byty materialne posiadałyby swe uzdolnienia do ruchu. Przyjęcie istnienia tego rodzaju motoru, który utożsamiałby się z Bogiem, nie nastręcza trudności, gdy zwrócimy uwagę na to, że siły ruchowe rzeczywistości fizycznej mają, jak wszystko w otaczającym nas kosmosie, charakter czegoś przygodne go, niek on i ecznego, i że wskutek tego ich istnienie może znaleźć ostateczne wytłumaczenie $\mathrm{w}$ istnieniu bytu koniecznego, będącego Bogiem.

Obecnie już nie mogę powtórzyć wiele $\mathrm{z}$ tego, co napisałem $\mathrm{w}$ artykule Kinetyczny dowód istnienia Boga wobec nowych zarzutów: „Jest prawdą, że dla wytłumaczenia ruchu materii nie potrzebujemy uciekać się do Boga jako pierwszego motoru. Motyw takiego motoru był motywem zbędnej ingerencji nadzwyczajnego Boga. Gdy jednak ruch materii możemy sobie wytłumaczyć działaniem sił własnych materii, to istnienie

17 S. $291-294$. 
materii lub może istnienie wolnej energii, która przez zmniejszenie szybkości swych ruchów doprowadziła do pojawienia się materii, stanie się dla nas zrozumiała dopiero wówczas, gdy założymy istnienie Boga stwórcy. Nie możemy [...] przyjmować wieczności materii wraz ze wszystkimi jej ruchami, bo taka koncepcja jest nie do przyjęcia dla logicznie myślącego umysłu. Jeżeli istnienie materii wyraża się $\mathrm{w}$ czasie, to $\mathrm{w}$ takim razie materia nie może istnieć odwiecznie, lecz musi mieć początek w czasie, bo każdy odcinek czasu, jaki zdołamy wyodrębnić, ma charakter czegoś skończonego, a ze sumowania się skończonych odcinków czasu może powstać tylko skończony okres trwania sukcesywnego. Gdy znów przyjmie się, że materia lub jakaś pierwotna postać energii musiała mieć początek w czasie, wówczas będziemy musieli przyznać, że istnienie tej materii lub energii jest zrozumiałe tylko przy założeniu działania istoty tak potężnej, że ją tylko z Bogiem można utożsamić. Wszak jest nie do pomyślenia, żeby materia lub energia mogły same przez się przejść z niebytu do bytu. W ten sposób okazuje się, że [...] przyjęcie współczesnych poglądów na genezę ruchu materii nie zamyka przed naszą myślą drogi do Boga" ${ }^{18}$.

Tadeusz Wojciechowski lepiej zorientował się w uwzględnionych przeze mnie perspektywach, gdy w artykule Uwagi krytyczne o kinetycznym dowodzie istnienia Boga ${ }^{19}$ pisał, że, według mnie, ,ruch nie tłumaczy się bez reszty siłami wewnątrz świata, gdyż istnienie materii lub energii jest zrozumiałe tylko przez założenie istnienia Boga jako pierwszej przyczyny". Jest to ujęcie, które wymieniony autor starał się w ten sposób bliżej uzasadnić: „Ruch, jako przymiot ogólny materii, nie znajduje [...] swego wytłumaczenia $\mathrm{w}$ samej materii, gdyż ta, jako sama przygodna $\mathrm{w}$ istnieniu, jest niezdolną do obdarzenia siebie, przez siebie, tym przymiotem. Przyczyna sprawcza, która była przyczyną zaistnienia materii, jest przyczyną zaistnienia materii obdarzonej przymiotem ruchu. Myśl tę spróbuję przedstawić inaczej. Wyobraźmy sobie wszystkie ruchy konkretne jako elementy zbioru, który stanowi klasę wszystkich ruchów. Poszczególne ruchy przedstawiają się jako elementy a, b, c, d... itd. tej samej klasy. Otóż zaistnienie każdego poszczególnego elementu lub sumy poszczególnych elementów tej samej klasy, da się wytłumaczyć relacjami w obrębie całości. Natomiast ruch rozważany w swej naturze z założeniem, że jest przygodny, zaistnienia swego nie tłumaczy w sposób wystarczający relacjami w obrębie klasy ruchów, gdyż musiałby mocą swą własną przejść $\mathrm{z}$ nieistnienia do istnienia. Tymczasem nie działa to, czego jeszcze nie ma. Jeżelibyśmy przyjęli, że poszczególne elementy zbioru tłumaczą ca-

18 S. $400-401$.

19 ,Polonia Sacra”, 5 (1952) 317. 
łość ruchów, to w takim razie o elemencie musielibyśmy powiedzieć to samo, co poprzednio. Ruch rozważany w swej naturze jako przymiot materii nie jest wytłumaczalny sam przez się, gdyż jako przygodny nie tłumaczy swego przejścia $\mathrm{z}$ niebytu $\mathrm{w}$ byt. Dla urzeczywistnienia tego przejścia domaga się przyczyny" ${ }^{20}$.

Nietrudno zauważyć, że te wywody Wojciechowskiego narzucały $\mathrm{w}$ stosunku do mojego ujęcia $\mathrm{z}$ artykułu Kinetyczny dowód istnienia Boga wobec nowych zarzutów konieczność dalszej jeszcze precyzji czy raczej korektury. Wojciechowski, zasugerowany moim sformułowaniem, pisał: ,Jeżeli [...] wnioskujemy z ruchu, to dochodzimy do materii, której on jest przymiotem. Wnioskować przeto o Bogu z ruchu możemy właściwie pośrednio przez materię. A ta domaga się nie motoru, lecz pierwszej przyczyny przejścia z nieistnienia w istnienie. Możemy przyjąć, że Bóg stworzył materię obdarzoną ruchem, i mamy wtedy przyczynę sprawczą, a nie pierwszy poruszający motor" ${ }^{21}$. Tymczasem nie może ulegać wątpliwości, że Bóg pojęty jako stwórca materii obdarzonej ruchem jest także pierwszym sprawcą ruchu, a więc pierwszym motorem nieruchomym. Bóg w tym rozumieniu jest wpravdzie pośrednim tylko sprawcą ruchu, ale przecież w pojęciu pierwszego motoru nieruchomego nie mieści się koniecznie myśl o bezpośrednim zapoczątkowywaniu ruchu w kosmosie.

$\mathrm{Z}$ ideą Boga jako pośredniego sprawcy ruchu wystąpiłem jeszcze przed ukazaniem się artykułu Wojciechowskiego. Uczyniłem to w artykule Dialektyczne prawo ruchu materii ${ }^{22} \mathrm{i}$ wyrażoną $\mathrm{w}$ nim myśl uważam ostatecznie za słuszną. Podobne stanowisko zajął w naszej rodzimej literaturze tomistycznej Ignacy Różycki, który pisał w ten sposób mając na uwadze rozumowanie Tomasza z Akwinu z Sumy teologii: „Dowód św. Tomasza zachowuje [...] swoją ważność również wobec najnowszej fizyki, uważającej ruch za nieodłącznie związany $\mathrm{z}$ naturą materii. Sytuacja metafizyczna, jaką nam ten dowód odsłania, wygląda następująco: przyrodnik, a nawet i filozof, może na podstawie obserwacji i rozumowania dojść do wniosku, że ruch właściwy należy do struktury materii; metafizyk zaś, zastanawiający się nad ostateczną przyczyną wszystkiego, przy pomocy niniejszego dowodu dochodzi do wniosku, że nie sobie samej, ale Bogu zawdzięcza materia to, że ruch należy do jej struktury" ${ }^{23}$.

3. Chcąc zdobyć podstawę do ogarnięcia możliwie najszerszych horyzontów przy szczegółowym rozwinięciu intuicji, jakie nasunęły mi się przy pisaniu artykułu Dialektyczne prawo ruchu materii, opracowałem

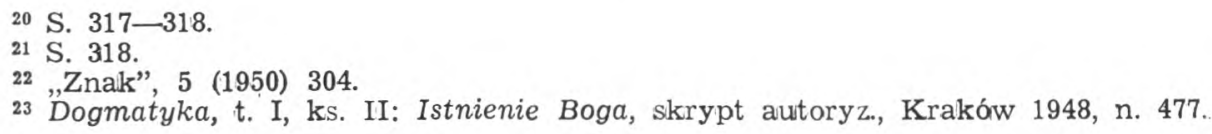


w studium $Z$ historii krytyki argumentu kinetycznego na istnienie Boga ${ }^{24}$ całość dyskusji, jaka, począwszy od Henryka z Gandawy i Jana Dunsa Szkota, toczyła się aż do naszych czasów w przedmiocie rozumowania ex motu. Po opracowaniu historii krytyki wskazanego rozumowania przystąpiłem do analizy tekstów Tomasza z Akwinu zaczynając od pierwszego wariantu argumentacji kinetycznej z Sum. c. Gent. (lib. I, c. 13) ${ }^{25}$. Krytyczny rozbiór tego wariantu nie był zbędnym trudem, bo choć już Jan Salamucha zajął się nim w rozprawie Dowód „ex motu” na istnienie Boga - Analiza logiczna argumentacji św. Tomasza $z$ Akwinu ${ }^{26}$, to jednak Salamusze chodziło głównie o rekonstrukcję logistyczną wywodów średniowiecznego myśliciela, a ponadto mało była przekonująca jego argumentacja przeciw tezie kosmologicznej, która głosi, że w serii bytów poruszających inne i poruszanych nie można posuwać się w nieskończoność.

Studiami $Z$ historii krytyki argumentu kinetycznego na istnienie Boga i Pierwszy argument kinetyczny na istnienie Boga z Sum. c. Gent., lib. I, s. 13, które, po wprowadzeniu do nich pewnych korektur i uzupełnien ${ }^{27}$, włączyłem do części II pracy $W$ poszukiwaniu Pierwszej Przyczyny, nie zdołałem zadowolić moich oponentów. Krąpiec, mając w dużej mierze na uwadze te dwa studia, pisał w artykule $O$ poprawne rozumienie kinetycznego dowodu na istnienie Boga u św. Tomasza: „Zagadnienie kinetycznego dowodu na istnienie Boga wzbudziło w ostatnich latach poważną dyskusję na łamach polskich czasopism naukowych i popularnych. Podkreślano rozmaite aspekty tego zagadnienia: historyczne, metafizyczne i przyrodnicze. Niestety jednak przy różnoaspektowym ujęciu

24 „Polonia Sacra”, 4 (1951) 117-154, 277-328.

25 "Polonia Sacra", 5 (1952) $89-131$; 6 (1953-1954) $1-45$.

28 "Collectanea Theologica”, 15 (1934) 53 -90.

27 Gdy idzie o tekst Wilhelma O ck ham a z Super quatuor libros Sententiarum subtilissimae questiones, Lugduni, per Johannem Trechsel alemanum MCCCCXCV, lib. I, dist. II, qu. $\mathrm{X}$, jaki uwzględniłem $\mathrm{w}$ pierwszym $\mathrm{z}$ wymienionych studiów (s. 281, przyp. 11), to w tym tekście jest mowa o przyczynach podporządkowanych kolejno jedna drugiej per accidens, a nie per se. Stąd też po zauważeniu tego nie mogłem już utrzymywać, że Ockham przez swoje wywody zakwestionował implicite drugie kosmologiczne założenie argumentacji kinetycznej, jak napisałem w pierwszej wersji historii jej krytki (s. cyt.). Mogłem tylko twierdzić, że venerabilis inceptor podważał prawdziwość drugiej tezy kosmologicznej w umyśle tych, którzy, jak autor Centiloquium theologicum, nie rozróżniali między przyczynami podporządkowanymi sobie istotnie i przypadkowo.

Studium o pierwszym wariancie argumentacji kinetycznej z Sum. c. Gent. włączyłem do części II książki W poszukiwaniu Pierwszej Przyczyny po częściowym jego przepracowaniu, przy którym uwzględniłem stanowisko Różyckiego (dz. cyt., t. I, ks. II, nr 463-478), Alberta Mitterera (Der Gottesbeweis aus der Bewegung nach Thomas von Aquin und nach Papst Pius XII, w: Theologische Fragen der Gegenwart, Festgabe für Kardinal Theodor Innitzer, Wien 1952, 49-59), Jakuba Maritaina (Approches de Dieu, Paris 1953, 33-42), Krapca (O poprawne rozumienie kinetycznego dowodu na istnienie Boga u św. Tomasza, 1. c.) i Dordy (cyit. maszynopis). 
problemu $\mathrm{u}$ niektórych autorów nastąpiły pewne pomieszania aspektu metafizycznego z przyrodniczym; a także omówienie historii kinetycznego dowodu wzięte $\mathrm{w}$ oderwaniu od podstaw doktrynalnych analizowanych systemów niewiele przyczyniło się do zrozumienia zagadnienia. Mogło więc powstać pewne zamieszanie w umysłach tych, którzy interesowali się i śledzili tok rozumowania przedstawiony w rozmaitych publikacjach" ${ }^{28}$.

Osoby trzecie będą mogły bardziej bezstronnie ocenić czy i w jakiej mierze surowa krytyka Krąpca jest słuszna w stosunku do moich studiów zamieszczonych w krakowskim kwartalniku „Polonia Sacra”, i czy rzeczywiście pod wpływem tych studiów „mogło [...] powstać pewne zamieszanie w umysłach tych, którzy interesowali się i śledzili" rozbudzoną u nas dyskusję nad argumentacją kinetyczną.

Nie uważając za skończoną dyskusję, jaka się u nas toczyła do r. 1957 w przedmiocie wartości tradycyjnych form argumentacji kinetycznej, podejmuję ją w niniejszym dziele raz jeszcze, uwzględniając refleksje, jakie nasunęły mi się później w reakcji na nowe głosy sprzeciwu, wyrażone $\mathrm{w}$ różnych artykułach ${ }^{29}$. Prócz nich chciałbym specjalnie rozpatrzyć wypowiedzi fizyków i filozofów dotyczące punktu wyjścia kinetycznej argumentacji, jakie zostały przedstawione w pierwszym dniu na sympozjum filozoficznym, które odbyło się w Krakowie w arcybiskupiej rezydencji Kard. Karola Wojtyły w dniach $10-11$ stycznia 1968 r. ${ }^{80}$ Licząc sie $\mathrm{z}$ nowym materiałem krytycznym $\mathrm{w}$ tej mierze, $\mathrm{w}$ jakiej on na to

28 S. 97.

29 J. Dorda, Błędy $w$ krytyce dowodu kinetycznego $w$ teodycei, "Homo Dei", 29 (1960) 517-524; Id., Pewność czy ryzyko?, „Znak” 12 (1960) 1004-1006; Z. J. $\mathrm{Zdy} \mathrm{bicka,} \mathrm{Charakter} \mathrm{rozumowania} \mathrm{występujacego} w$ Tomaszowym dowodzie kinetycznym istnienia Boga, „Znak”, 13 (1961) 1482-1499; id., Naukowy obraz świata materialnego a problem poznania istnienia Boga, „Zeszyty Naukowe KUL”, 11 (1968, nr 2) 25-26; S. Kamiński, Metodologiczna problematyka poznania Boga, "Studia Philosophiae Christianae", 1 (1965, $\mathrm{nr}$ 2) 298-299; id., Zagadnienia metodologiczne zwiqzane z filozofia Boga, w: Studia z filozofii Boga, praca zbiorawa pod red. B. Bejzego, Warszawa 1968, 70-71, 90, 100-103; M. A. K r ą p i e c, Metabicka, Poznawalność istnienia Boga, w: O Bogu $i$ o człowieku, praca zbiorowa pod red. B. Bejzego, Warszawa 1968, 70-71,90, 100-103; M. A. K r ą p i e c, Metafizyka $i$ problem Boga, w: Studia $z$ filozofii Boga, jak wyżej, 361-362; id., Filozofia i Bóg, w: O Bogu $i$ o człowieku, jak wyżej, 23-24, 39-42; S. Z i e m i a ńs k i, Arystotelesowska koncepcja ruchu jako punktu wyjścia dowodu kinetycznego, „Studia Philosophiae Christianae” 5 (1969, nr 2) 179-197; id., Zwiazek argumentu kinetycznego $z$ argumentem antropologicznym, tamże, 7 (1971, nr 2) 277-295; S. A dam czy k, Arystotelesowsko-tomistyczna zasada ruchu wobec wspótczesnych nauk przyrodniczych, „Rocznilki Filozoficzne”, 19 (1971, z. 3) 5-22; S. K ow a 1c zyk, Filozofia Boga, wyd. II, Lublin 1980, 73, 79-81; E. M or a w i e c, Nauki szczegótowe, filozofia a poznanie istnienia Boga; w: Aby poznać Boga $i$ człowieka, cz. $1,28-31$.

30 Zob. w sprawozdaniu Edmunda M orawc a Sympozjum filozoficzne poświęcone analizie punktu wyjścia kinetycznego $i$ teologicznego argumentu na istnienie Boga, zamieszczonym w ,Studia Philosophiae Christianae”, 4 (1968, nr 2), s.s. 225251. 
zasługuje, przeanalizuję jeszcze nie rozpatrywane dotąd przeze mnie teksty Tomasza z Akwinu z zakresu wskazanej argumentacji, a więc drugi jej wariant z Sum. c. Gent., lib. I, cap. 13, oraz ujęcie z Sum. theol., I, qu. II, a. 3, i Compendium theologiae, pars prima, cap. III-XXXIV.

Uprzedzając rezultaty analizy tych tekstów chciałbym zaznaczyć, że obecnie nie utrzymuję, jak to czyniłem dawniej, iż zasadniczy zrąb klasycznej dla Akwinaty argumentacji kinetycznej (a więc z wyłączeniem drugiego jej wariantu z Sum. c. Gent.) daje się zmodernizować tylko w ten sposób, że się ją uzgodni ze współczesnym przyrodniczym i filozoficznym obrazem świata. Rozmyślając nad argumentacją kinetyczną z Sumy teologii zauważyłem, że gdy ją sprowadzimy do jej zasadniczej myśli, możemy ją oderwać od jakiegokolwiek przyrodniczego i filozoficznego obrazu świata, kiedy za punkt wyjścia naszych wywodów weźmiemy nie ruch fizyczny, lecz jakąkolwiek zmianę, której genezę będziemy starali się ostatecznie wytłumaczyć przy posłużeniu się pojęciami możności i aktu. Dostarczając możliwość takiej formy argumentacji kinetycznej, której charakter interdyscyplinarny ogranicza się do spożytkowania w filozofii Boga metafizycznej teorii możności i aktu oraz metafizycznej zasady racji bytu, nie uważam tylko, żeby to była jedyna jej forma współczesna.

Spostrzeżenie dokonane w trakcie lektury Sumy teologii wnosi, jak można sądzić, nowy wymiar do moich dotychczasowych refleksyj nad Tomaszowymi wariantami argumentacji kinetycznej, wiązanych z osiągnięciami współczesnej fizyki i filozofii przyrody. A gdy idzie o historię wielowiekowej krytyki argumentacji kinetycznej, to ją pojmuję w obecnym tomie jako pełniejsze rozwinięcie interpretacji i zastrzeżeń różnych autorów, o których wspominam przy analizie i ocenie Tomaszowych form rozumowania. Tym się tłumaczy, że wskazaną historię zamieszczam po krytycznym omówieniu wariantów kinetycznej argumentacji Akwinaty.

\section{ANALIZA I PRÓBA OCENY TOMASZOWYCH FORM ARGUMENTACJI KINETYCZNEJ}

W Summa contra Gentiles, lib. I, c. 13, znajdują się dwa warianty argumentacji kinetycznej za istnieniem Boga. Pierwszy wariant zaczyna się od słów: „Quarum prima talis est”, a kończy słowami „qua probat Aristoteles esse primum motorem immobilem". Drugi wariant mieści się między zdaniami ,Secunda via talis est” i „Oportet igitur esse primum motorem separatum omnino immobilem, qui Deus est". Oba warianty argumentacji Tomasz podaje jako wywody sformułowane przez Arystotelesa, ale nie ulega wątpliwości, że sam je również przyjmuje. 
W niniejszym studium pomijam analizę pierwszego wariantu argumentacji z Sum. c. Gent., gdyż nadal przy jego ocenie podtrzymuję opinie, które przedstawiłem obszernie w 1957 r. w II części pracy $W$ poszukiwaniu Pierwszej Przyczyny. Podzielając zastrzeżenia, które w Die Gottesbeweise formułował przeciw argumentowi kinetycznemu ks. Franciszek Sawicki, sądzę, iż pierwszy z wymienionych argumentów nie stanowi obiektywnego usprawiedliwienia dla tych treści, które usiłowano uzasadniać przez odwołanie do niego w tradycyjnych interpretacjach. Refleksja nad brakami tego wariantu prowadzi do przeświadczenia, że pierwszy motor nieruchomy, pojęty w sposób najbardziej maksymalistyczny, nie musiałby być Bogiem, skoro ani nie musiałby być bytem a se, ani bytem koniecznym, ani bytem całkowicie niezmiennym, ani bytem nieskończenie doskonałym, ani ponadświatową istotą, ani wreszcie czymś jedynym. Mając na uwadze tak liczne braki I wariantu z Sum. c. Gent., chcę zatrzymać się bliżej nad przedstawionym w tym samym dziele drugim wariantem argumentacji kinetycznej.

\section{A. DRUGI WARIANT ARGUMENTACJI KINETYCZNEJ Z SUM. C. GENT. LIB. I, C. 13}

1. Druga wersja argumentacji kinetycznej Arystotelesa, podjęta w szerokim zakresie przez Tomasza z Akwinu, abejmuje d wie części. Pierwsza zmierza do wykazania, że istnieje jeden pierwszy motor, który nie jest poruszany z zewnątrz przez inny byt (aliquod primum quod non movetur ab aliquo exteriori). W drugiej znów części chodzi o udowodnienie, że ten motor jest całkowicie nieruchomy i oddzielony od innych bytów tak, że trzeba go uznać za B og a. Do tych wywodów Arystotelesa Tomasz dołącza swoje zastrzeżenia, które ograniczają dość wydatnie ich wartość.

Próba w pełni adekwatnego uchwycenia logicznej strony całokształtu pierwszej części drugiego wariantu argumentacji kinetycznej nie jest tak prosta, jak się zdawało, mimo że mamy już w tym względzie magistralną interpretację pochodzącą od Gilsona. Jako przedmiot dyskusji podam własną interpretację.

2. Baza wyjściowa rozpatrywanej obecnie argumentacji Stagiryty nie została wyraźnie określona. Niemniej jednak można, jak się zdaje, sądzić zasadnie, że chodzi w niej o $\mathrm{ruch}$ ciał i to o ich sam $\mathrm{ruch}$ lo$\mathrm{k}$ a ln y. Wszak argumentacja ta stanowi dodatkowe rozumowanie w porównaniu z pierwszą wersją argumentacji kinetycznej, a w jej ramach 
zmierza się najwyraźniej do ostatecznego wyjaśnienia genezy wskazanej dopiero co formy ruchu. Wprawdzie przy swych dość skomplikowanych wywodach drugi wariant argumentacji kinetycznej wykracza w pewnych przypadkach poza pojęcie ruchu lokalnego ciał, ale zapewne ten tylko ruch został uwzględniony u podstaw drogi myślowej wiodącej do pierwszego motoru nieruchomego, skoro w drugiej uwadze końcowej analizowanej przez nas argumentacji zostało powiedziane, że pierwszym bytem poruszanym jest „ciało niebieskie”.

Argumentacja Arystotelesa stanowi w swej pierwszej części dowód n i e w p rost. Myśliciel starożytny dochodzi bowiem do uznania istnienia pierwszego motoru, nie poruszanego przez coś innego z zewnątrz, wykazując, lub raczej starając się wykazać, że zdanie wyrażające myśl, iż każdy byt, który porusza inne byty, jest sam poruszany z zewnątrz (omne movens movetur), nie jest zdaniem prawdziwym ani per se, ani per accidens. $\mathrm{Z}$ tego bowiem, że to zdanie nie jest prawdziwe w żadnym $\mathrm{z}$ tych dwu sposobów, wynika, zdaniem Arystotelesa, że istnieje jeden pierwszy motor, który sam nie jest poruszany $z$ zewnątrz przez inny byt ${ }^{31}$.

Żeby zasygnalizowana problematyka stała się w pełni zrozumiała, trzeba zaznaczyć, że przy zdaniach prawdziwych per se i per accidens chodzi tylko pozornie o koncepcję gnoseologiczną $\mathrm{z}$ dziedziny teorii prawdy. Naprawde jest to, jak wynika z kontekstu, koncepcja on to lo g i c z$\mathrm{n}$ a. Arystotelesowi chodziło o rozwiązanie zagadnienia, które może okazać się zagadnieniem wykraczającym poza obręb filozofii przyrody, czy twierdzenie: ,każdy byt, który porusza inne byty, jest sam poruszany z zewnątrz" jest wyrazem jakiejś konieczności ontycznej, czegoś „obowiązującego” w każdym przypadku, czy też jest wyrazem przygodności, stanu rzeczy jedynie faktycznego, zachodzącego w pewnym tylko zakresie rzeczywistości. Jest to więc takie sformułowanie zagadnienia regresu w nieskończoność bytów poruszających inne i poruszanych, które ma prowadzić do wyjaśnienia czy ten regres jest ontycznie konieczny. Arystoteles opowiedział się za jego ontyczną nieskończonością. I choć jego argumentację można wyrazić w sposób zupełnie współczesny, bez uwzględniania podziału zdań na zdania prawdziwe per se i per accidens, to jednak, żeby nie odejść zbyt daleko od tekstu Arystotelesa i Tomasza z Akwinu, będziemy trzymali się tego podziału pamiętając tylko, że służy on do wyeksponowania przygodności, która występuje przy poruszaniu innych bytów w następstwie poruszania $\mathrm{z}$ zewnątrz ${ }^{32}$.

31 Por. Ar y tiotelesa Nat. auscult. lib. VIII, cap. V, s. 350 , w. 47-52, s. 351 , w. $1-7,23-40$.

${ }^{32} \mathrm{Na}$ występowanie w drugim wariancie argumentacji kinetycznej jakiejś 
3. Arystoteles dowodzi najpierw, że zdanie, według którego każdy byt poruszający inne byty, jest sam poruszany z zewnątrz, nie jest zdaniem prawdziwym per accidens, a następnie, że nie jest również zdaniem prawdziwym per se. Zachodzenie pierwszego stanu rzeczy uzasadnia na d w a różne sposoby.

P i e r ws y sposób: Jeżeliby przytoczone zdanie było prawdziwe per accidens, nie wyrażałoby nic koniecznego, a w następstwie tego byłoby możliwe ${ }^{33}$, że żaden byt, poruszający inne byty, nie byłby poruszany przez coś innego. Ale jeżeli jest tak, jak utrzymuje oponent, że jeśli czynnik poruszający nie jest poruszany przez coś innego, to nie porusza innych bytów - byłoby możliwe, że nic się nie porusza, gdyż jeżeli nic nie porusza czegoś drugiego, nic się nie porusza. To jednakże Arystoteles uważa za niemożliwe, żeby w jakimś momencie nie było żadnego ruchu. Wobec tego nie jest możliwe, żeby żaden byt, poruszający inne byty, sam nie był poruszany z zewnątrz, ponieważ z tego, co jest błędne per accidens (ex falso contingenti), nie wynika wniosek błędny, wyrażający coś bezwzględnie niemożliwego (falsum impossibile). Z tej też racji twierdzenie, że każdy czynnik poruszający jest poruszany przez inny byt, nie jest twierdzeniem prawdziwym per accidens ${ }^{34}$.

Drugi sposób: Jeżeliby zdanie, według którego każdy byt poruszający inne byty, jest sam poruszany przez coś innego, było prawdziwe per accidens, to właściwość poruszania innych bytów i właściwość, że się jest poruszanym przez inne byty, byłyby złączone $\mathrm{z}$ sobą per accidens. Lecz jeśli $\mathrm{z}$ dwu właściwości, których połączenie $\mathrm{z}$ sobą $\mathrm{w}$ danym bycie jest połączeniem per accidens, znajduje się jedną bez drugiej, to jest rzeczą prawdopodobną, że i tę drugą będzie można znaleźć bez pierwszej. I tak, jeżeli cecha białości i cecha bycia muzykiem łączą się per accidens u Sokratesa i u Platona, a u kogoś występuje ta druga cecha bez pierwszej, to jest rzeczą prawdopodobną, że w jakiejś innej

postaci problematyki kontyngencjalnej zwrócił już uwagę Salamucha, ale uczynił to bardzo ogólnikowo. Oto, co pisał w tym przedmiocie: ,W drugim dowodzie ex motu, podanym w Summa contra Gentiles, występują pewne koncepcje związane cum contingentia mundi. [...] Możliwą jest rzeczą, że ten drugi dowód ex motu został później przekształcony, uściślony i podany jako dowód ex contingentia w Sumie Teologicznej. (Dowód „ex motu” na istnienie Boga, 55). Jak się zdaje, Salamucha nie uświadomił sobie tego, że w swej trzeciej „drodze” Tomasz uwzględnił przygodność w aspekcie istnienia, a nie ruchu. Tym zapewne tłumaczy się sugestia Salamuchy o bliskim powiązaniu argumentacji kontyngencjalnej Tomasza z Sumy teologii z jego drugą wersją argumentacji kinetycznej.

${ }_{33} \mathrm{~W}$ ten sposób za Gilsonem (Le Thomisme - Introduction à la philosophie de saint Thomas d'Aquin, Paris $1947^{5}$ [na okładce r. 1948], 93) tłumacze wyrażenie: "contingens est”.

34 Końcowy wniosek przytoczonej argumentacji Gilson wyraził w słowach: ,la proposition: tout ce qui meut est mû, est vraie d'une vérité nécessaire, non par accident." (Dz. cyt., 1.c.) Tymczasem w argumentacji Arystotelesa, relacjonowanej przez Akwinatę, mamy: „Et sic haec propositio: Omne movens ab alio movetur, non fuit per accidens vera." 
jednostce będzie mogła wystąpić cecha białości bez cechy bycia muzykiem. Jeśliby więc właściwość poruszania innych bytów i właściwość, że się jest poruszanym przez inne byty, były złączone $\mathrm{z}$ sobą per accidens, to ponieważ ta druga cecha jest $\mathrm{w}$ pewnych przypadkach odizolowana od pierwszej, gdyż pewne byty są poruszane, a nie poruszają innych bytów, byłoby rzeczą prawdopodobną, że istnieje byt, który porusza inne byty, a sam nie jest poruszany ${ }^{35}$. [A jeżeli tak, to zdanie: ,każdy byt, który porusza inne byty, jest sam poruszany" nie jest zdaniem prawdziwym per accidens, gdyż przy takiej kwalifikacji dopuszczałoby coś, co jest z nim sprzeczne] ${ }^{36}$.

Tego znów, że zdanie: „każdy byt, poruszający inne byty, jest sam poruszany", nie jest zdaniem prawdziwym per se, dowodzi Arystoteles w następujący sposób: Jeżeliby to zdanie było zdaniem prawdziwym w podany sposób, to byt, o którym ono mówi, albo byłby poruszany według tego samego gatunku ruchu, według jakiego sam porusza inne byty, albo byłby poruszany według innego gatunku ruchu. Jeśli byłby poruszany według tego samego gatunku ruchu, mielibyśmy przypadek, w którym byt zniekształcający inne byty, sam byłby zniekształcany, albo przypadek, w którym byt dający innym zdrowie, sam byłby uzdrawiany, lub przypadek, w którym ktoś uczący innych sam byłby uczącym się, gdy idzie o tę samą wiedzę. To zaś jest niemożliwe, bo ponieważ uczący

35 Por. Tomasza Commentaria in octo libros Physicorum Aristotelis, lib. VIII, leat. IX, n. 8.

${ }_{36}$ Twiendzenie podane $\mathrm{w}$ nawiasie, które nie posiada formalnego odpowiednika w tekście Tomasza, stanowi - jak sądzę - logiczne zakończenie dowadu. Gilson inaczej zinterpretował rozumowanie Arystotelesa. Dla francuskiego mediewisty słowa Sumy filozoficznej: ,probabile est, quod movens inveniatur absque eo quod moveatur" były logicznym zakończeniem argumentacji. W następstwie tego napisal on w cyt. dziele: „La conclusion dépasse d'aidleurs ici le but que nous nous proposions d'atteindre. En démontrant que cette proposition: tout ce qui meut est mû, n'est pas vraie par accident, nous démonstrons du même coup que, si le rapport qui relie le moteur au mobile était accidentel, la possibilité, ou mieux la probabilité d’un premier mateur se trouveraient par là même établies." (S. 93). Jeżeli jednak przyjęta przeze mnie interpretacja byłaby adekwatna, nie można by powiedzieć z Gilsonem, że wskazane przezeń twierdzenie wykracza poza to, co jest celem argumentacji. Ws.zak to twiendzenie stanowiłoby tylko jej konieczne agniwo, gdyż dzięki niemu mógł Tomasz utrizymywać z Arystotelesem, że teza wyrażająca myśl, iż każdy byt, który porusza inne byty, jest sam poruszany, nie jest zdaniem prawdziwym $w$ sensie przypadłościowym. Ale jeżeliby tak było, nie moglibyśmy twierdzić, że Tomasz już dowiódł, że jest rzeczą możliwą, iż istnieje jeden byt poruszający inne byty, który sam nie jest poruszany. Akwinata ograniczałby się na razie do wniosku, że przyjęcie możliwości istnienia takiego bytu nie daje się pogodzić $w$ sposób bezsprzeczny $z$ uznawaniem badanej przez siebie tezy za zdanie prawdziwe per accidens. Gilson, trzymając się w Le. Thomisme (s. 93-94) dosłownego brzmienia tekstu Sumy filozoficznej, wyraził ozęściowo inaczej logiczną stronę argumentacji Tomaszowego Arystotelesa. Jego interpretacja nie obejmuje zdań, które zdają się być domyślne w kontekście argumentacji, jeśli ona ma być konsekwentna w swym całokształcie. A może ta argumentacja nie była konsekwentna w niektórych szczegółach? Wątpliwości w tym względzie nie umiem przezwyciężyć czytając tekst Sumy filozoficznej. 
z konieczności posiada pewną wiedzę a uczący się jej nie posiada, ten sam posiadałby coś i nie posiadał. [Wobec tego zdanie: ,każdy byt, poruszający inne byty, jest sam poruszany" nie jest zdaniem prawdziwym per se, jeżeli miałoby odnosić się do bytu, który jest poruszany według tego samego gatunku ruchu, według jakiego sam porusza inne byty]. Jeżeliby znów dany byt był poruszany według innego gatunku ruchu niż ten, według jakiego sam porusza, a więc jeśliby przy swym działaniu zniekształcającym na inne byty sam był poruszany ruchem lokalnym, a przy poruszaniu innych bytów ruchem lokalnym sam doznawałby wzrostu, i tak dalej, to ponieważ rodzaje i gatunki ruchu są w ilości skończonej, nie można by się wśród nich posuwać w nieskończoność. W konsekwencji zaś tego trzeba by przyjąć istnienie bytu, który poruszajac inne byty, sam nie jest poruszany. [Jednakowoż istnienia takiego bytu nie może przyjąć bez zaprzeczenia sobie ten, kto założył, że każdy byt, poruszający inne byty, jest sam poruszany. A jeżeli tak, to nie może również przyjąć, żeby rozpatrywane obecnie zdanie było prawdziwe per se, o ile odnosiłoby się do bytu, który byłby poruszany według innego gatunku ruchu niż ten, według jakiego porusza inne byty].

Jeżeliby znów ktoś, nie chcąc zatrzymać się na bycie nie poruszanym przez coś z zewnątrz, przyjął, że ruch po przejściu przez wszystkie swoje rodzaje i gatunki powróciłby w końcu do swej pierwszej postaci, a zatem gdyby na przykład założył, że byt poruszający inne byty ruchem lokalnym sam jest zniekształcany, a byt zniekształcający inne byty podlega wzrostowi, zaś podlegający wzrostowi porusza się ruchem lokalnym to i tak musiałby przyjąć, że dany byt pośrednio porusza według tego samego gatunku ruchu, według jakiego sam jest poruszany. To zaś jest niemożliwe do przyjęcia. Pozostaje więc niezmienny wniosek wyżej ustalony, że istnieje jeden pierwszy motor, który sam nie jest poruszany przez coś z zewnątrz. [Okazuje się bowiem, że zdanie: „każdy byt, który porusza inne byty, jest sam poruszany" nie jest prawdziwe per se również w ostatnio rozważanym przypadku] ${ }^{37}$.

4. Gdy z błędności tego zdania Arystoteles wyprowadził wiadomy nam wniosek, nie opowiedział się zaraz za tezą, że pierwszy motor nie poruszany przez coś z zewnątrz jest całkowicie nieruchom y i oddzielony od innych bytów. Chcąc przyznać mu te dwie właściwości, posłużył się dość długą argumentacją.

Zanim ją przytoczę, chciałbym zauważyć, że będąc rozwijaną w innym klimacie filozoficznym i przyrodniczym niż nasz, domaga się ona z naszej strony dość dużej cierpliwości, żeby się z nią aktualnie zapoznawać.

37 Tomasz pisze: „Moventia enim quae sunt apud nos, scilicet animalia, c u m sint corruptibilia, pars movens in eis movetur per accidens." Podkreślenie moje. 
Jej prześledzenie pozwala nam jednak uświadomić sobie, jakimi labiryntami szła nieraz myśl filozoficzna przeszłości, zanim uprościła się w naszych czasach przy bardziej adekwatnym przyrodniczym obrazie świata, gdy została sprowadzona do swych elementów treściowych naprawdę istotnych.

Po tej dygresji nad tekstem Akwinaty przechodzę do wywodów Arystotelesa. Jego zdaniem pierwszy motor, który nie jest poruszany z zewnątrz przez inny byt, albo jest pierwszym motorem całkowicie nieruchomym, albo jest pierwszym motorem, który porusza siebie. Jeżeliby był pierwszym motorem całkowicie nieruchomym, mielibyśmy już to, o co chodzi. Gdyby był pierwszym motorem, który porusza siebie, [a więc, gdyby był jakimś ciałem niebieskim] to i tak moglibyśmy dojść do wnios$\mathrm{ku}$, że istnieje inny pierwotny motor, który jest calkowicie nieruchomy. O bycie poruszającym siebie nie można by było bowiem powiedzieć, że, poruszając siebie całego, jest poruszany przez całego siebie (quod movens seipsum totum moveatur a toto), gdyż zawierałaby w sobie tę niemożliwość, że ktoś równocześnie uczyłby drugich i sam uczyłby się tego samego, czyli że coś byłoby równocześnie w możności i w akcie. Nie chcąc zakładać tej niemożliwości trzeba przyjąć, że w bycie, który by poruszał samego siebie, jedna tylko część byłaby czynnikiem poruszającym, a druga byłaby rzeczą poruszaną. Dochodzimy więc do wniosku, że istnieje coś, co porusza inne byty, a samo jest nieruchome.

Wracając jeszcze do koncepcji bytu poruszającego siebie, trzeba powiedzieć, że założenie, iż w tym bycie jedna tylko część byłaby czynnikiem poruszającym, a druga część byłaby rzeczą poruszaną, narzuca się w sposób konieczny z tego także powodu, że obie części nie mogą być poruszane tak, żeby jedna była poruszana przez drugą. Nie może być też tak, żeby jedna część poruszała samą siebie i poruszała drugą część, ani tak, żeby całość bytu poruszała swoją część, ani też tak, żeby część poruszała całość, gdyż w tym przypadku coś równocześnie poruszałoby $\mathrm{i}$ było poruszane według tego samego gatunku ruchu, a więc byłoby równocześnie w możności i akcie, a nadto całość nie miałaby racji do poruszania samej siebie w sobie, lecz w swej części.

Ponieważ w bytach poruszających siebie, jakimi u nas są zwierzęta, część będąca czynnikiem poruszającym, czyli dusza, chociaż jest nieruchoma per se, to jednak porusza się per accidens, Arystoteles wykazuje dalej, że część poruszająca w pierwszym bycie poruszającym siebie nie porusza się ani per se, ani per accidens. Argumentuje on tak:

W takich bytach poruszających siebie, jak zwierzęta, dlatego część poruszająca porusza się per accidens, że są to byty zniszczalne ${ }^{38}$. Lecz

38 Por. Arystoteles a Nat. auscult. lib. VIII, cap. V (pag. 352-353) i VI. 
byty zniszczalne i poruszające siebie domagają się istnienia pierwszego bytu poruszającego siebie, który by był bytem wiecznym, tzn. bytem utrzymującym się stale $\mathrm{w}$ tym samym stanie. Wobec tego musi istnieć jakiś motor immanentny dla danego bytu poruszającego siebie, który nie porusza się ani per se, ani per accidens.

To zaś, że musi istnieć jakiś byt wieczny poruszający siebie, jest rzeczą oczywistą. Wszak jeżeli ruch jest wieczny, to rodzenie się zniszczalnych jestestw poruszających siebie jest stałym zjawiskiem, które nie ma początku czasowego, ani nie będzie miało końca. Lecz przyczyną stałości tego zjawiska nie może być któreś ze zniszczalnych jestestw poruszających siebie, gdyż żadne $\mathrm{z}$ nich nie istnieje zawsze. Tą przyczyną nie mogą być również wskazane jestestwa wzięte razem już to dlatego, że ich liczba byłaby nieskończona, już to dlatego, że wszystkie naraz nie istnieją. Musi więc istnieć pewien byt poruszający siebie i mający trwałe istnienie, który jest przyczyną stałości zjawiska rodzenia się jestestw zniszczalnych, uzdolnionych do poruszania siebie. A motor wewnętrzny dla tego bytu nie będzie poruszał się ani per se, ani per accidens.

Trzeba jeszcze dodać, że żaden byt poruszający siebie nie poruszałby się wiecznie, gdyby motor, który stanowi jego część, poruszał się per se, albo per accidens. Lecz pierwszy byt poruszający siebie porusza się zawsze, gdyż w przeciwnym razie nie byłoby wiecznego ruchu, skoro wszelki inny ruch ma swą przyczynę w ruchu pierwszego bytu poruszającego siebie. Wobec tego pierwszy byt, poruszający siebie, porusza się dzięki swemu wewnętrznemu motorowi, który nie porusza się ani per se, ani per accidens.

Tego ostatniego dowodu nie podważa, zdaniem Arystotelesa, okoliczność, że motory niższych sfer niebieskich (motores inferiorum orbium) warunkują ruch wieczny (movent motum sempiternum), a jednak mówi się o nich, że poruszają się per accidens. Te bowiem motory poruszają się per accidens nie $\mathrm{z}$ racji ich samych, lecz z racji ciał, którymi kierują w zależności od ruchu wyższej sfery ${ }^{39}$.

Wykazawszy, że w pierwszym bycie, poruszającym siebie, istnieje pewna część, która nie jest poruszana ani per se, ani per accidens, stara się następnie Arystoteles udowodnić w swej Metafizyce, że dla tej części trzeba przyjąc nadrzędny motor całkowicie oddzielony od innych bytów, który jest Bogiem. Oto, w jaki sposób: Ponieważ wszelki byt, który porusza siebie, jest poruszany przez pożądanie (per appetitum), wobec tego motor, który jest częścią bytu poruszającego siebie, porusza ten byt

39 Por. niżej przypis 86 . 
na skutek pożądania określonego przedmiotu. Ten przedmiot jest od niego wyższy, jeżeli idzie o poruszanie, gdyż pożądanie jest w pewien sposób czynnikiem poruszającym i rzeczą poruszaną (movens motum), przedmiot zaś pożądania stanowi czynnik poruszający, który nie jest zupełnie poruszany. Musi więc istnieć pierwszy motor oddzielony od innych bytów i całkowicie nieruchomy, który jest Bogiem.

5. Zdaniem Tomasza z Akwinu druga Arystotelesowska argumentacja kinetyczna za istnieniem Boga nie jest w pełni zadowalająca. Posiada ona dwa braki.

Pierwszym brakiem jest okoliczność, że wychodzi ona $\mathrm{z}$ założenia faktu wieczności ruchu, które to założenie katolicy uważają za błędne. Jako powód negatywnego ustosunkowania się katolików do założenia faktu wieczności ruchu wymienia Tomasz tę trudność, że po uznaniu wieczności ruchu w odwiecznie istniejącym świecie istnienie Boga staje się rzeczą mniej oczywistą ${ }^{40}$. Najłatwiej można, według Akwinaty, wykazać istnienie Boga wtedy, gdy się założy, że świat miał początek w czasie. Jeżeli bowiem świat zaczął swe istnienie w pewnym momencie, jasną jest rzeczą, że musi mieć przyczynę, która by go powołała do istnienia, gdyż nic nie wyprowadza siebie z możności do aktu lub nieistnienia do istnienia.

Widoczne jest jednak, że - zdaniem Tomasza - błędność założenia wieczności ruchu nie przekreśla zasadniczych wniosków drugiej argumentacji kinetycznej Arystotelesa. Gdyby bowiem Tomasz uważał ją za całkowicie błędną, nie byłby jej pomieszczał wśród „dróg” mających zaprowadzić do przeświadczenia o istnieniu Boga.

Dalszym brakiem drugiego wariantu argumentacji kinetycznej Arystotelesa jest - według Tomasza - taka interpretacja pierwszego bytu poruszającego siebie, mianowicie ciała niebieskiego, z której to interpre-

40 Tak rozumiem stosunek zdania: „Ed ad hoc dicendum quod via efficacissima ad probandum Deum esse..." do zdania poprzedniego, w którym jest powiedziane, że katolicy uważają założenie o wieczności ruchu za błędne. Zdanie pierwsze w wydaniu Leonińskim ma postać: „Et ad hoc dicendum quod via efficacissima ad probandum Deum esse est ex suppositione aeternitatis mundi, qua posita, minus videtur esse manifestum quod Deus sit". Zdanie tak sformułowane zawiera zbyt jaskrawą sprzeczność, żeby nie przyjąć, iż zakradła się do niego na skutek przeoczenia pewna deformacja. Franciszek z Ferrary $w$ ten sposób ustala poprawne brzmienie tekstu: „Dicendum quod via efficacissima ad probandum Deum esse est ex suppositione novitatis mundi: non autem sic ex suppositione aeternitatis mundi, qua pasita minus videtur manifestum etc." Franciszek z Ferrary twierdzi, że taki tekst posiadają, ,correcti codices". (Zob. komentarz do roz. 13 księgi I Sumy filozoficznej $\mathrm{nr}$ XVIII w wyd. Leon.) Wydanie Leanińskie to twierdzenie zaopatruje uwagą ,qui haberent non invenimus” (s. 33), niemniej jednak tekst prizyęty przez Franciszka z Ferrary jest logicznie calkowicie uzasadniony i trudno rozumnie przypuścić, żeby Tomasz myślał inaczej, niż wyraża ten tekst, chociażby faktycznie przez przeoczenie napisal co innego. 
tacji wynika, że jest to ciało ożywione. Otóż na takie pojmowanie natury ciała niebieskiego - jak zauważył Tomasz — wielu się nie zgadza.

Tomasz sądził jednak, że nawet po odrzuceniu tezy animistycznej pozostaje nie naruszona konkluzja drugiej argumentacji kinetycznej, bo jeżeli nie można byłoby przyjąć, że pierwszy motor (primum movens) porusza się $z$ siebie, to trzeba by było uznać, że jest on poruszany bezpośrednio przez motor całkowicie nieruchomy. Zresztą sam Arystoteles pisał o alternatywie: albo należy przyjąć, że pierwszy motor jest całkowicie nieruchomy i oddzielony od innych bytów, albo - jeżeliby się stwierdziło, że porusza samego siebie - doszłoby się do wniosku, że istnieje inny pierwszy motor, który jest całkowicie nieruchomy i oddzielony od wszystkiego innego.

6. Wszechświat zakładany przez drugi wariant argumentacji kinetycznej Arystotelesa, podjętej w szerokim zakresie przez Tomasza z Akwinu, jest, oczywiście, tym samym wszechświatem, do którego odnosi się pierwszy wariant tej argumentacji. Jest to, jak wiemy, wszechświat, w którym ciała nieożywione są szeregami wprawiane kolejno w ruch od zewnątrz. Ponieważ nie jest to wszechświat rzeczywisty, dlatego już choćby z tego powodu musimy ujemnie ocenić drugą wersję argumentacji ex motu. Możemy jednak pytać się, czy przynajmniej dla implikowanej przez nią koncepcji wszechświata cel rozumowania został osiągnięty. To nam pozwoli ustalić stopień ścisłości logicznej wywodów.

Dla wartości drugiej argumentacji kinetycznej zasadnicze znaczenie posiada jej pierwsza część zmierzająca do wykazania, że istnieje jeden pierwszy motor, który nie jest poruszany z zewnątrz przez inny byt. Jeżeliby się okazało, że Stagiryta nie udowodnił istnienia jedyności tego rodzaj motoru, podjęcie się oceny jego dalszych prób dojścia do motoru całkowicie nieruchomego i oddzielonego od innych bytów, jakim miałby być Bóg, nie byloby czymś celowym na gruncie jego modelu wszechświata. W szukaniu dróg do efektywnego poznania istnienia Boga rozstalibyśmy się szybko z argumentacją przypisywaną Arystotelesowi przez Tomasza. Jaki jest więc faktyczny stan rzeczy?

Rozumowanie pierwszej części drugiej argumentacji kinetycznej Stagiryty przypomina od strony formalnej pewne rozumowanie z zakresu teorii zmiennej pozornej. Chodzi tu o wzór: $\sim[(\mathrm{x}) . \varphi \mathrm{x} \supset \psi \mathrm{x}] . \supset$. ( $\exists \mathrm{x}) . \varphi \mathrm{x} \supset$ $\supset \sim \psi \mathrm{x},{ }^{41}$ k'tórego poprawność łatwo dałoby się udowodnić, odwolując się do prawa negacji kwantyfikatora ogólnego dla funkcji zdaniowej „, $\mathrm{i}$ do jednego $\mathrm{z}$ praw negacji implikacji $\mathrm{z}$ dziedziny logiki zdań: $\sim(p \supset q) \cdot \supset \cdot p \supset \sim q$. Gdyby rozumowanie pierwszej części argumentacji

${ }^{41} \mathrm{~W}$ Principia mathematica A. N. Whiteheada i B. Russella nie ma tego wzoru, który wyraża adekwatnie stronę formalną uwzględnianego obecnie rozumowania Arystatelesa, wziętego w interpretacji Gilsona. 
Arystotelesa utożsamiało się pod względem formalnym z rozumowaniem wyrażonym w powyższym wzorze, nic nie można byłoby mu zarzucić, przynajmniej z punktu widzenia związków logicznych. Jednakowoż rozpatrywane przez nas rozumowanie nie utożsamia się bez reszty od strony formalnej $\mathrm{z}$ rozumowaniem zacytowanego wzoru teorii zmiennej pozornej. Poprzednik w obu formach rozumowania jest pojmowany identycznie. Jednakowoż różnica występuje w ujęciu następnika implikacji. We wzorze z zakresu teorii zmiennej pozornej kwantyfikator egzystencjalny należy tak rozumieć, że istnieje przynajmniej jedno indywiduum, dla którego z posiadaniem cechy ", " nie łączy się posiadanie cechy „, $\psi "$. Ale takich indywiduów może być więcej. Czy jest ich więcej, czy tylko jedno, tego nie możemy wiedzieć $\mathrm{z}$ samej negacji kwantyfikatora ogólnego. Tymczasem Arystoteles przyjął zupełnie dowolnie, że takie indywiduum jest tylko jedno. O tym, że taką faktycznie była myśl Stagiryty, przekonuje nas w tekście drugiej argumentacji kinetycznej ten szczegół, że o pierwszym motorze, nie poruszanym z zewnątrz przez inny byt, jest powiedziane, że albo jest on motorem całkowicie nieruchomym, a w konsekwencji Bogiem, albo jest motorem poruszającym siebie, którego aktywność domaga się przyjęcia istnienia innego nadrzędnego motoru całkowicie nieruchomego i oddzielonego od innych bytów. Arystoteles nie mógłby był przyjmować pierwszej możliwości, gdyby pierwszy motor, nie poruszany z zewnątrz przez inny byt, nie był - w jego przekonaniu - jedynym takim motorem. Ponieważ wniosek o istnieniu jednego tylko takiego motoru nie jest uzasadniony przez poprzednik implikacji, wobec tego, chociażby nawet Arystoteles był udowodnił, że zdanie: „każdy byt poruszający inne byty, jest sam poruszany" nie jest zdaniem prawdziwym ani per accidens, ani per se, czyli że jest zdaniem błędnym, to i tak nie udowodniłby, że istnieje jeden pierwszy motor nie poruszany z zewnątrz. Co najwyżej mógłby był Arystoteles powiedzieć, że istnieje przynajmniej jeden taki motor, ale nie jest wykluczone, że tych motorów jest więcej.

Po stwierdzeniu tego nie potrzebujemy badać, czy Stagiryta udowodnił dla swego modelu wszechświata, że teza wyrażająca myśl, iż każdy byt poruszający inne byty, jest sam poruszany, nie jest twierdzeniem prawdziwym ani per accidens, ani per se. Nie potrzebujemy również badać, jaka jest wartość drugiej części rozpatrywanej przez nas obecnie argumentacji kinetycznej Arystotelesa, w której tenże usiłuje wznieść się do pierwszego motoru całkowicie nieruchomego i oddzielonego od innych bytów, jakim ma być Bóg. Okazuje się bowiem, że znaleźliśmy się w obrębie rozumowania, które nie doprowadzi nas do celu nie tylko $\mathrm{z}$ racji swego powiązania $\mathrm{z}$ dawno zarzuconym przyrodniczym obrazem wszechświata. 
Sądzę, iż występując z tymi uwagami krytycznymi możemy ściśle wykazać, że zdanie: „każdy byt, który porusza inne byty, jest sam poruszany z zewnątrz" nie jest wyrazem żadnej konieczności ontycznej. Ale na bazie tego trafnego stwierdzenia nie będziemy konstruowali żadnej nowej kinetycznej argumentacji za istnieniem Boga już choćby $\mathrm{z}$ tego powodu, żeby nie znaleźć się $\mathrm{z}$ powrotem $\mathrm{w}$ ramach fikcyjnego modelu kosmosu.

\section{B. ARGUMENTACJA KINETYCZNA Z SUM. THEOL., I. QU. II, A. 3}

1. Ruch, którego genezę Tomasz usiłuje ostatecznie wyjaśnić w swej argumentacji kinetycznej z Sumy teologii, jest to $\mathrm{ruch}$ w $\mathrm{znacze}-$ niu ścisłym, stwierdzany w sposób pewny w ramach percepcjizmysłowej: „Certum est [...], et sensu constat, aliqua moveri in hoc mundo". Nie chodzi tu tylko o ruch lokalny, jak to prawdopodobnie miało miejsce $\mathrm{w}$ pierwszym wariancie argumentacji kinetycznej z Sum. c. Gent., ale również o fizyczny $\mathrm{ruch}$ jakośc i owy, gdyż egzemplifikacja Akwinaty nie tylko obejmuje poruszanie ręką laski, ale również ogrzewanie kawałka drewna przez ogień. Miożna by również wymienić nie wyszczególniony przez Tomasza fizyczny ruch ilościowy, ponieważ i on daje się zauważyć w obrębie percepcji zmysłowej. Gdy jednak Zdybicka pisze, że „w metafizycznym uzasadnieniu istnienia Boga Akwinata miał rozumieć ruch szeroko jako metafizycznie ujętą wszelką zmianę związaną $\mathrm{z}$ bytem skończonym, bo złożonym $\mathrm{z}$ różnorodnych elementów, które da się ująć w relacji: możność - akt" " ${ }^{42}$, trudno nie zauważyć, że odeszła od poglądów Tomasza, uważając za Krąpcem i Masim za ruch w znaczeniu ścisłym nie tylko ruch fizyczny, ale również jakąkolwiek zmianę.

Według interpretacji egzystencjalistycznej, podjętej przez Krąpca, Zdybicką i innych, ruch należy pojmować w argumentacji kinetycznej z Sumy teologii jako ,stawanie się [realnie] istniejącego bytu, krótko: [jako] stawanie się istnienia" [realnego] ${ }^{43}$. Zdaniem wymienionych autorów takie rozumienie ruchu narzuca się w oparciu o koncepcję bytu podzielaną przez Tomasza. Jak pisze Krąpiec, w tej koncepcji ,aktem bytu jest jego istnienie [realne], a możnością jest koniecznie przyporządkowana takiemu istnieniu substancja - istota" ${ }^{44}$. Ponieważ Akwinata pojmował ruch jako aktualizację możności, dlatego w jego systemie - jak

42 Analiza metodologiczna Tomaszowych form argumentacji za istnieniem Boga, a zwłaszcza argumentacji $z$ ruchu, 239, przyp. 14.

${ }_{43} \mathrm{Sa}$ to słowa $\mathrm{Krąpca} \mathrm{z}$ jego artykułu Filozofia $i$ Bóg, 40. Por. cyt. wyżej artykuł Zdybickiej, 238-239.

44 Art. cyt., 40. 
sądzi Krąpiec, a także Zdybicka - ruch przedstawia się jako stawanie się istnienia realnego.

Otóż, gdyby nawet było tak, jak utrzymuje Krąpiec, że „dla Tomasza być bytem znaczyło być [...] substancją [w sobie zdeterminowaną i ze sobą tożsamą dzięki formie], ale jako istniejącą [realnie]" ${ }^{45}$, to ruch w znaczeniu ścisłym trzeba byłoby pojmować w systemie Akwinaty jako stawanie się istnienia realnego wtedy tylko, gdyby w tym systemie termin ,akt" był terminem jednoznacznym, oznaczającym wyłącznie istnienie realne substancji. Tak jednak nie jest, gdyż dla Tomasza wymieniony termin był terminem a n a log i c z n y m, znajdującym zastosowanie nie tylko do istnienia realnego substancji, lecz również do ruchu, działania i formy rzeczy ${ }^{46}$. Wobec tego nie można powoływać się na koncepcję bytu, jaką - według Krąpca - podzielał Tomasz, gdy ruch, pojęty jako aktualizacja możności, przedstawia się jako stawanie się istnienia realnego. Wszak akt, o którym jest mowa $w$ tej koncepcji, nie wyczerpuje - zdaniem jej autora - wszystkich możliwości w zakresie aktu.

Możność wyprowadzenia egzystencjalistycznej interpretacji ruchu z Tomaszowej koncepcji bytu odpada jeszcze $\mathrm{z}$ tego powodu, że ta koncepcja, wzięta w swej autentycznej treści, nie zawiera tego ograniczenia się do istnienia realnego, jakie za Gilsonem podejmuje filozoficzna szkoła lubelska ${ }^{47}$. O tym, że tak jest, można przekonać się czytając Tomasza lekcję I do księgi IV Metafizyki Arystotelesa i De malo, a. 1, ad 20 te teksty, których Gilson nie uwzględnił przy referowaniu koncepcji bytu Akwinaty, a w których jest mowa, wyrażając się słowami cytowanej quaestio disputata, nie tylko o bycie rzeczy (ens rei), ale również o bycie rozumu (ens rationis), będącym in ratione [...] ut aliquid intellectum.

A dalej należy zauważyć, że nikt nie dowiódł podzielności istnienia realnego jako takiego. Nic nas obiektywnie nie upoważnia do mówienia o $1 / 4$, o połowie lub o $3 / 4$ istnienia realnego. Albo coś istnieje realnie w sposób niepodzielny, albo nie istnieje realnie. A jeżeli tak jest, akt

45 Tamże, 1.c. Por. jeszcze dzieła K r ą p c a: Teoria analogii bytu, 48-61; Struktura bytu, 8, 117, 144 (przyp. 95), 149, 235-237, 264-267, 275-279, 285-291; Metafizyka - Zarys teorii bytu, Lublin $1978^{2}, 39,112-114,292,373-374,404-405,452$, $491-492,502$.

46 Zob. Tomasza In Metaphysicam Aristotelis commentaria, lib. IX, lect. V. Por. jeszcze Krąp a Struktura bytu, $34-40$.

Gdy Akwinata pisał (1.c., n. 1828), że akt diversimode dicitur, to Krapiec tę wypowiedź sprowadza za A. B a u dinem (L'acte et puissance dans Aristote, „Revue Thomiste", 7 (1889)159) do formuły ściślejszej twierdząc, że pojęcie aktu jest pojęciem analogicznym.

Egzystencjalistyoznej interpretacji ruchu nie ma u Krąpca w wydaniu II jego Metafizyki (s. 260-264, 295-297). Ale nie było także w wydaniu I tego dzieła z r. 1966 (s. 249-254, 294-296), wyprzedzającym artykuł Filozofia i Bóg. Tłumaczy się ten fakt zapewne tym, że w Metafizyce analiza ruchu została przeprowadzona celem uzasadnienia teorii możności i aktu, a nie pod kątem następstw mających się narzucać z koncepcji bytu, jaką, według Krąpca, mial podzielać Tomasz.

47 Zob. Gils on: Le Thomisme, 43-68; L'être et l'essence, $78-120$. 
istnienia $w$ bycie realnym jest czymś n i e p odzi e l n y m, jak to przyznaje również Krapiec ${ }^{48}$, to jego twierdzenie o stawaniu się istnienia realnego nie ma s e n su, gdyż pojęcie stawania się czegoś zakłada podzielność, złożenie z części, które nie pojawią się wszystkie naraz, lecz stopniowo.

Ale mógłby mi ktoś zarzucić, że wysunięte przeze mnie zastrzeżenia odnoszą się do uproszczonej formuły, bo w pełniejszej formule jest mowa o stawaniu się istniejącego realnie bytu. Jeżeli jednak w tej pełniejszej formie chodzi o stawanie się bytu wziętego od strony jego istnienia realnego, a więc w jego istnie$\mathrm{n}$ i u rea lny m jako takim - a na takie rozumienie zdaje się wskazywać pominięcie w uproszczonej formule jednego tylko terminu: byt to przedstawione zastrzeżenia są, jak sądzę, w pełni słuszne.

Mówienie o stawaniu się istnienia realnego wywodzi się niewatpliwie $\mathrm{z}$ nieuświadomionej jego reifikacji ${ }^{49}$. Wszak wprowadzając stawanie w obręb istnienia realnego jako takiego, przypisuje się $\mathrm{mu}$ to, co może dotyczyć pewnego typu realnego bytu, mianowicie bytu materialnego. Razem $\mathrm{z}$ reifikacją dołącza się redukcjonizm ontyczny, gdyż przypadłość, jaką jest ruch, sprowadza się do istnienia realnego, ulegając przerostowi perspektywy egzystencjalnej ${ }^{50}$.

W dziełach Tomasza z Akwinu nie znalazłem wypowiedzi o stawaniu się istnienia realnego. Gdyby taka wypowiedź miała się tłumaczyć jego koncepcją bytu, jej brak byłby trudno zrozumiały u myśliciela tak analitycznego. Akwinata napisał tylko, że ruch jest drogą do substancji (via ad substantiam) ${ }^{51}$. Taka wypowiedź ma sens, choć należałoby ją wyrazić przy pomocy ścisłych terminów filozoficznych (jest bowiem wyrażona językiem potocznym), a ponadto należałoby zbadać, do jakich gatunków ruchu się odnosi.

2. Argumentacja kinetyczna, podana przez Tomasza w Sumie teologii, jest $\mathrm{w}$ zasadzie identyczna $\mathrm{z}$ pierwszym wariantem takiejże argumenta-

48 Struktura bytu, 10.

40 Swiadomej reifikacji istnienia realnego nie ma u Krapca. W Teorii analogii bytu (s. 55) przestrzega on przed zbyt reistycznym pojmowaniem rzeczywistej różnicy między istotą a istnieniem realnym $\mathrm{w}$ bytach samoistnych. ,Jeśli $\mathrm{w}$ bycie czym innym jest istnienie, a czym innym istota, to nie znaczy to wcale - pisze - by tak istnienie, jak $\mathrm{i}$ istota były jakimiś rzeczami uprzednio przed sobą istniejącymi, a dopiero potem lączyły się w uścisku rzeczywistego istnienia. Istnienie bowiem, jakkolwiek jest czymś innym niż istota - aliud - to jednak nie jest »rzeczą", lecz tylko elementem doskonalącym, urzeczywistniającym substancję, czyli istotę. Zreizowanie istnienia uniemożliwia pojęcie samego złożenia z istaty i istnienia." Por. jeszcze Krąpca: Struktura bytu, 279, 287; Metafizyka - Zarys teorii bytu, 406, $488-489$

${ }_{50}$ Nieuświadomiona reifikacja istnienia realnego i sprowadzenie do niego ruchu występują także w przeświadczeniu Krąpca, wyrażonym w dziele Struktura bytu (s. 61), że samo istnienie realne jest w ruchu.

${ }^{51}$ In Metaphysicam Aristotelis commentaria, lib. IV, lectio I, n. 539. 
cji z Sum. c. Gent. Cała różnica między jej ujęciem w obu tych dziełach polega na tym, że dowód obu tez kosmologicznych jest w Sum. theol. krótszy niż w Sumie filozoficznej ${ }^{52}$. I tak, z trzech dowodów przedstawionych $\mathrm{w}$ tym ostatnim dziele za pierwszą tezą z zakresu filozofii przyrody, wyrażającą arystotelesowską zasadę ruchu, powtórzył Tomasz w Sumie teologii tylko trzeci dowód, odwołujący się do pojęć możności i aktu ${ }^{53}$. Z trzech znów dowodów rozwijanych w Sum. c. Gent. na rzecz drugiej tezy kosmologicznej, głoszącej niemożliwość regresu w nieskończoność w obrębie serii bytów, z których każdy jest kolejno poruszany przez inny byt, uwzględnił Akwinata w Sumie teologii jedynie drugi dowód. Jest to dowód, w którym bierze się pod uwagę konsekwencje, jakie narzucają się dla uporządkowanej we wskazany sposób serii bytów poruszanych, gdyby nie było pierwotnego motoru. I jak w Sumie filozoficznej, tak również w Sum. theol. Tomasz nie dowodzi, że pierwszy motor, który nie jest poruszany przez inny byt, jest Bogiem. Jego zdaniem wszyscy rozumieją przez ten motor Boga ${ }^{54}$. Jedyna nowa myśl, jaką spotykamy w Sumie teologii, to uwaga, że argumentacja za istnieniem Boga z ruchu ma pierwszeństwo przed pozostałymi formami argumentacji i jest od nich bardziej oczywista ${ }^{55}$.

3. Ponieważ argumentacja kinetyczna z Sumy teologii stanowi część wywodów pierwszej argumentacji ex motu z Sum. c. Gent., dlatego w zasadzie nie trzeba byłoby dodawać żadnych nowych uwag krytycznych do tych, jakie już zostały podane w przedmiocie wskazanego rozumowania Akwinaty $\mathrm{z}$ jego młodzieńczego dzieła. Trudno jednak nie ustosunkować się do wpływowej interpretacji, jaką współcześnie wysunął Krąpiec, a za nim Zdybicka ${ }^{56}$, w odniesieniu do argumentacji kinetycznej z Sum. theol.

Według Krąpca ta argumentacja jest ,uwikłana w obraz świata i stan nauk właściwy dla XIII wieku”. Ale to „uwikłanie” wyraża się tylko wprowadzeniem egzemplifikacji $\mathrm{z}$ ówczesnego przyrodniczego obrazu świata. Stąd też, zdaniem Krąpca, tego rodzaju „uwikłanie” „nie jest

${ }^{52}$ Pominięcie w Sum. theol. pewnych dowodów z Sumy filozoficznej, wysuniętych na rzecz abu tez $\mathrm{z}$ zakresu filozofii przyrody, niekoniecznie musi tłumaczyć się tym, że Tomasz $z$ czasem stracił do nich przekonanie. Akwinata mógł dalej uważać te dowody za całkowicie poprawne, a pominął je tylko dla uproszczenia argumentacji, kierując się celem, o którym pisze w prologu Sumy teologii.

${ }^{53}$ Ten dowód rozwinął Tomasz w swym głównym dziele nieco szerzej niż w Cum. c. Gent.

54 "Ergo necesse est devenire ad aliquod primum movens, quod a nullo movetur: et hoc omnes intelligunt Deu m". Podkreślenie moje.

55 "Prima autem et manifestior via est, quae sumitur ex parte motus." - Tomasz zapewne dlatego uznał ostatecznie argumentację kinetyczną za pierwszą, gdyż ona wychodzi od najpowszechniejszej i najbardziej uderzającej właściwości bytów materialnych.

56 Art. cyt., $237-242$. 
istotne dla przeprowadzonego toku rozumowania i jego siła dowodowa nie osłabła" ${ }^{57}$.

Argumentacja Tomasza jest więc - jak sądzi Krąpiec - argumentacją czysto filozoficzną. Ten jej charakter epistemologiczny ma tłumaczyć się pozytywnie tym, że ruch został w niej pojęty metafizycznie w podany wyżej sposób ${ }^{58}$.

Rozumowanie Tomasza wyraża, według Krąpca, myśl, ,że byt nie da się uzasadnić niebytem; że wszystko to, co z »niebytu własnego« przechodzi do bytu, ma swe uzasadnienie $\mathrm{w}$ bycie, ostatecznie $\mathrm{w}$ bycie takim, który jest bytem na mocy własnej, jest bytem $\gg \mathrm{z}$ definicji ${ }^{59}$, bytem, który jest ,tylko istnieniem” [realnym] ${ }^{60}$, który jest czystym istnieniem realnym ${ }^{61}$.

4. W odniesieniu do tej egzystencjalistycznej interpretacji rozumowania Tomasza z Sumy teologii narzuca się najpierw pytanie, czy rzeczywiście jest tak, jak utrzymuje Krąpiec, że to rozumowanie jest w s obi e niezależne od trzynastowiecznego obrazu przyrodniczego świata, gdyż z tego obrazu czerpie tylko swą egzemplifikację, a więc coś o charakterze przygodnym, co mogłoby ulec zmianie na inną egzemplifikację, na przykład na egzemplifikację współczesną?

$\mathrm{Na}$ to pytanie trzeba odpowiedzieć n e gaty w ni e, gdyż Tomasz nie byłby tak rozumował w Sumie teologii, jak to zrobił, gdyby nie był zakładał - zgodnie ze współczesnym mu przyrodniczym obrazem świata - że ciała nieożywione mogą wprawiać w ruch inne tego rodzaju ciała o tyle tylko, o ile podlegają aktualnemu poruszaniu z zewnątrz, a więc o ile są samymi instrumentalnymi przyczynami ruchu. To założenie tłumaczy nam, dlaczego tak samo jak w Sum. c. Gent. spożytkował Akwinata w swym głównym dziele arystotelesowską zasadę ruchu jako zasadę aktualnego poruszania $\mathrm{z}$ zewnątrz przez odrębne indywiduum i dlaczego utrzymywał, że w serii bytów poruszających inne i poruszanych nie można posuwać się $\mathrm{w}$ nieskończoność. Rozumowanie Tomasza nie było więc czystym rozumowaniem filozoficznym, wziętym w sensie treściowej niezależności od ówczesnych wyobrażeń przyrodniczych. Wskutek też tego nie można twierdzić, że ,jego siła dowodowa obecnie nie osłabła".

Ale Krąpiec bierze pod uwagę nie autentyczną argumentację Akwinaty, lecz jej własną interpretację, według której ruch, mający być stawaniem się istnienia realnego, znajduje swe ostateczne wytłumaczenie

\footnotetext{
57 Art. cyt., 39.

58 Tamże, $40-41$.

59 Tamże, 41.

60 Tamże, l.c.

61 Tamże, 40.
} 
w bycie, jaki stanowi czyste istnienie realne. Rozumowanie, które - według profesora lubelskiego - znajduje się w Sumie teologii, jest czystym rozumowaniem filozoficznym, gdyż w sobie jest ono niezależne od jakiegoś określonego przyrodniczego obrazu świata. Nie jest to jednak żadna argumentacja kinetyczna. Jej charakter semantyczny nie został dostatecznie wyprecyzowany, ale jest to coś zbliżonego do argumentacji z przyczynowości sprawczej, a ostatecznie z przygodności rzeczy. Słabą stroną tej argumentacji, dalekiej od autentycznej myśli Akwinaty, jest głównie to, że jest próbą rozwiązania pseudoproblemu, wyrosłego na gruncie nieadekwatnej, egzystencjalistycznej interpretacji ruchu.

5. Występując z tymi zarzutami nie przeczę jednak, że argumentację kinetyczną Tomasza z Sumy teologii (a także z innych jego dzieł) można w drodze abstrakcji tak u o góln ić, żeby ją oderwać od jakiegokolwiek przyrodniczego obrazu świata, zachowując tylko, jak pisze Zdybicka ${ }^{62}$, zasadniczą jej myśl. Dokonując tego uogólnienia będziemy mówili nie o ruchu fizycznym, lecz o zmianie, o jakiejkolwiek zmianie - nie o tym, że coś porusza inny byt, lecz że go wyprowadza z możności do aktu. W ten sposób znikną z argumentacji kinetycznej rażące nas dziś ,,motory”. Nie wprowadzimy także pojęcia pierwszego motoru całkowicie nieruchomego. Zamiast niego posłużmy się pojęciem czystego aktu.

Wtedy za Zdybicką argumentacja Tomasza przedstawi się nam w sposób skrótowy następująco: „Punktem wyjścia jest istnienie bytów zmieniających się, to znaczy takich, w których istnieją elementy potencjalne i aktualne. Żaden żtegs rodzaju bytów nie może być przyczyną własnego stawania się, gdy sobie to, czego nie posiada. Dowód kończy się afirmacją istnienia takiego bytu, który nie posiada potencjalności, sam tłumaczy swoje istnienie jest czystym, absolutnym aktem" ${ }^{63}$.

Ten zarys argumentacji łatwo byłoby rozwinąć, uściślić. Należałoby tylko wyeliminowac jej egzystencjalistyczną interpretację, którą Zdybicka przyjmuje, jak wynika z całokształtu jej wypowiedzi o ,pierwszej drodze" Tomasza. Trzeba by także unikać twierdzenia, że ta wydzielona dzięki abstrakcji najbardziej istotna treść argumentacji kinetycznej Akwinaty stanowi jedyną możliwą współcześnie formę jej wyrażenia. Jak zobaczymy przy całościowym omawianiu krytycznym Tomaszowych wariantów argumentacji kinetycznej, można tę argumentację tak przekształcić, że będzie harmonizowała ze współczesnym obrazem przyrodniczym świata. A wtedy będziemy bliżsi stylu filozofowania Tomasza, który swe

${ }^{62}$ Art. cyt., 242.

63 Tamże, 1.c. 
próby argumentacji ex motu formułował nie w oparciu o ogólnikowe doświadczenie zmienności świata, lecz w ramach przyrodniczych wyobrażeń swojej epoki.

\section{ARGUMENTACJA KINETYCZNA Z COMPENDIUM THEOLOGIAE PRIMA PARS, C. III - XXXIV ${ }^{64}$}

1. W roz. III pierwszej części niedokończonego dziełka Compendium theologiae Tomasz $\mathrm{z}$ Akwinu nie uwzględnił przynajmniej wyraźnie $\mathrm{u}$ podstaw swej argumentacji kinetycznej innego ruchu niż $\mathrm{ruch}$ lo$\mathrm{k}$ a ln y. Będzie to widoczne ze streszczenia jego argumentacji.

Argumentacja ta nie różni się w zasadzie od pierwszego wariantu argumentacji kinetycznej z Sum. c. Gent., a także od takiejże argumentacji z Sumy teologii. Pewną nowość stanowi tylko próba udowodnienia pierwszej tezy kosmologicznej — arystotelesowskiej zasady ruchu - na drodze indukcji, i to, jak się zdaje, indukcji zupe łnej, z poszczególnych danych empirycznych. Tomasz opowiedział się mianowicie za zdaniem, że doświadczenie nas uczy (,Videmus ..."), iż wszystko, cokolwiek się porusza, jest poruszane przez coś innego. Dla przykładu wymienił „,pierwiastki” w rozumieniu arystotelesowskim, które, jego zdaniem, są poruszane przez ciała niebieskie ${ }^{65}$. Dowód drugiej tezy z zakresu filozofii przyrody, wyrażającej niemożliwość posuwania się w nieskończoność w serii bytów poruszających inne i poruszanych, jest powtórzeniem trzeciego dowodu z Sum. c. Gent. O pierwszym motorze napisał Tomasz, że zajmuje pierwsze miejsce w hierarchii bytów (quod sit omnibus supremum) i dlatego nazywamy go Bogiem.

2. W Compendium theologiae nie zadowolił się Akwinata takim skrótowo uzasadnionym utożsamianiem pierwszego motoru z Bogiem, lecz starał się swoje końcowe twierdzenie ściśle dowieść wykazując, że pierwszy motor jest całkowicie nieruchomy (roz. IV, że jest wieczny (roz. V), że jego istnienie jest konieczne per se (roz. VI), że istnieje zawsze (roz. VII), ${ }^{66}$ że nie ma w nim żadnego następstwa (roz. VIII), że jest bytem pojedynczym (roz. IX), że jest swoją istotą (roz. X), że jego istota nie różni się od jeg istnienia (roz. XI), że jest jeden (roz. XV) ${ }^{67}$, że nie jest ciałem (roz. XVI), że nie jest formą ciała lub siłą zawartą w ciele (roz. XVII), że jest nieskończony pod względem swej istoty (roz. XVIII), że

64 Opieram się na wydaniu Mandonneta (S. Thomae Aquinatis Opuscula omnia, t. II).

65 „Videmus enim omnia quae moventur, ab aliis moveri, inferiora quidem per superiora, sicut elementa per corpora coelestia [...]". Cap. III.

${ }_{66}$ Nie poruszam w tej chwili kwestii, czy w rozdziale VII nie chodzi o tę samą teze, o jakiej jest mowa w rozdziale $\mathrm{V}$.

${ }_{67}$ Póżniej wyjaśnię, dlaczego pomijam treść rozdziałów XII-XIV. 
posiada moc nieskończoną (roz. XIX), że jego nieskończoność nie mieści w sobie żadnej niedoskonałości (roz. XX), że posiada w stopniu najwyższym wszelką doskonałość, jaka występuje w rzeczach otaczającego nas świata (roz. XXI), że wszystkie jego doskonałości są rzeczowo czymś jednym (roz. XXII), że nie ma w nim żadnej przypadłości (roz. XXIII), że jest obdarzony umysłem (roz. XXVII) ${ }^{68}$, że jego poznanie umysłowe nie przedstawia się nigdy jako możność lub jako stała sprawność, lecz jest wyłącznie aktem (roz. XXIX), że nie poznaje przez inną podobiznę, jak przez swoją istotę (roz. XXX), że jest swoim poznaniem umysłowym (roz. XXXI), że występuje w nim chcenie rozumne (roz. XXXII), że jego wola nie różni się rzeczowo od jego umysłu (roz. XXXIII) i że jego wola jest samym jego chceniem rozumnym (roz. XXXIV).

Rozpatrzmy teraz szczegółowo tę dedukcję Tomasza.

Zanim zacznę streszczać jego rozumowanie chciałbym zaznaczyć, że stale, aż do uwzględnienia całości dedukcji, będę pomijał utożsamianie się pierwszego motoru z Bogiem, chociaż Tomasz, począwszy od rozdziału V, niemal ustawicznie je uwzględnia. Będę pomijał to utożsamianie dlatego, bo wydaje się, że ono tylko zaciemnia myśl Tomasza odnośnie do właściwości, jakie mają przysługiwać pierwszemu motorowi nieruchomemu. Takie przedstawienie nie będzie zniekształceniem myśli Akwinaty, bo jeżeli on mówi wyraźnie, że pierwszy motor jest całkowicie nieruchomy, to tym samym utrzymuje, że ten motor jest wieczny, chociaż $\mathrm{w}$ rozdziale $\mathrm{V}$ pisze, że Bóg jest wieczny. To samo trzeba powiedzieć w odniesieniu do innych atrybutów, przypisywanych explicite Bogu. Dla ścisłości muszę jednak zaznaczyć, że poniższa dedukcja w większości przypadków będzie się mieściła tylko implicite w tekście Compendium theologiae. Niemniej jednak będzie to, w gruncie rzeczy, dedukcja samego Tomasza.

3. Swą dedukcję Tomasz rozpoczął w rozdziale IV od próby wykazania, że pierwszy motor jest całkowicie nieruchom y (omnino immobilis). Za tą właściwością pierwszego motoru przytoczył d w a wywody.

D ow ód pierwszy: Jeżeliby pierwszy motor był poruszany, byłby poruszany albo przez samego siebie, albo przez inny byt. Tę ostatnią możliwość trzeba wykluczyć, bo gdyby pierwszy motor był poruszany przez inny byt, istniałby przed nim jakiś inny motor, a to nie dałoby się pogodzić z istotą pierwszego motoru. Jeżeli znów idzie o pierwszą możliwość, to można by ją pojąć w dwojaki sposób. Albo w ten sposób, że pierwszy motor jest pod tym samym względem czynnikiem poruszają-

68 Pominięcie rozdziałów XXIV-XXVII zostanie uzasadnione w trakcie dalszej analizy tekstu. 
cym i rzeczą poruszaną, albo w ten sposób, że pod jednym względem jest on czynnikiem poruszającym, a pod innym względem jest rzeczą poruszaną. Pierwszy przypadek jest jednakże niemożliwy do przyjęcia. Jeżeli bowiem wszystko to, co jest poruszane, o ile jest poruszane, jest w możności, a to, co porusza, jest w akcie - to w takim razie, gdyby pierwszy motor był pod tym samym względem czynnikiem poruszającym i rzeczą poruszaną, musiałby być pod tym samym względem w możności i akcie, a to jest niemożliwością. Ale i drugi przypadek jest nie do przyjęcia. Jeżeliby bowiem coś innego było czynnikiem poruszającym, a co innego rzeczą poruszaną, to byt, w którym by to miało miejsce, nie byłby pierwszym motorem, o ile jest pewną całością (secundum se), ale byłby pierwszym motorem jedynie z racji tej części, która jest źródłem ruchu całości. Ponieważ znów to, co jest per se, jest wcześniejsze od tego, co nie jest per se, wobec tego trzeba było przyjąć, że przed motorem, poruszającym się dzięki jednej swojej części, istnieje motor, który ma źródło ruchu w sobie, o ile jest całością. Tego znów nie można by było przyjąć, bo założyliśmy, że nasz motor jest pierwszym motorem. Wobec tego trzeba się zgodzić, że nie mogłoby być pierwszym motorem to, co poruszałoby się $\mathrm{z}$ racji jednej swojej części ${ }^{69}$. W ten sposób dochodzimy do wniosku, że pierwszy motor jest całkowicie nieruchomy, bo ani nie jest poruszany przez inny byt, ani nie jest poruszany przez siebie samego.

D o w ód drugi: To samo, co zostało ostatnio powiedziane, wynika również ze stosunków zachodzących między rzeczami poruszanymi i poruszającymi. Każdy bowiem ruch zdaje się pochodzić od czegoś nieruchomego, to znaczy od tego, co nie jest poruszane według tego samego gatunku ruchu. Uczy nas o tym doświadczenie, które wskazuje na to, że zmiany dokonujące się na Ziemi, jak psucie się istniejących bytów, powstawanie nowych i zanikanie dawnych, sprowadzają się, jako do swego pierwszego motoru, do ciała niebieskiego, które nie jest poruszane według tego samego gatunku ruchu, będąc czymś niezrodzonym, niezniszczalnym i nie podlegającym psuciu. Wobec tego to, co jest pierwszą zasadą wszelkiego ruchu, musi być całkowicie nieruchome.

4. Z tego, że pierwszy motor jest całkowicie nieruchomy, wyprowadza Tomasz w rozdziale V wniosek, że jest bytem wi e c z n y m, tzn. bytem nie mającym początku i końca swego istnienia ${ }^{70}$. Jeżeli bowiem zaczyna istnieć lub traci istnienie to tylko, co podlega ruchowi lub zmia-

69 Ostatnie trzy zdania wyrażają pełny sens nasitępującego tekstu Tomasiza, zredagorwanego bandzo skrótorwo: „Quod autem est per se, prius est eo quod non est per se. Non potest igitur primum movens esse, si ratione suae partis hoc ei conveniat".

$70 \mathrm{Za}$ takim rozumieniem terminu: wieczny (aeternus) przemawiają dwa następne zdania: „Omne enim quod incipit esse, vel desinit, per matum, vel per mutationem hoc patiitur. Ostensum est autem, quod Deus est omnino immobilis, est ergo aeternus". 
nie, to $\mathrm{w}$ takim razie — sądzi Tomasz — pierwszy motor, jako całkowicie nieruchomy, jest wieczny w podanym znaczeniu.

$\mathrm{Z}$ absolutnej nieruchomości pierwszego motoru wyprowadza jeszcze Tomasz w rozdziale VI wniosek, że is tnienie tego motoru jest przez siebie (per se) czymś koniecznym. Najpierw jednak dowodzi tezy bardziej minimalistycznej, że istnienie pierws zego motoru odznacza się koniecznością. Na rzecz tej tezy przytacza d w a dowody.

Dow ód pierwszy: To, co może istnieć i nie istnieć, jest zmienne (mutabile). Tymczasem pierwszy motor jest, jak to zostało udowodnione, całkowicie nieruchomy. Wobec tego nie może on istnieć i nie istnieć. Lecz wszystko to, co istnieje i nie może nie istnieć, istnieje z konieczności, gdyż istnieć z konieczności i nie móc nie istnieć znaczy to samo. W takim razie trzeba powiedzieć, że pierwszy motor istnieje z konieczności.

Dow ód drugi: To, co może istnieć i nie istnieć, domaga się innego bytu, który by mu dał istnienie, gdyż z siebie jest indyferentne tak na istnienie, jak i na nieistnienie. Lecz to, co daje istnienie drugiemu, wyprzedza go $\mathrm{w}$ istnieniu. $\mathrm{W}$ takim razie to, co może istnieć $\mathrm{i}$ nie istnieć, jest poprzedzone $\mathrm{w}$ istnieniu przez coś innego. Ponieważ pierwszego motoru nic nie może wyprzedzać w istnieniu, wobec tego pierwszemu motorowi nie może przysługiwać możność istnienia i nieistnienia, lecz pierwszy motor z konieczności istnieje.

Zasadniczą tezę rozdziału VI, że istnienie pierwszego motoru jest czymś koniecznym przez siebie (per se, per seipsum), udowadnia Tomasz przy pomocy następującej argumentacji: Są pewne byty konieczne, które mają przyczynę swojej konieczności. Ta przyczyna wyprzedza je w istnieniu. Lecz pierwszy motor jest pierwszy z wszystkich bytów. Wobec tego pierwszy motor nie posiada przyczyny swojej konieczności, a w konsekwencji jego istnienie jest czymś koniecznym przez siebie.

5. W rozdziale VII Tomasz dochodzi do wniosku, że pierwszy motor istnieje zawsze (semper est). Nie jest to jakiś nowy wniosek w jego dotychczasowej dedukcji, gdyż ten sam wniosek miał na uwadze, gdy w rozdziale $\mathrm{V}$ usiłował dowieść, że pierwszy motor jest bytem wiecznym. Nawrót do wniosku wcześniejszego rozdziału tłumaczy się tym, że obecnie Tomasz uzasadnia go częściowo w nowy sposób, bo w oparciu o obie tezy rozdziału VI. Tego uzasadnienia dokonuje na c ztery sposoby.

S posó b pier w s z y: To, co istnieje z konieczności, zawsze istnieje, gdyż w odniesieniu do tego, co nie może nie istnieć, trzeba powiedzieć, że jest rzeczą niemożliwą, żeby nie istniało, a w konsekwencji należy 
twierdzić, że zawsze istnieje. Lecz istnienie pierwszego motoru jest czymś koniecznym. Wobec tego ten motor istnieje zawsze.

Sposób drugi: Wszystko zaczyna istnieć lub traci istnienie wyłącznie przez ruch lub zmianę. Ponieważ pierwszy motor jest całkowicie nieruchomy, wobec tego jest rzeczą niemożliwą, żeby zaczął istnieć w czasie lub w czasie utracił swoje istnienie. Dlatego też pierwszy motor istnieje zawsze.

S posób trzeci: Wszystko, co nie zawsze było, jeśli zaczyna istnieć, domaga się innego bytu, który byłby przyczyną jego istnienia, gdyż nic nie wyprowadza samo siebie z możności do aktu lub nieistnienia do istnienia. Otóż jeżeli pierwszy motor nie posiada żadnej przyczyny swego istnienia, gdyż jest pierwszym bytem (przyczyna jest bowiem pierwsza od skutku), to wymieniony motor istnieje zawsze.

Sposób czwarty: To, co nie przysługuje czemuś z racji przyczyny zewnętrznej, przysługuje mu przez niego samego. Istnienie nie przysługuje pierwszemu motorowi przez jakąś przyczynę zewnętrzną, gdyż ta przyczyna byłaby od niego wcześniejsza. Wobec tego pierwszy motor posiada istnienie przez siebie samego. Lecz to, co istnieje przez siebie (per se), istnieje zawsze i z konieczności. Wobec tego pierwszy motor istnieje zawsze.

6. W rozdziale VIII dowodzi Tomasz, że w pierwszym motorze $\mathrm{n}$ i e ma ża dnego następstwa czasowego, gdyż on c a łe swoje istnienie posiada naraz. Oto rozumowanie Akwinaty:

Następstwo czasowe występuje tylko w tych bytach, które są w jakiś sposób poddane ruchowi, gdyż „wcześniej” i „później”, pojawiające się w ruchu, warunkuje następstwo czasowe. Pierwszy motor nie jest w żaden sposób poddany ruchowi i dlatego nie ma w nim jakiegoś następstwa czasowego, lecz jego istnienie dopełnia się całe naraz.

Do tego samego wniosku prowadzi następujące rozumowanie: Jeżeliby jakiś byt nie posiadał całego swojego istnienia naraz, to mógłby coś utracić i coś zyskkać. Traci się jednak to, co przemija, a zyskać można to, czego się w przyszłości spodziewamy. Lecz pierwszy motor nic nie traci. ani niczego nowego nie zyskuje, gdyż jest nieruchomy. Wobec tego całe swoje istnienie posiada naraz.

Z wywodów rozdziału VII i VIII Tomasz wyprowadza dodatkowo wniosek, że pierwszy motor jest wi e c z n y w sensie właści w y m (proprie est aeternus). To bowiem jest w ten sposób wieczne, co istnieje zawsze i co istnieje całe naraz stosownie do definicji Boecjusza, że wiecznością jest posiadanie całe naraz i doskonałe życia bez początku i końca (interminabilis vitae tota simul et perfecta possessio). Wynikiem syntetyzującym treść rozdziałów VII i VIII Akwinata pogłębia sens tezy wysunię- 
tej już w rozdziale $\mathrm{V}$, że pierwszy motor jest wieczny, o ile nie ma początku i końca swego istnienia.

7. W rozdziale IX wykazuje Tomasz, że pierwszy motor jest bytem całkowicie pojedynczym, niezłożonym.

W każdym bycie złożonym - pisze - muszą występować dwie części, które mają się tak do siebie, jak możność do aktu. Lecz w pierwszym motorze, który jest całkowicie nieruchomy, nie może występować możność z aktem, gdyż to, co jest w możności, jest ruchome. Trzeba więc przyjąć, że jest rzeczą niemożliwą, by pierwszy motor był bytem złożonym.

Jest to także niemożliwe - twierdzi dalej Tomasz - z tego powodu, że w przypadku każdego bytu złożonego musi istnieć coś takiego, co by ten byt wyprzedzało, gdyż czynniki składowe są z natury wcześniejsze od całości. To więc, co wśród wszystkich bytów jest pierwszym bytem, nie może być czymś złożonym. Wniosek ten znajduje poparcie w doświadczeniu. Wskazuje ono na to, że w porządku rzeczy byty pojedyncze wyprzedzają byty złożone, jak to się dzieje z pierwiastkami [w rozumieniu arystotelesowskim], które z natury są wcześniejsze od ciał złożonych. Doświadczenie wskazuje również na to, że ogień, który jest pierwszym spośród pierwiastków, jest najbardziej pojedynczy. Doświadczenie mówi również o tym, że ciało niebieskie, które jest wcześniejsze od wszystkich pierwiastków, posiada większą pojedynczość, gdyż jest wolne od wszelkiej niezgodności cech. Wszystkie te dane doświadczenia przemawiają za tym, że pierwszy motor, będący pierwszym spośród bytów, musi być w swej naturze całkowicie pojedynczy, prosty.

8. W rozdziale $\mathrm{X}$ udowadnia Tomasz tezę, że pierwszy motor jest swoją is totą (est sua essentia).

Przez twierdzenie, że pierwszy motor jest swoją istotą, chce Tomasz powiedzieć, że w pierwszym motorze nie ma nic takiego, co by $-\mathrm{z}$ racji swego charakteru przygodnego - nie należało do jego istoty. To twierdzenie jest dla Tomasza wnioskiem $\mathrm{z}$ tezy poprzedniego rozdziału, że pierwszy motor jest całkowicie pojedynczy.

Do twierdzenia rozdziału $\mathrm{X}$ dochodzi Tomasz jeszcze $\mathrm{w}$ inny sposób, biorąc za punkt wyjścia tezę, że w pierwszym motorze nie ma złożenia z możności i aktu, gdyż jest on czystym aktem: W bytach, z którymi ich istota nie utożsamia się całkowicie, występuje coś na sposób możności i coś na sposób aktu, ponieważ istota danego bytu przedstawia się formalnie jako jego akt, a ten byt jako możność ${ }^{71}$. Lecz w pierwszym motorze nie ma złożenia $\mathrm{z}$ możności i aktu, gdyż jest on czystym aktem. $\mathrm{Z}$ tego też powodu pierwszy motor jest swoją istotą.

71 Tomasz pisze tylko tyle: ,nam essentia formaliter se habet ad rem cuius est essentia, sicut humanitas ad "hominem". 
9. W rozdziale XI przechodzi Tomasz do twierdzenia, że is tota pierwszego motoru nie jest czymśróżym od jego is $\mathrm{t} n$ i e $\mathrm{n}$ i a.

Tego twierdzenia dowodzi najpierw w oparciu o tezę, która głosi, że pierwszy motor jest byłem całkowicie pojedynczym: W każdym bycie, w którym istota i istnienie różnią się między sobą realnie, musi być czym innym to, przez co ten byt jest, i czym innym to, przez co ten byt jest czymś, gdyż ze względu na istnienie mówimy o czymś, że jest, a ze względu na istotę mówimy, czym jest. Lecz w pierwszym motorze to, że on jest, i to, że ma określoną istotę, nie różni się między sobą realnie, gdyż pierwszy motor jest bytem pojedynczym. Wobec tego jego istota nie różni się realnie od jego istnienia.

Tezę rozdziału XI udowadnia Tomasz jeszcze w inny sposób, biorąc za punkt wyjścia założenie, że pierwszy motor jest aktem czystym, bez jakiejś domieszki możności. To rozumowanie przedstawia się następująco: Z tego, że pierwszy motor jest aktem czystym, wolnym od wszelkiej możności, wynika, że jego istota musi być aktem ostatecznym (ultimus actus). Aktem bowiem ostatecznym jest to, do czego dąży każdy ruch, i czego wszystko pożąda. Akt ostateczny jest znów swoim istnieniem. Stąd też istota pierwszego motoru, która jest aktem czystym i ostatecznym, jest swoim istnieniem.

10. W rozdziale XII dowodzi Tomasz, że pierwszy motor nie znajduje się w jakimś rodzaju jako jego gatunek (non est in aliquo genere sicut species). W rozdziale XIII wykazuje, że pierwszy motor nie jest rodzajem czegoś (genus alicuius). Wreszcie w rozdziale XIV udowadnia, że pierwszy motor nie jest jakimśs gatunkiem, orzekanym o wielu indywiduach (non est aliqua species praedicata de multis individuis). Wywody tych trzech rozdziałów pomijam, gdyż obecnie, kierując się względem na ekonomię myślenia, nie poruszamy zbędnych problemów, o jakich jest w nich mowa. Przechodzę od razu do rozdziału XV, w którym Tomasz uzasadnia tezę, że pierwszy motor jest tylko je d e n.

Z trzech dowodów, które mają wykazać jedność pierwszego motoru, pomijam dowód pierwszy, gdyż opiera się on na wnioskach opuszczonych przez nas rozdziałów.

Dow ód drugi przedstawia się następująco: To, przez co istota wspólna (essentia communis) znajduje ujednostkowienie, nie może przysługiwać wielu jednostkom. Stąd też, chociaż może być wielu ludzi, to jednak ten określony człowiek może być tylko jeden. Jeżeli więc dana istota jest ujednostkowiona sama przez siebie, a nie przez coś innego, 
to nie może przysługiwać wielu jednostkom. Lecz istota pierwszego motoru jest ujednostkowiona przez samą siebie, gdyż w tym motorze nie jest czym innym istota $\mathrm{i}$ to, co jest, skoro pierwszy motor jest swoją istota. Wobec tego pierwszy motor jest tylko jeden.

Do tego samego wniosku dochodzi Tomasz na drodze innego rozumowania, stanowiącego trzeci dow ód: W dwojaki sposób dana forma może być uwielokrotniona (potest multiplicari). Jeden zasadza się na dodaniu do niej określonych różnic (per differentias). Za przykład może służyć taka forma ogólna jak kolor, który rozpada się na różne gatunki kolorów ${ }^{72}$. Drugi sposób uwielokrotnienia formy dokonuje się za pośrednictwem podmiotu, który ją przyjmuje w siebie. Taka forma, jaką jest kolor biały, może być uwielokrotniona na skutek przyjęcia jej przez wiele podmiotów. Wszelka zaś forma, która nie może być uwielokrotniona przez dodanie do niej określonych różnic, jeżeli nie jest formą istniejącą w jakimś podmiocie, nie może być uwielokrotniona. I tak, gdyby na przykład białość istniała bez podmiotu, byłaby tylko jedna. Lecz istota pierwszego motoru jest jego istnieniem, które nie przyjmuje w siebie żadnego zróżnicowania. Otóż, ponieważ istnienie pierwszego motoru jest jakby formą istniejącą przez siebie (quasi forma per se subsistens) z tej racji, że ten motor jest swoim istnieniem, dlatego może on być tylko jeden.

11. W rozdziale XVI Tomasz wyprowadza wniosek, że pier ws z y motor nie może być ciałem.

Wniosek ten wynika najpierw - zdaniem Tomasza - z tezy, która głosi, że pierwszy motor jest bytem całkowicie pojedynczym. Jeżeli bowiem w każdym ciele występuje jakieś złożenie, gdyż każde ciało posiada części, to w takim razie byt całkowicie pojedynczy nie może być ciałem. Ponieważ pierwszy motor posiada naturę absolutnie prostą, wobec tego nie można w nim dopatrywać się ciała.

Do takiego samego wniosku możemy dojść — według Tomasza gdy weźmiemy za punkt wyjścia tezę o bezwzględnej nieruchomości pierwszego motoru. Żadne bowiem ciało nie porusza innych ciał, jak tylko w przypadku, gdy samo jest poruszane. Jeżeli więc pierwszy motor ${ }^{78}$ jest całkowicie nieruchomy, to nie może być ciałem.

12. W rozdziale XVII Tomasz stara się wykazać, że pier wszy

$72 \mathrm{~W}$ wydaniu Mandonneta mamy: ,sicut forma generalis, ut c a lor in diversas species coloris”. (Podkreślenie moje). To „calor” jest niewątpliwie błędem. Powinno być ,color". Trudno przypuścić, żeby błąd mieścił się w ostatnim wyrazie, żeby miało być ,caloris”, a nie „coloris”, bo wteidy wzmianka o różnych gatunkach nie miałaby sensu.

${ }^{73} \mathrm{~W}$ tym rozdziale, jak i $\mathrm{w}$ dwu następnych rozdziałach, Tomasz mówi wyraźnie o pierwszym motorze (primum movens). 
motor nie może być formą ciała lub siłą zawartą w ciele. Argumentuje najpierw tak:

Ponieważ każde ciało jest podległe ruchowi, wobec tego, gdy ciało zostanie wprawione w ruch, będzie poruszane przynajmniej per accidens to wszystko, co się w nim znajduje. Lecz pierwszy motor nie może być poruszany nawet per accidens, gdyż musi być całkowicie nieruchomy, jak to zostało udowodnione. Wobec tego jest rzeczą niemożliwą, żeby pierwszy motor był formą ciała lub siłą zawartą w ciele.

Do tego samego wniosku prowadzi jeszcze - zdaniem Tomasza następujące rozumowanie: Każdy motor do tego, by mógł poruszać inny byt, musi posiadać nad nim panowanie (dominium). Im więcej siła poruszająca przekracza siłę bytu poruszanego, tym jego ruch jest szybszy. To więc, co pośród wszystkich czynników poruszających jest pierwszym motorem, musi posiadać maksimum panowania nad rzeczami poruszanymi. Lecz to byłoby niemożliwe, gdyby pierwszy motor był w jakiś sposób związany z rzeczą poruszaną czy to jako jej forma, czy to jako jej siła. Wobec tego pierwszy motor nie może być ani formą ciała, ani jego siłą ${ }^{74}$.

13. Z tezy rozdziału XVII wyprowadza Tomasz w rozdziale XVIII wniosek, że pierwszy motor jest nieskończony co do swej istoty, to znaczy, że nie jest w żaden sposób ogran i c zony (quod nullo modo finitur). Oto rozumowanie Tomasza:

Żaden akt nie jest ograniczony jak tylko przez możność, która go przyjmuje. Stwierdzamy bowiem, że formy są ograniczane według możności materii. Jeżeli więc pierwszy motor jest aktem bez domieszki możności, gdyż ani nie jest formą jakiegoś ciała, ani nie jest siłą zawartą w ciele — to motor ten musi być bytem nieskończonym.

Tego dowodzi również porządek, jaki występuje wśród rzeczy. Im bowiem jakieś byty są wznioślejsze (sublimiora), tym są większe w przysługującej im mierze. Również pierwiastki, które są wyższe, posiadają większe rozmiary i odznaczają się prostotą. A ciało niebieskie najwyraźniej przekracza całą masę (totam quantitatem) pierwiastków. Wobec tego trzeba przyjąć, że nieskończoną ilość posiada na swój sposób to, co między wszystkimi bytami świata ma pierwszeństwo, i czego nic wyprzedzać nie może. Stąd też nie powinno nas dziwić, że to, co jest pojedyncze i nie jest zdeterminowane ilościowo, odznacza się nieskończonością i swoją niezmierzonością (sua immensitate) przewyższa wszelką ilość ciał, skoro nasz umysł, który jest niecielesny i pojedynczy, przekracza siłą swego poznania ilość wszystkich ciał i wszystkie je współobejmuje. Tym

${ }^{74} \mathrm{Z}$ powyższych przesłanek Tomasz wyprowadza jesizcze trzeci wniosek, że pierwszy motor nie jest ciałem. 
bardziej to, co jest pierwszym bytem w ogólności, swoją niezmierzonością przekracza i obejmuje wszystko.

14. W rozdziale XIX posuwa się Tomasz o krok dalej twierdząc, że pierwszy motor posiada nieskończoną moc (est infinitae virtutis).

To twierdzenie jest najpierw dla Akwinaty wnioskiem z tezy poprzedniego rozdziału. Jest bowiem tak, że moc jest dostosowana do istoty rzeczy, gdyż sposób działania odpowiada sposobowi bytowania. Jeżeli więc pierwszy motor jest według swojej istoty bytem nieskończonym, to musi być również nieskończony pod względem swej mocy.

Twierdzenie rozdziału XIX jest również dla Tomasza wnioskiem z tezy głoszącej, że pierwszy motor jest czystym aktem. To bowiem, co znajduje się w możności, posiada z tej racji moc receptywną i bierną, a o ile jest w akcie, posiada moc aktywną. To więc, co jest w możności tylko, mianowicie materia pierwsza, posiada nieskończoną moc do przyjmowania, nic nie uczestnicząc w mocy aktywnej. Im znów coś w stosunku do niej posiada charakter bardziej formalny, tym bardziej obfituje pod względem mocy działania. Dlatego też ogień jest między wszystkimi pierwiastkami najbardziej aktywny. A pierwszy motor, który jest czystym aktem, nie mającym żadnej domieszki możności, przewyższa wszystkie byty nieskończoną mocą aktywną.

15. W rozdziale XX wyjaśnia Tomasz, że nieskończoność pierwszego motoru nie zawiera w sobie żadnej niedoskonałości.

To swoje twierdzenie uzasadnia najpierw tym, że pierwszy motor jest formą lub aktem, pozbawionym wszelkiej materii czy możności. Niedoskonałość przypada rzeczom, o ile posiadają materię, natomiast wszelka doskonałość pochodzi od formy. Ponieważ pierwszy motor jest z tej racji bytem nieskończonym, że jest tylko formą lub aktem, wolnym od wszelkiej domieszki materii czy możności, dlatego jego nieskończoność stanowi najwyższą doskonałość.

Twierdzenie, że nieskończoność pierwszego motoru jest jego najwyższą doskonałością, uzasadnia Tomasz jeszcze w inny sposób: Chociaż w jednym i tym samym, co przechodzi z niedoskonałości do doskonałości, najpierw występuje to, co jest niedoskonałe, a potem to, co jest doskonałe, bo na przykład najpierw jest ktoś chłopcem, a dopiero później mężem dojrzałym - to jednak to, co jest niedoskonałe, musi mieć początek w tym, co jest doskonałe. Wszak dziecko rodzi się tylko z męża, a nasienie wywodzi się ze zwierzęcia lub rośliny. Wobec tego to, co z natury swojej wyprzedza wszystkie byty dzięki temu, że je wprawia w ruch, musi być od nich doskonalsze. 
16. W rozdziale XXI precyzuje Tomasz myśl poprzedniego rozdziału dowodząc, że wszelka doskonałość jaka występuje w rzeczach otaczającego nas świata, znajduje się w pierwszym motorze i to w stopniu najwyżsym. Na rzecz tej tezy wysuwa d w a dowody.

Dowód pierwszy: Wszystko, co porusza inne byty do jakiejś doskonałości, posiada najpierw w sobie tę doskonałość. I tak, nauczyciel sam najpierw posiada wiedzę, którą innym przekazuje. Jeżeli więc coś jest pierwszym motorem, który wszystkie inne byty porusza, by osiągnęły właściwą sobie doskonałość, to $\mathrm{w}$ tym motorze muszą preegzystować w stopniu najwyższym (superabundanter) wszystkie doskonałości rzeczy.

Dowód drugi: Jeżeli jakiś byt, posiadający określoną doskonałość, jest pozbawiony innej doskonałości, to byt ten ogranicza się do pewnego rodzaju lub gatunku. Lecz to, co mieści się w obrębie pewnego gatunku lub rodzaju, nie może posiadać istoty nieskończonej, gdyż ostatnia jego cecha wyróżniająca (ultima differentia), dzięki której należy do danego gatunku, ogranicza (terminat) jego istotę. Jeżeli więc istota pierwszego motoru jest nieskończona, jest rzeczą niemożliwą, żeby ten motor posiadał jedynie doskonałość należącą do określonego rodzaju lub gatunku, a innych doskonałości był pozbawiony. Pierwszy motor musi posiadać w sobie doskonałości wszystkich rodzajów lub gatunków.

17. Nauka Tomasza o doskonałościach pierwszego motoru znajduje dopełnienie $\mathrm{w}$ tezie rozdziału XXII, według której w wy mien i o n y m motorze wszystkie doskonałości są realnie czymś jedny $m$ (unum secundum rem).

$\mathrm{Z}$ dwu dowodów, jakie Tomasz wysuwa na poparcie tej tezy, uwzględnię tylko pierwszy dowód, gdyż on jedynie jest wyrazem dalszego uszczegółowienia treści pojęcia pierwszego motoru. Oto tok myślowy tego dowodu:

Pierwszy motor jest bytem pojedynczym. Tam znów, gdzie jest pojedynczość, nie może występować wielość cech ${ }^{75}$. Jeżeli więc $\mathrm{w}$ pierwszym motorze znajdują się doskonałości wszystkich bytów, jest rzeczą niemożliwą, żeby między tymi doskonałościami zachodziła różnica realna. Musimy więc przyjąć, że te doskonałości stanowią jedno w pierwszym motorze.

18. Z tezy o braku realnej różnicy między doskonałościami pierwszego motoru wyprowadza Tomasz w rozdziale XXIII wniosek, że w ty $\mathrm{m}$ motorze nie ma żadnej przypadłości.

Jeżeli w pierwszym motorze - rozumuje Akwinata - wszystkie dos-

75 Tomasz pisze: „ubi autem est simplicitas, diversitas eorum quae insunt esse non pates". 
konałości są czymś jednym, a do doskonałości należy istnienie, działanie i inne tego rodzaju cechy, to w wymienionym motorze wszystkie te cechy są tym samym co jego istota, tak, że nie ma w nim żadnej przypadłości.

Do tego samego wniosku dochodzi również Tomasz, biorąc za punkt wyjścia nieskończoność pierwszego motoru: To, co jest nieskończone, nie może być doskonałością, do której można by coś dodać. Jeżeli zaś dany byt posiada doskonałość, która jest jego przypadłością, to, ponieważ każda przypadłość dodaje coś do istoty, do istoty tego bytu może być dodana jakaś doskonałość. Wobec tego w istocie takiego bytu nie mieści się nieskończona doskonałość. Lecz wyżej zostało udowodnione, że pierwszy motor odznacza się w swojej istocie nieskończoną doskonałością. Z tej też racji nie może w nim występować żadna doskonałość przypadłościowa, lecz cokolwiek w nim jest, jest jego substancją.

Tezę o braku jakiejkolwiek przypadłości w pierwszym motorze przyjmuje jeszcze Tomasz na tej podstawie, że temu motorowi przysługuje najwyższa pojedynczość, że jest on aktem czystym i pierwszym wśród bytów: Jedną z odmian złożenia jest zróżnicowanie na podmiot i jego przypadłości. Lecz to, co jest podmiotem, nie może być czystym aktem, gdyż przypadłość jest pewną formą lub aktem podmiotu. Zawsze także to, co jest per se, jest wcześniejsze od tego, co jest per accidens. Lecz w takim razie, biorąc pod uwagę powyższe trzy założenia, trzeba powiedzieć, że w pierwszym motorze nie ma niczego, co by miało charakter przypadłości.

19. W rozdziale XXVIII udowadnia Tomasz, że pierwszy motor jest bytem obdarzonym umysłem ${ }^{76}$. Dowody jego za tą tezą są następujące:

a) W pierwszym motorze preegzystują w sposób najdoskonalszy wszystkie doskonałości bytów, jakie tylko istnieją. Lecz między wszystkimi doskonałościami poznanie intelektualne zajmuje najprzedniejsze miejsce $\mathrm{z}$ tej racji, że jestestwa obdarzone tym poznaniem są doskonalsze (potiores) od tych, które tego poznania są pozbawione. Wobec tego pierwszy motor musi być bytem uzdolnionym do poznania intelektualnego.

b) Zostało wyżej udowodnione, że pierwszy motor jest czystym aktem, bez żadnej domieszki możności. Ponieważ materia jest bytem w możności, wobec tego pierwszy motor jest całkowicie wolny od materii. Lecz wolność od materii jest przyczyną intelektualności (causa intellectualitatis), jak o tym świadczy okoliczność, że formy materialne

${ }^{76}$ Pominąłem rozdziały XXIV-XXVII, gdyż one przez swą specyficzną tematykę, dotyczącą imion Bożych, nie posuwają naprzód dedukcji atrybutów pierwszego motoru. 
stają się aktualnymi przedmiotami umysłu (intelligibiles actu) dzięki temu, że zostają wyabstrahowane $\mathrm{z}$ materii i warunków materialnych.

c) Umysł jest tym, co popychając poszczególne byty do ruchu, posługuje się nimi jako narzędziami. Wobec tego pierwszy motor, który używa wszystkich innych bytów jako swoich narzędzi, musi być bytem obdarzonym umysłem.

20. Rozdziały XXIX-XXXI stanowią uzupełnienie myśli poruszonych w rozdziale XXVIII.

I tak, najpierw w rozdziale XXIX stwierdza Tomasz, że w pierwszym motorze poznanie umysłowe (intellectio) nie występuje nigdy jako możność lub jako stała sprawnośc, lecz jest zawsze aktem. Jako rację tego stanu rzeczy wymienia Tomasz okoliczność, że w pierwszym motorze nic nie jest w możności, lecz wszystko jest w akcie.

Z tezy, że w pierwszym motorze poznanie umysłowe jest wyłącznie w akcie, wyprowadza Tomasz wniosek, że w tym poznaniu nie ma żadnego następstwa czasowego. Gdy bowiem jakiś umysł sukcesywnie poznaje liczne przedmioty - rozumuje Tomasz - to gdy jeden przedmiot poznaje w akcie, drugi przedmiot musi poznawać w możności tylko. Natomiast między tymi przedmiotami, które są dane naraz, nie ma żadnego następstwa czasowego. Jeżeli więc pierwszy motor niczego nie poznaje w możności, to w jego poznaniu nie występuje żadne następstwo czasowe. To za sobą pociąga, że wszystko, co ten motor poznaje, naraz poznaje, a dalej, że niczego nowego nie p o z n a j e ${ }^{77}$. Jeżeliby bowiem [jego] umysł poznawał coś nowego, wpierw byłby poznającym w możności. Trzeba także przyjąć, że umysł pierwszego motoru nie poznaje w sposób dyskursywny, jak nasz umysł. Poznanie dyskursywne ma miejsce wtedy, gdy dochodzimy od rzeczy znanej do poznania rzeczy nieznanej, to jest takiej rzeczy, której przedtem nie poznawaliśmy w akcie. Taki zaś proces nie może zachodzić w umyśle pierwszego motoru.

Tomasz jest zdania, że pierwszy motor nie poznaje przez inną podobiznę (per aliam speciem), jak przez swoją ist ot ę. Tej tezy dowodzi w rozdziale XXX w następujący sposób:

Każdy umysł, który poznaje przez podobiznę różną od siebie, pozostaje do niej w takim stosunku, jak możność do aktu, gdyż podobizna umysłowa (species intelligibilis) jest doskonałością umysłu, doprowadzającą do poznania aktualnego. Jeżeli więc w pierwszym motorze nic nie jest w możności, gdyż jest on czystym aktem, to jego poznanie musi dokonywać się nie przez podobiznę różną od niego, lecz przez jego istotę. A w

77 Tomasz pisze: „quod nihil de novo intelligat”. 
dalszej konsekwencji trzeba powiedzieć, że be z pośrednim i głównym przedmiotem poznania pierwszego motoru jest o $n$ s a m. Istota bowiem danej rzeczy prowadzi bezpośrednio do poznania tej rzeczy, do której należy. Wszak przez definicję człowieka jest poznawany człowiek, a przez definicję konia - koń. Jeżeli więc pierwszy motor jest bytem poznającym przez swoją istotę, to bezpośrednim i głównym przedmiotem jego poznania jest on sam. A ponieważ on sam jest swoją istotą, to w nim podmiot poznający, środek poznania i przedmiot poznania są całkowicie jednym i ty m s a m y m.

Zamknięciem wywodów o poznaniu umysłowym pierwszego motoru jest teza rozdziału XXXI, że pierwszy motor jest swoim poznaniem umysłow ym (est suum intelligere). Tezę tę udowadnia Tomasz najpierw w następujący sposób:

Jeżeli poznanie umysłowe jest drugim aktem (actus secundus) - aktem bowiem pierwszym jest sam umysł lub wiedza - to umysł, który nie jest swoim poznaniem umysłowym, pozostaje w stosunku do tego poznania, jak możność do aktu. Zawsze bowiem, jeżeli idzie o jeden i ten sam byt, wzajemny stosunek możności i aktu układa się tak, że to, co jest wpierw, jest w możności do tego, co przychodzi później. Lecz w pierwszym motorze ze względu na to, że jest on czystym aktem, nie może znajdować się coś, co byłoby w relacji do czegoś drugiego, jak możność do aktu. Wobec tego pierwszy motor musi być swoim poznaniem umysłowym.

Do tego samego wniosku prowadzi jeszcze - zdaniem Tomasza następujące rozumowanie: Umysł pozostaje $w$ pewien sposób do poznania umysłowego tak, jak się ma istota do istnienia. Lecz pierwszy motor jest bytem poznającym przez swoją istotę, istota zaś jego jest jego istnieniem, wobec tego jego umysł jest jego poznaniem umysłowym.

21. Osobną grupę rozdziałów stanowią w Compendium theologiae rozdziały XXXII-XXXIV. W nich Tomasz zajmuje się wolą pierwszego motoru.

I tak, w rozdziale XXXII dowodzi, że w pi e r w s y m m o t or ze występuje chcenie rozumne. Wszak pierwszy motor, który jest dobrem doskonałym, poznaje samego siebie. Dobro poznane jest z konieczności miłowane. Ta miłość dokonuje się przez akt woli. Wobec tego w pierwszym motorze występuje chcenie rozumne. A dalej, umysł pierwszego motoru może poruszać inne byty tylko za pośrednlctwem pożądania. Lecz pożądanie, które ma swe źródło w poznaniu umysłowym, jest aktem woli. Wobec tego w pierwszym motorze występuje chcenie rozumne. 
W rozdziale XXXIII Tomasz wysuwa tezę, że w o la pi e r w s z e g o motoru nie jest czymśśćnym od jego umysłu. Oto rozumowanie Akwinaty.

Dobro poznane, będąc przedmiotem woli, porusza ją i jest jej aktem, jej doskonałością. Lecz w pierwszym motorze nie różni się między sobą czynnik poruszający i to, co jest poruszane, akt i władza, doskonałość i to, co jest udoskonalane. Wobec tego wola pierwszego motoru musi być samym dobrem poznanym. Ponieważ umysł pierwszego motoru jest tym samym co jego istota, dlatego też jego wola nie jest czymś różnym od jego umysłu i od jego istoty. A dalej, wśród doskonałości pierwsze miejsce zajmują umysł i wola, czego dowodem jest okoliczność, że występują zawsze w bytach najszlachetniejszych. Lecz w pierwszym motorze wszystkie doskonałości są czymś jednym i utożsamiają się z jego istotą. Z tej racji umysł $\mathrm{i}$ wola są $\mathrm{w}$ pierwszym motorze tym samym co jego istota.

W rozdziale XXXIV wykazuje Tomasz, że wola pierwszego motoru jest samym jego chceniem rozumnym. Oto, w jaki sposób:

Wola w pierwszym motorze jest tym samym, co dobro chciane przez niego. Lecz to nie mogłoby mieć miejsca, gdyby chcenie wymienionego motoru nie było tym samym co jego wola, gdyż chcenie występuje w woli w następstwie działania jej przedmiotu. Wobec tego wola pierwszego motoru jest swoim chceniem. A dalej, wola tego motoru jest tym samym co jego umysł $\mathrm{i}$ jego istota. Umysł zaś pierwszego motoru jest swoim poznaniem umysłowym, a jego istota jest swoim istnieniem. Wobec tego wola jest jego chceniem rozumnym.

22. Argumentacja kinetyczna za istnieniem Boga, podana w rozdziale III dziełka Compendium theologiae, domaga się nowych uwag krytycznych jedynie ze względu na próbę udowodnienia pierwszej tezy kosmologicznej - arystotelesowskiej zasady ruchu - na drodze indukcji (prawdopodobnie zupełnej) z poszczególnych danych empirycznych, gdyż tylko ten sposób uzasadnienia stanowi coś nowego w stosunku do pierwszej wersji argumentacji z ruchu Sumy filozoficznej, jak i w odniesieniu do rozumowania z Sumy teologii. Otóż jest rzeczą aż nazbyt widoczną, że ten z zamierzenia indukcyjny dowód pierwszej tezy kosmologicznej nie ma nic wspólnego z uogólnie$\mathrm{n}$ i e m faktó w. Wiąże się on z obaloną dawno przyrodniczą częścią fizyki arystotelesowskiej. A jeżeli w ten sposób należy ocenić podane przez Tomasza uzasadnienie pierwszej tezy kosmologicznej, to d a ls z y ciąg jego argumentacji kinetycznej-dowód drugiej tezy z zakresu filozofii przyrody i końcowy wniosek redukcyjny o istnieniu 
pierwszego motoru - będziemy odnosili nie do rzeczywistegokosmosu, lecz do konstrukcji pojęciowych teorii sfer geocentrycznych Eudoxosa, przyjmowanej przez Stagirytę i Akwinatę.

23. Mogłoby się wydawać, że przy takiej ocenie argumentacji kinetycznej z Compendium theologiae nie jest już celowe pytanie się o wartość przedstawionej $\mathrm{w}$ tym dziełku dedukcji atrybutów pierwszego motoru. Skoro jednak, jak to jest widoczne z całości naszych uwag krytycznych o różnych dotychczasowych próbach argumentacji kinetycznej, można wykazać istnienie pierwszego motoru, będącego Bogiem, wychodząc z ruchu lokalnego, dlatego jest sensowne przebadanie, czy Tomasz, biorąc za punkt wyjścia ten ruch, zdołał, niezależnie od swoich powiązań z nieadekwatną przyrodniczą wizją wszechświata, ảojść przez analizę treści pojęcia pierwszego motoru do wyodrębnienia atrybutów, które trzeba przypisać Bogu. Przy tych naszych poszukiwaniach będziemy mogli korzystać z uwag, jakie wysunęliśmy w odniesieniu do dwu końcowych twierdzeń pierwszego wariantu argumentacji kinetycznej z Sum. c. Gent. ${ }^{78}$, gdyż bazę empiryczną tej argumentacji stanowi, podobnie jak $\mathrm{w}$ Compendium theologiae, ruch cial, i to prawdopodobnie sam ich ruch lokalny.

24. O wartości przeprowadzonej przez Tomasza dedukcji atrybutów pierwszego motoru decyduje jej pierwszy etap, na którym usiłuje się dowieść, że wymieniony motor jest c ałkowicie ni e r u chomy. Wszystkie bowiem jego dalsze atrybuty są ustalane w drodze bezpośredniego lub pośredniego wnioskowania z tezy głoszącej, że jest on całkowicie nieruchomy. Wprawdzie na niektórych etapach dedukcji ma miejsce odwoływanie się bezpośrednie do istoty pierwszego motoru, ale to odwoływanie się jest zawsze czymś dodatkowym, bo czynnikiem zasadniczym jest pośrednie powiązanie danej tezy z twierdzeniem o całkowitej nieruchomości pierwszego motoru. Czy więc Tomasz wykazał biorąc za punkt wyjścia swych wywodów ruch lokalny, że ten motor odznacza się wskazanym atrybutem?

Jak pamiętamy, Tomasz wysunął w tym przedmiocie dwa dowody. W pierwszym dowodzie chodzi o myśl, że pierwszy motor dlatego musi być całkowicie nieruchomy, bo gdyby był poruszany, byłby poruszany albo przez inny byt, albo przez samego siebie, a tymczasem jedno i drugie nie daje się pogodzić z istotą pierwszego motoru, dokładniejjak wynika z całokształtu wywodów Akwinaty - z istotą motoru pierwszego pod każdym względem, czyli pozostającego w relacji przyczynowania do wszystkiego, co w kosmosie ma charakter dynamiczny. Dodatko-

78 Zob. w niniejszym artykule próby oceny tej argumentacji. 
wo tylko Tomasz przechodzi przy wykluczeniu drugiej możliwości — możliwości poruszania się przez siebie samego, wziętej w jednej jej wersji — do innego rodzaju argumentacji, w której odwołuje się do zasady sprzeczności w ujęciu ontologicznym.

Zasadniczy tok jego argumentacji nie jest jednak przekonywający, nawet gdy go oderwiemy od teorii sfer geocentrycznych Eudoxosa. Gdy szukamy ostatecznego wytłumaczenia dla znanego nam z doświadczania ruchu lokalnego, wziętego $\mathrm{w}$ jego rzeczywistości fizycznej ${ }^{79} \mathrm{i} \mathrm{w}$ powiązaniu przyczynowym $\mathrm{z}$ innymi ruchami lokalnymi, to niezależnie od tego, jaki bralibyśmy pod uwagę przyrodniczy model kosmosu, dojdziemy tylko do pierwszego motoru, który nie jest poruszany ruchem lokalnym ze strony innego bytu. Ale taki motor, nieruchomy pod względem ruchu lokalnego, mógłby być poruszany i n $\mathrm{n}$ y $\mathrm{m}$ g atunkiem ruchu w sensie ścisłym, takim jak poruszanie przez siebie sa mego. Odpada wprawdzie przypadek, w którym pierwszy motor byłby pod tym samym względem czynnikiem poruszającym i rzeczą poruszaną - argumentacja Tomasza przeciw takiej możliwości jest przekonywająca całkowicie - ale mogłoby być tak, żeby rzeczony motor stanowił pod jednym względem czynnik poruszający, a pod innym rzecz poruszaną. Tego przypadku Tomasz nie zdołał efektywnie wykluczyć, gdyż nie dowiódl, że jego pierwszy motor, wolny od ruchu lokalnego, musiałby również być pierwszym motorem, o ile jest pewną całością (secundum se). Ten motor mógłby być poruszany nie tylko innym gatunkiem ruchu $w$ znaczeniu ścisłym niż ruch lokalny, ale mógłby także podlegać takiemu ruchowi w sensie nieścisłym, metaforycznym, jakim są czynności myślenia i chcenia rozumnego, wy woływane przez transcendentne w stosunku do nich przedmioty. Motor z Compendium theologiae mógłby więc nie być pod każdym względem pierwszym motorem. A tymczasem do skuteczności analizowanego obecnie dowodu Akwinaty jest potrzebne faktyczne istnienie bytu, który byłby pierwszym motorem bez żadnych ograniczeń.

Drugi dowód, jaki Tomasz przytoczył za całkowitą nieruchomością pierwszego motoru, nie jest również przekonywający.

Akwinata twierdzi najpierw, że każdy ruch zdaje się pochodzić od czegoś nieruchomego, to jest od tego, co nie jest poruszane według tego samego gatunku ruchu. Traktuje więc początkowo tę tezę jako zdanie prawdopodobne. Zaraz jednak nadaje wymienionej tezie wydźwięk kategoryczny, gdy odwołuje się do doświadczenia, które jego zdaniem - uczy nas, że zmiany dokonujące się na Ziemi wywodzą

79 A więc bez jego analizy przy pomocy pojęć możności i aktu. 
się, jako od swego pierwszego motoru, od ciała niebieskiego, nie poruszanego według tego samego gatunku zmiany, ruchu. I w oparciu o te dane „doświadczenia” dochodzi do k a t e gor y c z ne go wni osk u, że to, co jest pierwszą zasadą wszelkiego ruchu, musi być całkowicie nieruchome.

Ten wniosek nie jest jednakże uzasadniony $z$ dwu powodów. Najpierw dlatego, że, jak zostało uwidocznione przy ocenie pierwszego dowodu, Tomasz nie wykazał, że pierwszy motor, o którym pisze, jest pierwszą zasadą ws zelkiego ruchu. Rozpatrywany obecnie wniosek nie jest również uzasadniony $\mathrm{z}$ tej racji, że został wyprowadzony nie w oparciu o dane doświadczenia, lecz w powiązaniu z nieadekwainą przyrodniczą wizją kosmosu.

25. Jeżeli Tomasz nie dowiódł, że rozpatrywany przez niego pierwszy motor jest całkowicie nieruchomy, to jego dalsza dedukcja atrybutów tego motoru staje pod znakiem zapytania.

I tak, trzeba zauważyć, że jeżeli pierwszy motor Akwinaty mógłby być poruszany innym gatunkiem ruchu $\mathrm{w}$ znaczeniu ścisłym niż ruch lokalny, to mógłby być c i ałe m przynajmniej w części swojego bytu. Mógłby być także formą c i ała lub zaw a r tą w ni m siłą. A wtedy nie dałoby się dowieść jedyności tego motoru, jak to starałem się wykazać przy ocenie przedostatniego wniosku redukcyjnego pierwszej wersji argumentacji kinetycznej z Sumy filozoficznej. Nie dałoby się również dowieść tych atrybutów, których nie można pogodzić z byciem ciałem, jego formą lub siłą w nim się znajdującą. Są to atrybuty, o których jest mowa w rozdziałach V-XI i XV-XXIII Compendii theologiae. Jeżeliby dalej uwzględniło się treść rozdziałów XXVIII i XXXII tego dziełka, w których Tomasz pisze, że pierwszy motor jest obdarzony umysłem i wolą, to po przedstawionych zastrzeżeniach nie można byłoby powiedzieć, że w tym motorze poznanie umysłowe nie jest nigdy możnością lub stałą sprawnością, lecz zawsze aktem; że ten motor nie poznaje przez inną podobiznę jak przez swoją istotę i jest swoim poznaniem umysłowym; że jego wola nie różni się realnie od jego umysłu i jest samym jego chceniem rozumnym. A przy takich perspektywach nie widać, co w pierwszym motorze, mającym ostatecznie uzasadniać znany z doświadczenia ruch lokalny, mogłoby przemawiać za jego tożsamością z B og i e m. 


\section{UZUPEENIAJĄCE UWAGI KRYTYCZNE DO TOMASZOWYCH WARIANTÓW ARGUMENTACJI KINETYCZNEJ}

Po przeprowadzonych analizach krytycznych wysuniętych przez Tomasza $\mathrm{z}$ Akwinu form argumentacji kinetycznej narzuca się jeszcze potrzeba: 1) pełniejszego zbadania adekwatności arystotelesowskiego ujęcia filozoficznego ruchu $\mathrm{w}$ znaczeniu ścisłym oraz implikacji o charakterze dedukcyjnym i redukcyjnym tego ujęcia - implikacji zarówno przyrodniczych jak i z zakresu filozofii przyrody, a ostatecznie z dziedziny filozofii Boga; 2) rozpatrzenia poglądów fizyki współczesnej na temat relacji ruchu mechanicznego do materii i możliwości ich wykorzystania w jednej z dopuszczalnych form argumentacji kinetycznej; 3) dokładniejszego przeanalizowania od strony epistemologicznej i metodologicznej wspólczesnych form wymienionej argumentacji. Podejmując się tych trzech zadań dokonam częściowej korektury tego, co utrzymywałem w rozprawie Zagadnienie punktu wyjścia kinetycznej argumentacji za istnieniem Boga ${ }^{80}$, a także $\mathrm{w}$ pracy $Z$ zagadnien filozoficznego poznania Boga ${ }^{81}$.

$\S$ 1. Zagadnienie adekwatności arystotelesowskiego ujęcia ruchu w znaczeniu ścisłym i jego implikacji

1. Próby ostatecznego wytłumaczenia faktu ruchu znanego empirycznie należy rozpocząć od jego fil o z of i c z n e g o ujęcia. Jest to postulat metodologiczny o podstawowym znaczeniu dla argumentacji ex motu, który należy bezwzględnie podtrzymywać.

Przy uzasadnieniu wskazanego punktu wyjścia można nawiązać w pewien sposób do wywodów, z pomocą których Maritain ${ }^{82}$ zmierzał do wykazania, że, uprawiając filozofię przyrody, należy oprzeć się na tak zwanych faktach filozoficznych, to znaczy, na danych doświadczenia przednaukowego, a zwłaszcza naukowego, przemyślanych w świetle własnym filozofii, z pomocą jej pierwszych zasad, lub skonfrontowanych tylko z określonymi tezami kosmologii filozoficznej. Francuski myśliciel miał niewątpliwie rację, gdy utrzymywał, że porządek środków powinien odpowiadać porządkowi celów, i stąd fakty, którymi posługuje się filozofia przyrody, powinny być również z obrębu jej poznania ${ }^{83}$. Inspirując się

80 ,Studia Philosophiae Christianae", 4 (1968, nr 2) $75-111$.

81 S. $71-73$.

82 La philosophie de la nature - Philosophie et sciences 252-253; La philosophie de la nature - Essai critique sur ses frontières et son objet, 132-141; Science et sagesse, Paris 1935, 111; Quatre essais sur l'esprit dans sa condition charnelle, 224-225, 241-253; Distinguer pour unir, ou Les degrés du savoir, 113-116, 352-356. 136.

${ }^{83}$ La philosophie de la nature - Essai critique sur ses frontières et son objet,

Maritainową koncepcję oparcia filozofii przyrody na faktach ,filozoficznych" 
tymi wskazaniami metodologicznymi Maritaina powiemy, że gdybyśmy w przypadku kinetycznej argumentacji za istnieniem Boga wzięli za punkt wyjścia ruch w ujęciu fizykalnym, wprowadzilibyśmy do bazy wyjściowej naszej argumentacji obcy dla niej element treściowy, bo spoza obrębu szeroko rozumianej analizy ontologicznej przyrody, to jest analizy relatywnej do właściwego dla niej typu bytu.

Musimy starać się tylko o to, żeby ruch w takim czy innym rozumieniu filozoficznym nie różnił się materialnie od ruchu znanego nam $\mathrm{w}$ ujęciu potocznym i badanego $\mathrm{z}$ kolei $\mathrm{w}$ obrębie mechaniki. Powinien to być tylko wyodrębniony $\mathrm{w}$ drodze abstrakcji aspekt tego drugiego ruchu, wyrażony przy pomocy określonych pojęć filozoficznych. Wobec tego różnica między ruchem w jakimś ujęciu filozoficznym a ruchem w rozumieniu potocznym i fizykalnym powinna być - biorąc rzecz od strony poznawczego opanowania przyrody - różnicą pojęciową, 1og i c z n ą. Gdy o tej różnicy mówi się na gruncie realistycznej teorii poznania, nie przeocza się aspektów obiektywnych ruchu, które powinny znaleźć uwidocznienie w jego ujęciu ze stanowiska filozofii przyrody, a których nie uwzględnia się przy jego poznaniu przednaukowym i fizykalnym. Różnica, o której mówimy, nie jest więc czystą różnicą pojęciową, lecz różnicą pojęciową z podstawą w rzeczy (cum fundamento in re).

rozpatrzyłem krytycznie w pracach: Aktualne kontrowersje w zakresie prolegomenów do filozofii przyrody, „Zeszyty Naukowe KUL”, 3 (1960, nr 2) 25-30; Zagadnienie metody filozofii przyrody we wspótczesnej neoscholastyce, „Roczniki Filozoficzne", 9 (1961, z. 3) 5-36; Z teorii i metodologii filozofii przyrody, Poznań 1980, $124-148$.

Podtrzymując w zasadzie pozytywną ocenę stanowiska Maritaina przedstawioną w tych pracach, chciałbym zauważyć, że francuski tomista nie poruszył zagadnienia tak zwanych faktów filozoficznych w sposób dostatecznie uniwersalny, lecz uwzględnił jedynie przypadek, gdy już jesteśmy w posiadaniu jakiejś filozofii przyrody, a chodzi nam tylko o jej treściowe poszerzenie na danym odcinku w oparciu o nowe, nie uwzględnione dotąd fakty filozoficzne. Stąd też Maritainową koncepcję, dotyczącą faktów wyjściowych filozofii przyrody, należy tak uogólnić, by mogła znaleźć zastosowanie nie tylko przy dalszym rozwijaniu tej nauki, ale również przy jej zapoczątkowywaniu.

Ujęcie faktów wyjściowych fillozofii przyrody posiada jeszcze u Maritaina ten brak, że ich wyodrębnienie ma dokonywać się przy współudziale ,pierwszych zasad filozofii', dzięki którym zostaje uwydatniona ukryta w nich poitencjalnie wartość filozoficzna, dokładniej - wantość z zakresu kosmologii filozoficznej. Pisząc o ,pierwszych zasadach filozofii" (des principes premiers de la philosophie), Maritain miał zapewne na uwadze pierwsze zasady metafizyki, które mogą znaleźć zastosowanie do ontycznej strony przyrody. Ale sięgnięcie do filozofii bytu psuje jednolitość stanowiska francuskiego filozofa, gdyż zakłada w jakimś zakresie konieczność „odgórnego" budowania filozofii przyrody w oparciu o metafizykę. Tymczasem Maritain utrzymywał, że można dojść niezależnie od metafizyki do sformułowania filozofii przyrody, ,wziętej przynajmniej w jej wielkich określeniach istotnych" (prise du moins dans ses grandes déterminations essentielles). W związku z tym twierdzeniem należało szukać pierwszych zasad bytu w ramach poznania z zakresu kosmologii filozoficznej, a więc wziętych nie w ich najogólniejszym sformułowaniu, ale $\mathrm{w}$ zacieśnieniu do typu bytu właściwego przyradzie. 
2. Ze strony tomistycznej przyjmuje się powszechnie za Arystotelesem następującą filozoficzną definicję ruchu w znaczeniu ścisłym: Wymieniony ruch jest a k tem bytu istniejącego w możności jako w możności (actus possibilis inquantum est possibile) ${ }^{84}$. Ta definicja jest jednak określeniem eliptycznym, niezrozumiałym bez komentarza nawet dla tych, którzy znają treść arystotelesowskich pojęć możności i aktu. Z tego stanu rzeczy zdawał już sobie sprawę Piotr Hoenen ${ }^{85}$.

Ponieważ będę chciał zbadać adekwatność i implikacje typu redukcyjnego przytoczonej definicji, przypomnę dodawany do niej tradycyjnie komentarz, zacieśniający ją do pojęcia ruchu lokalnego, by skrócić wyjaśnienia. Głębsze przemyślenie iego komentarza narzuca się jako nakaz chwili wobec wysuwanych aktualnie $\mathrm{z}$ niektórych stron nie dość adekwatnych interpretacji.

Według filozofii tomistycznej ruch lokalny zasadza się na przechodzeniu z możności zajęcia pewnego miejsca do jego faktycznego zajęcia. Nazywając faktyczne zajęcie miejsca ,aktem doskonałym" (actus perfectus, actus ultimus) ciała, a jego zdolność do faktycznego zajęcia miejsca ,czystą możnością” (potentia pura), pojmuje się ruch lokalny ze strony wymienionej filozofii jako stadium pośrednie między czystą możnością a aktem doskonałym. Czysta możność do zajęcia danego miejsca nie stanowi jeszcze ruchu lokalnego. Gdy ciało zajmie definitywnie jakieś miejsce, gdy więc jest $\mathrm{w}$ akcie doskonałym, jego ruch już się skończył. Ruch lokalny dokonuje się wtedy, gdy ciało weszło w stan przejściowy między czystą możnością zajęcia określonego miejsca a jego aktualnym zajęciem. Ten stan przejściowy jest nazywany ,aktem”, gdyż ruch lokalny jest pewną rzeczywistością. Jest to jednak akt niedoskonały (actus imperfectus), bo nie stanowi jeszcze ostatecznego osiągnięcia ciała, lecz jest tylko dążeniem do pewnego kresu (via et fieri ipsius termini). Nazywając ruch lokalny aktem niedoskonałym, chce się powiedzieć, że ciało, które znajduje się w ruchu lokalnym, jest częścią w akcie, a częścią w możności (partim in actu, partim in potentia) ${ }^{86}$.

84 Jest to thumaczenie $\mathrm{Tomasza} \mathrm{z}$ A kwinu (Commentaria in octo libros Physicorum Aristotelis w cyt. wydaniu, in lib. III lect. II, s. 106, n. 8) definicji

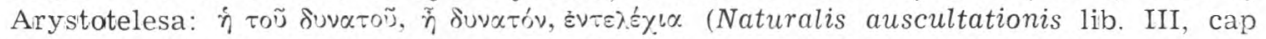
I, w wyd. paryskim A. Firmin-Didot, II, s. 274, w. $30-31$ ).

85 Cosmologia, 224.

86 Przedstawiając arystotelesowsko-tomistyczną koncepcję ruchu lokalnego, wzoruję się na tekście Jana od św. Tomasza z jego Cursus philosophicus thomisticus, vol. II, Phil. Natur. I. pars, qu. XIV, a. 1 (w wyd. B. Reisera s. 293, b. $33-44)$.

Szczególowych analiz ruchu ściśle rozumianego dokonali w duchu filozofii perypatetyczno-tomistycznej $\mathrm{m}$. in. H o e n e n (dz. cyt., 213-237), S elva g g i (Cosmologia, 67-78), Józef de Tonquédec, 1e partie: La nature en gínéral, $3^{\mathrm{e}}$ fasc. Paris 1959, 3-56) i St. A d a m c zy k (Arystotelesowa koncepcja ruchu, „Roczniki Filozoficzne", 17 (1969, z. 3) 5-25). 
3. Przechodząc do zagadnienia a dekwa t n ości arystotelesowskiej definicji ruchu w znaczeniu ścisłym, musimy zauważyć przy ograniczeniu się do ruchu lokalnego, że do cial poruszających się ruchem należącym do tego gatunku możemy odnosić w pewnych granicach pojęcia możności i aktu. I tak, trzeba powiedzieć, że nic nie stoi na przeszkodzie, by zdolność ciała do faktycznego zajęcia jakiegoś miejsca nazywać „,czystą możnością", a faktyczne zajęcie miejsca ,aktem doskonałym”, gdy mamy na uwadze formalne (zewnętrzne) terminy a quo i ad quem ruchu lokalnego. Możemy także twierdzić, że ciało, które porusza się ruchem lokalnym, częścią jest w akcie, a częścią w możności. Jest aktem w stosunku do swej uprzedniej możności wejścia w ruch lokalny i w porównaniu $\mathrm{z}$ dotychczasowym etapem tego ruchu; jest natomiast $\mathrm{w}$ możności w relacji do całej reszty ruchu lokalnego, która dopiero będzie zrealizowana. Jeżeli przy tych określeniach mamy na uwadze następujące po sobie $\mathrm{w}$ czasie, nie powiązane $\mathrm{z}$ sobą genetycznie względne aspekty ciała poruszającego się ruchem lokalnym, jesteśmy w pełnej zgodzie $\mathrm{z}$ faktycznym stanem rzeczy.

Ale, stosując do ruchu lokalnego a (także do innych postaci ruchu w znaczeniu ścisłym) pojęcia możności i aktu, ni e d o chodzimy do

Analizy przeprowadzone przez Krąpca odbiegają częściowo od wzorca przyjmowanego przez wymienionych autorów. Dla profesora lubelskiego ruchem $\mathrm{w}$ znaczeniu ścisłym jest jakakolwiek zmiana, nawet zmiana momentalna. Zob. Z zagadnién filozoficznego poznania Boga, Kraków 1978, s. 39 n.

Podjęto również u nas próbę wyrażenia językiem fizyki sensu terminów „potencjalność" i „aktualność", występujących w arystotelesowskiej definicji ruchu. Sugestie w tym kierunku przedstawił Z. Chyliński na sympozjum fillozoficznym, które odbyło się w styczniu 1968 r. w Krakowie, w arcybiskupiej rezydencji Kard. Wojtyły. „Wydaje się - mówił Chyliński - że potencjalność to tyle, co rozwój [systemu zostawionego sobie], który jest opisany w fizyce kwantowej funkcją falową. Natomiast aktualność to tyle, co każdy pomiar, czyli to, co się mądrze nazywa redukcją pakietu falowego, a proces redukcji pakietu falowego można zamodelować na aktualizacji, która nie może wynikać z żadnego kauzalnego równania tyipu Schrödingera, które rządzi rzeczywistością potencjalną". Wracając jeszcze raz do swej fizykalistycznej interpretacji Chyliński powiedzial: „Arystoteles [...] rozróżnił [...] dosyć spekulatywnie koncepcję potencji, że cząstka może się znaleźć gdzieś. [...] Dzisiejsza fizyka zmaterializowała to pojęcie potencji. Mianowicie funkcja stanu, rządzona kauzalnym równaniem typu Schrödingera, stanowi to wszystko co się może stać. Cząstka może przechodzić równocześnie przez dwadzieścia szpar. Natomiast kwestia aktualizacji, to jest to, co ja stwierdzam, a to stwierdzenie nie może się odbywać bez pomiaru. Stwierdzenie, że cząstka przeszła tędy, a nie gdzie indziej, jest redukcją pakietu falowego". (W: E. Morawiec, Sympozjum filozoficzne poświęcone analizie punktu wyjścia kinetycznego $i$ teologicznego argumentu na istnienie Boga, 231-232).

Interpretacja fizykalistyczna Chylińskiego jest intenesująca, niemniej jednak trudno ją uznać za adekwatną. I tak, potencjalność Arystotelesa nie jest tym samym, co rozwój systemu zostawionego sobie, który to rozwój w mechanice kwantowej opisujemy przy pomocy funkcji falowej. Rozwój, jedna $z$ form ruchu, jest u Arystotelesa aktualizacją potencjalności, a nie samą potencjalnością. Również aktualność, o jakiej jest mowa $w$ arystotelesowskiej definicji ruchu, to nie to, co można stwierdzić z pomocą pomiaru, że cząsteczka jest tu, a nie tam, że przeszła tędy, a nie gdzie indziej. W przypadku ruchu aktualność stanowi jego cząsteczkowy aspekt konstytutywny. 
jego pełnej charakterystyki z pozycji filozofii przyrody. Swiadczy o tym to, że musimy posłużyć się innymi jeszcze pojęciami. I tak, wprowadzamy pojęcie przejści a (transitus) z możności do aktu lub po prostu pojęcie przejścia od jednego do drugiego, jak to ma miejsce, kiedy wprowadza się pojęcie zmiany jako pojęcie ogólniejsze $\mathrm{w}$ stosunku do pojęcia ruchu ściśle rozumianego ${ }^{87}$. Wyjaśniamy $\mathrm{z}$ Hoenenem ${ }^{88}$, że ów ruch jest to via et fieri ipsius termini, via ad esse, via (existentis) ad esse existentiae, fieri extensum et continuum, continuum fluens, actus fluens. Te dodatkowe wyjaśnienia nie byłyby potrzebne, gdyby przy pomocy pojęć aktu i możności można było w pełni, bez reszty, wyrazić naturę ruchu w znaczeniu ścisłym. Wyjaśnienia te mają przy tym tę słabą stronę, że stanowią nieprzekraczalny pułap w naszym poznaniu wymienionego ruchu. Nie można ich rozwinąć w wyjaśnienia bardziej precyzyjnie. Wszak pojęcia stawania się, przechodzenia z jednego do drugiego, stanowią pojęcia dla nas definitywnie pierwotne, w których treści nie wychodzimy poza dostrzeżenie elementu wspólnego naszych konkretnych doświadczeń, wziętych pod względem ich zmienności.

Czy niemożność pełnego wyrażenia natury ruchu w znaczeniu ścisłym przy pomocy pojęć aktu i możności przekreśla lub nie przekreśla przydatności arystotelesowskiej definicji dla argumentacji kinetycznej w ogóle, a przynajmniej dla pewnego jej typu - to wyjaśni się nam w trakcie wyodrębnienia implikacji tej definicji.

4. Badania implikacji typu dedukcyjnego lub redukcyjnego, jakie może posiadać arystotelesowska definicja ruchu ściśle rozumianego, rozpoczynam od jej ewentualnych implikacji przyrodniczych. Chodzi mi najpierw o to, czy ta definicja implikuje redukcyjnie tezę, ż ciała są przez siebie nieruchome, a mogą być tylko od zewnątrz wprawiane w ruch.

$\mathrm{Na}$ postawione pytanie trzeba odpowiedzieć negatywni e. Jeżeli utrzymujemy, że ruch w znaczeniu ścisłym zasadza się na coraz dalszym, ale nigdy pełnym aktualizowaniu możności, zakładamy tylko tyle, że rozciągłość przysługuje podmiotowi tego ruchu i jego otoczeniu. W ramach tego, co byłoby nierozciągłe, ruch mógłby być tylko zmianą momentalną. Gdy więc w odniesieniu do tego, co stanowi tworzywo rozciągłe, mówimy, że ruch ściśle rozumiany jest w jego obrębie aktem bytu istniejącego w możności jako w możności, wówczas mówimy o czymś, co mogłoby mieć miejsce zarówno wtedy, gdy ów ruch nie należałby do ujętej empiriologicznie istoty materii, jak i wtedy, gdy należałby do niej. W jednym bowiem i drugim przypadku wchodziłby $w$ gre ten sam

${ }^{87} \mathrm{H}$ o e nen, $d z$. cyt., s. 213 , n. 144 , s. $218-220$, n. 152, s. 222, n. 155 ; S e lv a g g i, dz. cyt., 69 .

${ }_{88} D z$. cyt., s. 215 , n. 145 , s. 220 , n. 152 , s. 226 , n. 157 , s. 234 , n. 161, s. 237 , n. 162. 
czynnik decydujący o tym, że ruch w znaczeniu ścisłym jest ciągiem sukcesywnych, coraz to dalszych realizacji bytowych. Wobec tego arystotelesowską definicją tego ruchu mógł posługiwać się w płaszczyźnie filozofii przyrody nie tylko zwolennik dawnej, statycznej koncepcji materii. Tę definicję może podejmować $\mathrm{z}$ pozycji kosmologii filozoficznej również i ten, kto $\mathrm{w}$ oparciu o fizykę współczesną utrzymuje, że jest prawie pewne, iż taki ruch ściśle rozumiany, jakim jest ruch mechaniczny, należy do empiriologicznie potraktowanej istoty materii.

Ale gdy zwolennik takiego przyrodniczego ujęcia stosunku ruchu mechanicznego do materii stara się wykazać przy pomocy odpowiedniej argumentacji filozoficznej, że materia może zawdzięczać swój charakter kinetyczny nie sobie samej, ale jestestwu będącemu Bogiem, n i e p o tr z ebuje już odwoływać się do arystotelesowskiej def in i j i ruch u, pomyślanej w swej zasadniczej treści w oparciu o teorię możności i aktu. Wystarczy mu bardzo ramowe potraktowanie ze stanowiska filozofii przyrody ruchu mechanicznego, jego ujęcie jako bezwzględnej przypadłości modalnej bytów, które występują w naturze. Zadowoli się więc częściową tylko ontologizacją osnowy pojęcia ruchu znanego empirycznie. Resztę uwzględni w ramach definicji dejktycznej lub ostensywnej ${ }^{89}$ twierdząc, że ruchem mechanicznym jest na przykład to oglądane przez nas aktualnie konkretne zjawisko ruchu lokalnego i każde inne zjawisko, które nie daje się od niego odróżnić. Jak zobaczymy, te cząstkowe zabiegi definicyjne wystarczają, by można było podjąć się próby ostatecznego wytłumaczenia faktu ruchu mechanicznego i by można było dojść w ramach tej próby do przeświadczenia o istnieniu Boga.

$\mathrm{Na}$ szczególną uwagę zasługują filozoficzne implikacje arystotelesowskiej definicji każdego realnego ruchu w znaczeniu ścisłym, stanowiące kontynuację zastosowania do tego ruchu teorii aktu i możności. Nie wiążą się one $\mathrm{z}$ jakimś określonym przyrodniczym obrazem świata. Niemniej jednak są „zakotwiczone” w świecie rzeczywistym, gdyż pojęcia aktu i możności mają charakter realistyczny. Implikacje te należą w części do typu de duk c y jne g o, a w części - i to w części najbardziej decydującej - do typu redukc y jne go.

Jedna z nich wynika z k oniecznością logic zną z arystotelesowskiej definicji. Jest to twierdzenie, że wszystko, cu się porusza, jest jako takie w możności. Wszystkie inne implikacje, jakie można wyprowadzić dedukcyjnie z podanej definicji, są już tylko szeroko rozu-

${ }^{89}$ Zab. o tym typie definicji: Janina Kotarbińska, Tak zwana definicja dejktyczna, w: Fragmenty filozoficzne, seria druga - Księga pamiątkowa ku uczczeniu czterdziestolecia pracy nauczycielskiej w Uniwersytecie Warszawskim Profesora Tadeusza Kotarbińsktiego, Warszawa 1959, 44-74; C z ė̇ow s ki, Filozofia na rozdrożu..., 29-40. 
mianymi wnioskami, ustalonymi w następstwie rozwiązania w oparciu o ontologiczną zasadę racji dostatecznej zagadnienia wzajemnego stosunku zachodzącego między tym, co znajduje się w akcie i co jest w możności. Do tych implikacji należą w pierwszym rzucie dwa twierdzenia: a) wszystko, co porusza inny byt, o ile stanowi czynnik poruszający, jest $\mathrm{w}$ akcie, i b) to samo i pod tym samym względem nie znajduje się równocześnie w akcie i w możności. W oparciu o te twierdzenia, wzięte razem z podanym wyżej wnioskiem koniecznie wynikającym z arystotelesowskiej definicji ruchu ściśle rozumianego, jest się logicznie zmuszonym do wprowadzenia zasady ruchu. Jej sens przedstawia się następująco w świetle teorii aktu i możności: Wszystko, co przechodzi z możności do aktu, przechodzi doń pod wpływem tego, co już jest w akcie. Jeżeli teraz odwołamy się do ontologicznej zasady dostatecznej racji, powiemy w trakcie rozumowania redukcyjnego, że ostateczne, pełne wytłumaczenie jakiegokolwiek przejścia z możności do aktu może nam dać tylko byt, który jest czystym aktem, gdyż tylko taki byt, wolny od wszelkiej potencjalności, nie wskazuje poza siebie na jakiś różny od niego czynnik aktualizujący. W ten sposób teza o istnieniu Boga, pojętego jako czysty akt, stanowi ostateczną implikację filozoficzną arystotelesowskiej definicji każdego realnego ruchu ściśle rozumianego.

Na podkreślenie zasługuje okoliczność, że Boga, ujętego w podany sposób, nie musi się pojmować jako be zpośredniego sprawcę ruchu w świecie. Czysty Akt, który ze Swej natury istnieje nie na przedłużeniu motorów zależnych (będących aktami z przymieszką możności), lecz jako coś w stosunku do nich transcendentnego, może p ośredn i o warunkować ruch w świecie, o ile jest stwórcą materii obdarzonej uzdolnieniem do ruchu. W ten sposób okazuje się, że nie można zarzucić czysto filozoficznej argumentacji kinetycznej, iż zakłada ona z koniecznością logiczną coś, co jest niezgodne z poglądami fizyki współczesnej. Obecnie już nie mogę powtórzyć tego, co napisałem w studium Zagadnienie punktu wyjścia kinetycznej argumentacji $z a$ istnieniem Boga ${ }^{90}$, że zastosowanie do ruchu lokalnego czy do innych form ruchu ściśle rozumianego pojęć aktu i możności doprowadziło w swych konsekwencjach do powstania pseudoproblemu istnienia bezpośredniego pozaświatowego sprawcy ruchu, który to pseudoproblem dotąd będzie się odradzał w takiej czy innej postaci, dokąd zachowa się jego źródło - arystotelesowską definicję ruchu ściśle rozumianego.

Wyodrębnione przez nas $\mathrm{z}$ tej definicji implikacje filozoficzne mają częściowo inną treść niż ta, jaką uwzględniał Tomasz z Akwinu. Tłumaczy się to konsekwentnym zastosowaniem do całej

90 S. 94. Zob. też w: Z zagadnień..., s. 71, przyp. 136. 
kinetycznej argumentacji teorii aktu i możności, które pociągnęło za sobą wprowadzenie ontologicznej zasady racji dostatecznej. Dzięki posłużeniu się tą zasadą odpadła konieczność odwoływania się do tezy, że w serii bytów poruszających inne i poruszanych nie można posuwać się w nieskończoność. A wraz ze wskazaną tezą odpadło również powiązanie argumentacji kinetycznej z dawno zarzuconym przyrodniczym obrazem świata, jaki za Arystotelesem przyjmował Akwinata.

W przedstawionych wyżej filozoficznych implikacjach arystotelesowskiej definicji ruchu w znaczeniu ścisłym zasługuje jeszcze na uwagę okoliczność, że aspekt kinetyczny materii został rozpatrzony wyłą c znie od strony przechodzenia z możności do aktu. Ale jeżeli w ten sposób ujmuje się ów aspekt, można również tak samo potraktować ruch w sensie metaforycznym, jakim są czynności naszego umysłu i woli, które dokonują się całe naraz. Wprawdzie nie stosuje się do nich definicja ruchu ściśle rozumianego, gdyż nie stanowią ciągu sukcesywnych, częśsiowych realizacji bytowych, niemniej jednak w ich przypadku jednostka ludzka staje się z poznającej lub chcącej in potentia poznającą czy chcącą in actu. Dzięki poszerzeniu o wymienione czynności pojęcia ruchu stajemy przed możliwością skonstruowania argumentacji kinetycznej, dla której bazę wyjściową będzie stanowiła ws zelk a z mi a na, zarówno zmiana realizowana sukcesywnie, jak i zmiana momentalna. Będzie to druga postać argumentacji ex motu, w której nie potrzebujemy odwoływać się do poglądów fizyki współczesnej na temat stosunku ruchu do materii. Ponieważ to odwoływanie się jest jednak konieczne w przypadku argumentacji kinetycznej, w której nie uwzględnia się arystotelesowskiej definicji ruchu ściśle rozumianego, dlatego $\mathrm{w}$ następnym paragrafie przejdę do ustalenia tego, co fizyka współczesna sugeruje w przedmiocie stosunku ruchu do materii.

§ 2. Zagadnienie relacji między materią i ruchem w ujęciu fizyki współczesnej

1. Zanim rozpatrzę, jak przedstawia się stosunek ruchu do materii w świetle fizyki współczesnej, chciałbym wpierw podkreślić, co stało się już widoczne z przeprowadzonych wyżej analiz, że ,zakotwiczenie" argumentacji kinetycznej w rzeczywistości nie musi dokonywać się na jeden sposób. Wszystko zależy od wybranego przez nas rodzaju adekwatnego opracowania filozoficznego ruchu, znanego nam $\mathrm{z}$ poznania potocznego i fizykalnego.

Gdy ruch określimy ze strony filozofii przyrody jako akt bytu ist- 
niejącego w możności jako możności, wówczas, posługując się ontologiczną zasadą racji dostatecznej, nie potrzebujemy wchodzić w kwestię, czy ruch należy do potraktowanej empiriologicznie istoty materii, by dojśćdo przeświadczenia o istnieniu Boga. Nasze rozumowanie filozoficzne nie będzie wiązało się ze współczesnym, ani z żadnym innym przyrodniczym obrazem świata. Tak jest również i wtedy, gdy w bazie empirycznej argumentacji kinetycznej wychodzimy poza ruch ściśle rozumiany w kierunku jakiejkolwiek zmiany.

Kiedy jednak nie charakteryzujemy ruchu przy pomocy pojęć aktu i możności, lecz traktujemy go w płaszczyźnie kosmologii filozoficznej bardzo ramowo jako bezwzględną przypadłość modalną bytów z obrębu przyrody, wówczas w trakcie próby ostatecznego wytlumaczenia jego genezy nie możemy pominąć pytania, w jakim stosun$\mathrm{ku}$ pozostaje on do materii: czy jest jej narzucony z zewnątrz, czy też stale do niej przynależy i posiada w niej swą bliższą przyczynę sprawczą lub raczej zasadę. Bez rozstrzygnięcia tego zagadnienia nie wiedzielibyśmy, jakie dokładnie dane mamy ostatecznie tłumaczyć w ich genezie. Jest bowiem tak, że przy wskazanym dopiero co, bardzo ramowym określeniu filozoficznym ruchu nie wychodzimy $\mathrm{w}$ zasadzie poza problem, jaki stawia sobie fizyk w przedmiocie relacji ruchu mechanicznego do materii, lecz ujmujemy tylko ten problem z pomocą pojęć ontologicznym w znaczeniu szerszym, a nie pojęć empiriologicznych. Stąd też przy tej wersji argumentacji kinetycznej nie możemy uniknąć jej zależności od poglądów współczesnej fizyki.

Tę zależność nazywam zależnością p o śr e d n i ą. Czynię tak dlatego, gdyż w przypadku omawianego typu argumentacji kinetycznej nie chodzi o wprowadzenie w obręb filozofii Boga obcej dla niej enklawy z zakresu poznania fizykalnego. Ustalenia dokonane w płaszczyźnie fizyki są tu przetransponowane na ujęcie $\mathrm{z}$ dziedziny szeroko rozumianego poznania ontologicznego. To ujęcie stanowi czynnik pośredniczący w recepcji ustaleń fizyki. Dzięki temu czynnikowi pośredniczącemu może dokonać się organiczne zasymilowanie przez filozofię Boga ${ }^{91} \mathrm{w}$ jednej $\mathrm{z}$ dopuszczalnych postaci argumentacji kinetycznej tego, co zostało ustalone ze strony fizyki w przedmiocie relacji ruchu do materii.

2. Do tego ustalenia doszło najpierw w odniesieniu do molekul. Miało to miejsce w ramach molekularno-kinetycznej teori materii, według której molekuły są obdarzone pewną energią kinetyczną, zależną od temperatury bezwzględnej środowiska, i dlatego znaj-

91 A przedtem przez filozofię przyrody. 
dują się w stałym ruchu. Teoria ta znalazła najpełniejsze opracowanie dla gazów. Ale z jej strony również zjawiska cieplne zostały potraktowane jako przejaw energii kinetycznej ruchu molekuł. Później zaczęła się rozwijać kinetyczna teoria ciał stałych (krystalicznych), której intensywny rozwój liczy niewiele ponad pół wieku. Najmniej została dotąd opracowana kinetyczna teoria cieczy, a to z racji trudności, jakie przedstawia dla systematycznego ujęcia przejściowa pozycja cieczy między gazem i ciałami stałymi ${ }^{\mathbf{2}}$.

Chociaż molekularno-kinetyczna teoria materii powstała na gruncie fizyki klasycznej i wywodzi się z inspiracji mechanistycznych, to jednak jej zasadnicza myśl o kinety c zny m charakterze materi w zakresie jej molekuł, wyrażana obecnie z pozycji mechaniki relatywistycznej i fizyki kwantowej, znalazła daleko idące potwierdzenie częściowe. Jest to ,oddolne”, pośrednie potwierdzenie e m p i r y c z n e i, ,odgórne” potwierdzenie t e o r e t y c z n e.

Do ,oddolnego”, pośredniego potwierdzenia empirycznego doprowadziły w odniesieniu do cieczy i gazów doświadczenia, jakie zostały dokonane nad ruchami Browna i nad uzależnionymi od nich procesami, jak zmiennośc koncentracji emuls ji i zjawisko Tyndalla (zjawisko opalescencji) ${ }^{93}$. „Odgórne”, częściowe potwierdzenie teoretyczne molekularno-kinetycznej teorii materii możemy uzyskać odwołując się do dalszego whiosku trze ciej zasady termodynamiki, którą pojmuję za Białobrzeskim ${ }^{94}$, jako twierdzenie Nernsta-Plancka. Chodzi tu o wniosek, że osiagnięcie temperatury zera absolutnego nie jest moż 1 i w e, mimo że z pomocą zewnętrznego pola magnetycznego spinów układu termicznie izolowanego uzyskano temperaturę rzędu $0,001^{\circ} \mathrm{K}$, a nawet temperaturę bliską $10^{-6} \mathrm{~K}{ }^{95}$. Wskazany wniosek (razem z twierdzeniem Nernsta-Plancka) stosuje się w obrębie termodynamiki fenomenologicznej do samych substancji skondensowanych, a więc do ciał stałych i ciekłych. Żeby można go rozciągnąć na gazy doskonałe, a zwłaszcza

92 Zab. Sz. Szczeniowski, Fizyka doświadczalna, cz. II, 188-286.

93 Por. Z zagadnień..., s. 158. - Szczeniowski pisze (dz. cyt. cz. II, 211), że „, be z pośrednim dowodem słuszności założeń teorii kinetycznej jest istnienie tzw. ruchów Browna”. (Podkreślenie moje). Jeżeli jednak ruchy Browna stanowią odzwierciedlenie ruchu cieplnego molekuł, to odwoływanie się do ruchów Browna może stanowić tylko pośredni dowód kinetycznego charakteru molekuł cieczy i gazów.

94 Termodynamika (wyd. z r. 1955), 174-177.

95 Zob. F. R e if, Fizyka statystyczna [Statistical Physics], tłum. z ang. Tomir Coghen i Jenzy Łaskiewricz, Warszawa 1971, 222-223. Por. w Termodynamice Białobrzeskiego (s. 117) dawniejsze osiągnięcia uzyskane przy pomocy efektu magneto-kalorycznego. Por. jeszcze w tomie I niniejszej pracy o temperaturach uzyskanych w Lejdzie $1950 \mathrm{r}$. w trakcie doświadiczeń przeprowadzonych przez Becquerela prizy współudziale Gortera. 
na gazy rzeczywiste, trzeba dokonać pewnych modyfikacji w twierdzeniu Nernsta-Plancka przyjmując z pozycji mechaniki kwantowej, że w pobliżu zera absolutnego nie sprawdza się równanie Clapeyrona dla stanu gazów doskonałych i że ciepło właściwe $\mathrm{C}_{\mathrm{v}}$ wykazuje $\mathrm{w}$ ich przypadku zależność od temperatury, tak że dochodzi do tzw. zwyrodnienia gazów doskonałych ${ }^{96}$. Jeżeli więc zero absolutne jest nieosiągalne, to ponieważ energia kinetyczna molekuł jest proporcjonalna do temperatury bezwzględnej środowiska, z twierdzenia Nernsta-Plancka wynika, że nie ma molekuł pozbawionych całkowicie energii kinetycznej, a w konsekwencji i ruchu. Jest to cz ęś c i o w e potwierdzenie tego dalszego twierdzenia teorii molekularno-kinetycznej materii, gdyż w ramach termodynamiki fenomenologicznej znajduje ono zastosowanie tylko do substancji skonsensowanych, a przy uwzględnieniu mechaniki kwantowej zakres jego ważności również jest ograniczony, jeżeli jest tak, jak utrzymuje Szczeniowski ${ }^{97}$, że „najwłaściwiej byłoby uważać za trzecią zasadę termodynamiki nie dające się wyprowadzić z pierwszej i drugiej zasady ogólne prawidłowości dotyczące zmian entropii w gazach i w układach skonsensowanych w temperaturach bliskich zera bezwzględnego oraz zmian entropii zachodzących przy mieszaniu izotopów".

Obraz kinetycznego charakteru materii został z upływem badań uzupełniony po uwzględnieniu nowych zjawisk i prawidłowości, których nie znano w teorii molekularno-kinetycznej. Chodzi tu o takie przejawy autokinezji w znaczeniu szerszym, jak ruch obrotowy drobiny jako całości, oscylacja atomów, ruch precesyjny elektronów, drgania sieci krystalicznej itd. Szczególnie ważne dla kinetycznej koncepcji materii sa twierdzenia fizykalne dotyczące spinu cząstek. Jeszcze bardziej doniosłe implikacje posiada Einsteinowska formuła ukazująca związek między masą i energią i określająca ich swoistą, ,równoważność" ${ }_{98} \mathrm{E}=\mathrm{mc}^{2}$. Formuła ta przyporządkowuje masie bezwładnej jakąkolwiek postać energii, a więc także i energii kinetycznej. Tym samym ukazuje ona ścisły związek

96 Zob.: Białobrzeski, dz. cyt., 176; Szczeniowski, dz. cyt., cz. II, 164. - Gdy idzie o Szczeniowskiego, to on sądzi, że założenie Planoka, iż entropia układu skondensowanego jest w $0^{\circ} \mathrm{K}$ równa zeru, stanowi inne sformułowanie twierdzenia Nernsta. Podzielając ten pogląd może jednak Szczeniowski podjąć wszystkie wnioski, jakie wynikają z twierdzenia Nernsta. Por. o stosunku twierdzenia Plancka do twierdzenia Nernsta u Kazimierza Gumińskiego w jego Termodynamice (Warszawa $1972^{2}$ ) s. $289-292$.

97 Dz. cyt., cz. II, 164.

98 Podane zastrzeżenia tym się tłumaczą, że równoważność jest stosunkiem logicznym zachodzącym między zdaniami, a nie między przedmiotami, o których mówi fizyka. Jeżeli więc w naszym przypadku chcielibyśmy wyrazić się z całą ścisłością, powinni byśmy mówić jedynie o równoważności zdań odnoszących się do masy bezwładnej i energii. Możemy jednak uważać twierdzenie o ,równoważności” masy bezwładnej i energii na skrótorwe wyrażenie twiendzenia o równoważności zdań o tych dwu rzeczywistościach fizycznych. 
między masą bezwładną i ruchem mechanicznym. Korelacja ta posiada zarówno odgórne potwierdzenie teoretyczne, jak i oddolne potwierdzenia obserwacyjne. Przeciwnicy relatywistycznej kinematyki usiłowali w przeszłości przeciwstawiać koncepcjom Einsteina wyniki doświadczeń D. C. Millera ${ }^{99}$ i W. Kaufmanna ${ }^{100}$. W obecnym etapie badań, mimo iż ciągle podejmowane są nowe próby modyfikacji teorii względności, to jednak w próbach tych nie kwestionuje się zasady podstawowych założeń wprowadzonych przez Einsteina i nie podważa związku między energią i masą wyrażonego $\mathrm{w}$ formule $\mathrm{E}=\mathrm{mc}^{2}$. Obszerny zbiór efektów relatywistycznych można przytaczać jako częściową konfirmację empiryczną szczególnej teorii względności oraz implikowanego przez nią twierdzenia o związku masy bezwładnej z ruchem fizycznym. Dane te wykazują tym samym dowolność tradycyjnych wyobrażeń o stosunku materii do ruchu oraz zasadniczą trudność utrzymania ich w kontekście fizyki współczesnej.

Po uwzględnieniu całości przytoczonej argumentacji możemy stwierdzić, że, w miarę posuwania się badań fizykalnych, stajemy wobec coraz liczniejszych „oddolnych” potwierdzeń empirycznych i „odgórnych” potwierdzeń teoretycznych twierdzenia, iż ruch mechaniczny — bezładny ruch cieplny molekul lub ich ruch obrotowy, czy występująca w nich oscylacja atomów i ruch precesyjny elektronów wokół osi molekuł, albo drganie sieci krystalicznej czy ruch wiązany z pojęciem spinu itd. przysługuje materii stale, choć zawsze w odniesieniu do pewnych układów odniesienia. Inspirując się epistomologicznymi rozróżnieniami Maritaina możemy treść tego twierdzenia

99 Jeszcze około r. 1930 utrzymywano (np. Białobrzeski, Teoria względnoś$c i$, t. XXII Wydawnictw Koła Matematyczno-Fizycznego Słuchaczów Uniwersytetu Warszawskiego, Warszawa 1930,61), oczywiście z zachowaniem należnej rezerwy, że trudność dla szczególnej teorii względności stanowi to, iż fizyk amerykański Dayton Cl. Miller otrzymał pozytywny wynik dla doświadczenia Michelsona-Morleya, posługując się interferometrem na górze Wilsona. Późniejsze badania dowiodły jednak, że ten wynik pozytywny był uwarunkowany przez zakłócenia cieplne, których Miller nie wyłączył. Zob. „Naturwissenschaften”, (1929) 923, (1931) 784, 934. Przeciw twierdzeniu Millera, że „wiatr eteru” ujawnia' się w dalszych rejonach od Ziemi, która w najbliższym swym atoczeniu ma unosić ze sobą eter, przemawia szczególnie okoliczność, że doświadczenie Michelsona-Morleya, powtórzone przez Augusta Piccarda w balonie na wysokości znacznie wyższej od góry Wilsına, dało wynik całkowicie negatywny.

100 Chodzi tu o doświadczenia Waltera Kaufmanna z lat 1902-1906 i o doświadczenia Bücherera $z$ lat 1908-1909. Pierwszy $z$ tych badaczy promienie $\beta$, emitowane przez ziarno fluorku radu, odchylał równocześnie $w$ dwu kierunkach prostapadłych przez pole magnetyczne i pole elektryczne. Jego pomiary nie były jednakże dość precyzy.je. (Zob.: Stanisław L oria, Względność i grawitacja -- Teoria Einsteina, Lwów 1922², 63-64; Paul Langevin, Le principe de relativitó, Paris 1922, 4142). Większą zgodność z wzorem Lorentza i Einsteina, jaki podaję nieco dalej, osiagnął Bücherer, który tak kierował polem magnetyoznym i polem elektrycznym, że ich działania się kompensowały. 
wyrazić w słowach, że ruch mechaniczny należy, z podanym ograniczeniem, do empiriologicznie ujętej istoty materii.

Jaki jest stopień uzasadnienia wskazanego twierdzenia?

Zaczynając od jego ,oddolnych” uzasadnień zauważmy, że t e s t y e mpiryczne, jakie dlań zebrano ${ }^{101}$, nie stanowią jeszcze jegokonkluzywnej weryfikacji, nie są pełnym dow o d e m. Tak jest dlatego, gdyż te testy wykorzystuje się w ramach rozumowania, które nie jest rozumowaniem niezawodnym. Nie jest to bowiem rozumowanie dedukcyjne, lecz redukcyjne, mianowicie tłumaczenie, a takie rozumowanie, w którego przypadku z prawdziwości następstwa nie wynika prawdziwość racji, prowadzi jedynie do konfirmacji o określonym stopniu prawdopodobieństwa, jeżeli nie są dostępne dodatkowe zabiegi mogące dać nam pewność.

W drodze „odgórnych" uzasadnień teoretycznych nie dochodzimy równieź wonkluzji doweryfikacji twierdzenia o kinetycznym charakterze materii. Gdy bowiem odwołujemy się do trzeciej zasady termodynamiki, pojętej w podany wyżej sposób, nie wychodzimy poza konfirmację o określonym

101 Chciałbym tu ustosunkawać się do wypowiedzi St. Kamińskiego, przedstawionej na wymienionym poprzednio sympozjum filozoficznym, które adbyło się w arcybiskupiej rezydencji Kard. Wojtyly.

Kamiński twierdził, że nie można utrzymywać, iż „fakty i teoria to są rzeczy różne”. A nie można utrzymywać dlatego, gdyż „fakty naukowe są wyrażone w terminologii teorii. Nie może być fakt naukowy opisany inaczej jak w języku właściwym dla całej teorii. Pozornie adróżnia się tylko język faktów od języka teorii. Każdy metodolog nauk przyrodniczych dobrze wie, jak mocno wiążą się fakty i teoria. Ma to miejsce, gdy chodzi o obalalność teorii. Zdanie obserwacyjne może abalić teorię. Ale mogę odrzucić teorię a zachować to zdanie obserwacyjne. Oddzielenie przeto języka teorii i faktów jest wcale nie do przyjęcia". (Zob. w sprawozdaniu E. Moraw ca Sympozjum filozoficzne poświęcone analizie punktu wyjścia kinetycznego $i$ teleologicznego argumentu na istnienie Boga, 240).

Jeżeli Morawiec dokładnie przytoczył wypowiedź Kamińskiego, to trzeba zauważyć, że jest ona nie dość logicznie spójna w swej treści. Najpierw Kamiński twiendził, że fakt naukowy nie daje się opisać inaczej ,jak w języku właściwym dla całej teorii", tak że znika różnica między językiem faktów a językiem teorii. Później jednak powiedział w sposób pośredni coś wręcz przeciwnego, gdy wyraził się, że można odrzucić teorię i mimo to zaćhować [występujące u jej podstaw] zdanie obserwacyjne. I tę zmianę poglądów zakończył nieoczekiwanie zdaniem: „Oddzielenie przeto języka teorili i faktów jest wcale nie do przyjęcia".

Pomijając tę niejednolitość poglądów, występującą może w samej tylko niezręcznie dokonanej rekonstrukcji prelekcji, chciałbym podkreślić, iż z Kaminskim łączy mnie przekonanie, że przy żadnym fakcie nie chodzi o czystą i prostą transkrypcję rzeczywistości. Nie sądzę jednakże, żeby w przypadku faktów znikały dane z obrębu rzeczywistości, mimo że nadajemy tym danym określoną interpretację i tłumaczymy je tak czy inaczej. Te dane posiadają wzaględną autonomię w stosunku do wszystkich teorii i dlatego język faktów wyodrębnia się przynajmniej do pewnego stopnia od języka każdej teonii.

Krytycznym rozumieniem faktów w ogólności, a faktów naukowych w szczególności, zająłem się w pracach: Zagadnienie metody filozofii przyrody we wspótczesnej neoscholastyce, „Roczniki Fillozoficzne”, 9 (1961, z. 3) 6-9; Z teorii i metodologii filozofii przyrody, 124-126, 132-136. 
stopniu prawdopodobieństwa. Posługujemy się tu wprawdzie dedukcją, ale choć wśród jej treści wyjściowych ma miejsce kontakt $\mathbf{z}$ danymi doświadczenia (Nernst uwzględniał doświadczenia dotyczące własności termicznych ciał $\mathrm{w}$ pobliżu $0^{\circ} \mathrm{K}$ ), to jednak twierdzenie Nernsta jest założeniem teoretycznym i takimże założeniem jest uzupełniające je twierdzenie Plancka. Dodać jeszcze trzeba, że - jak o tym była już mowa teoria molekularno-kinetyczna materii znajduje częściowe tylko potwierdzenie o wskazanym charakterze prawdopodobieństwościowym nie tylko na gruncie termodynamiki fenomenologicznej, ale również przy uwzględnieniu mechaniki kwantowej, odnosząc się $\mathrm{z}$ kolei do formuły $\mathrm{E}=\mathrm{mc}^{2}$, która zawiera implicite myśl o związaniu w materii masy bezwładnej z ruchem mechanicznym - nie uzyskujemy również konkluzywnej weryfikacji dla twierdzenia o kinetycznym charakterze materii. Ten stan rzeczy tłumaczy się tym, że formuła ta w swoich najdalej idących potwierdzeniach, jakimi są niektóre jego potwierdzenia ,oddolne” (zjawisko tzw. dematerializacji w skali mikrokosmicznej i makrokosmicznej, a także zjawisko tzw. materializacji), zbliża się tylko wydatnie do twierdzenia prawdziwego w sensie klasycznym. Zbliża się do takiego twierdzenia, nie stając się nim jeszcze definitywnie, gdyż w przypadku zjawisk tzw. dematerializacji i materializacji chodzi o doświadczenie szerzej rozumiane, w którym dane empiryczne wiążą się ściśle z interpretacjami teoretycznymi.

Jednakowoż stopień prawdopodobieństwa twierdzenia o przynależności (z wiadomym ograniczeniem) ruchu mechanicznego do empiriologicznie rozumianej istoty materii jest $d u$ ż y. Jest duży ze względu na wielość danych doświadczenia, które tłumaczą się kinetycznym charakterem materii. Stopień prawdopodobieństwa jest także duży z racji naturalności tego tłumaczenia. Ta naturalność jest niejednokrotnie tak uderzająca, że fizyk potrafi jak widzieliśmy - napisać, że „bezpośrednim dowodem słuszności założeń teorii kinetycznej jest istnienie tzw. ruchów Browna". O dużym prawdopodobieństwie ocenianego twierdzenia świadczy również okoliczność, że można je wyprowadzić ze szczególnej teorii względności, która posiada własne testy empiryczne. Chociaż więc nie możemy utrzymywać w płaszczyźnie współczesnej fizyki, żeby kinetyczny charakter materii został $\mathrm{w}$ pełni udowodniony, to jednak jego prawdopodobieństwo jest tak wielkie, że nie można go negować bez rezygnacji z czołowych obecnie teorii fizykalnych ${ }^{102}$.

3. Chcąc poprawnie ująć sens fizykalnego obrazu kinetycznego ma-

${ }_{102} \mathrm{~W}$ tym sensie należy stonować to, co w rozprawie Zagadnienie punktu wyjscia kinetycznej argumentacji $z a$ istnieniem Boga (s. 97, 101, 104-105) i w pracy: $\mathrm{Z}$ zagadnień filozoficznego poznania Boga (s. 72) pisałem o ujęciu stosunku ruchu do materii ze strony fizyki współczesnej.

6 - Analecta Cracoviensia 
terii, należy zwrócić uwagę na okoliczność, że w pojęciu ruchu mechanicznego mieści się pojęcie stosunku. Na tę komponentę treściową zwrócił już uwagę Jerzy Berkeley. „Aby pojąć ruch - pisał on - trzeba koniecznie przedstawić sobie co najmniej dwa ciała, których odległość, czyli położenie wzajemne jest zmienne. A więc, gdyby istniało tylko jedno ciało, to nie mogłoby się ono poruszać. Wydaje się to oczywiste wobec tego, że idea ruchu, jaką posiadam, musi zawierać w sobie stosunek" ${ }^{103}$. To trafne ujęcie Berkeleya należy tylko odłączyć od przygodnie związanego z nim stanowiska metafizycznego idealizmu subiektywnego w wersji immanentnej ${ }^{104}$, wyrażającego się w odniesieniu do ruchu $\mathrm{w}$ przekonaniu, że ruch, znany $\mathrm{z}$ doświadczenia, nie ma istnienia niezależnego od jego spostrzegania ${ }^{105}$. Pozostając na pozycjach realizmu metafizycznego i gnozjologicznego powiemy razem z Einsteinem ${ }^{106}$, że ruchowi samemu w sobie nie możemy przypisać żadnego sensu, bo istnieje tylko ruch względem danego ciała odniesienia.

$\mathrm{Z}$ tą właściwością ruchu wiążą się pewne ograniczenia kinetycznej koncepcji materii, których Dorda jakoś nie dostrzegł. Jego pozycja w stosunku do tej koncepcji opierała się na nieporozumieniu. Autor ten argumentował w ten sposób:

„Ruch lokalny nie należy do istoty materii. Gdyby należał, to nie

103 Traktat o zasadach poznania ludzkiego, tłum. Jana Leszczyńskiego, opracowane przez Tadeusza Czeżowskiego, Bolesława J. Gaweckiego i Czesława Znamierowskiego, wyd. z Trzema dialogami między Hylasem $i$ Filonousem przez „Bibliotekę Klasyków Filozofii", [bmw] 1956, 115, n. 112.

${ }_{104}$ Idę tu za terminologią A jdukiewicza (Zagadnienia $i$ kierunki filozofii, $126-127)$.

$105 \mathrm{Za}$ próbę współczesnego wyrażenia z pozycji realizmu spostrzeżenia, jakiego dokonał Berkeley, można uważać to, co J. W. Weissenhof mówił w pierwszym dniu wymienionego już sympozjum filozoficznego, które miało miejsce w arcybiskupiej rezydencji kard. Wojtyły. Weissenhof wysunął pogląd, że jeżeli przez materię będziemy w makrofizyce rozumieli „z pozycji teorii względności” punkt materialny, czyli ,jakieś małe ciało sztywne, jakiś szczególny przypadek materii”, ,to nie można powiedzieć, że ruch jest własnością tego punktu materialnego, gdyż punkt materialny sam przez się nie ma żadnych prędkości. On ma inną prędkość - jak się mówi w języku potocznym - względem ziemi, inną ma względem słońca, względem pociągu itp. Raczej - jak to coraz częściej się podkreśla i zwraca uwagę aby mówić o prędkości trzeba, aby były przynajmniej dwie cząstki. Wówczas jest prędkość bądź zbliżania się, bądź oddalania się. Każda z tych prędkości jest różna względem określonego układu odniesienia np. słońca, ziemi, pociągu. Sytuacja ta, zdaniem prof. Weissenhofa, wskazuje, co zresztą wielu fizyków przyjmuje, że każda cząstka materii brana z osobna nie ma właściwej sobie prędkości". Według Weissenhofa to by przeczyło tezie, która głosi, że ruch jest stałą własnością materii. (Zob. w sprawozdaniu E. M or a w c a Sympozjum filozoficzne poświęcone analizie punktu wyjścia kinetycznego $i$ teologicznego argumentu na istnienie Boga, 227-228).

W przytoczonej wypowiedzi można tylko podać w wątpliwość jej końcowy wniosek. Bo jeżeli przez materię będziemy rozumieli przynajmniej dwa ,punkty materialne" - a to jest niezbędne do sensownego wyrażenia kinetycznej teorii materii i nie wchodzi w żaden konflikt ze szczególną teorią względności — nie natkniemy się na trudność, z jaką spotkał się Weissenhof.

106 Uber die spezielle und die allgemeine Relativitätstheorie, § 16, s. 37. 
byłby możliwy spoczynek, który tu określamy jako prędkość zerową utrzymującą się przez czas skończony. Łatwo widać na przypadku rzutu pionowego, jak można zrealizować prędkość zerową przez czas skończony: wystarczy $\mathrm{w}$ chwili osiągnięcia najwyższego punktu drogi, a więc prędkości zerowej, podstawić pod ciało deskę. Zdajemy sobie dobrze sprawę, że na takie dictum wysunie się moc zastrzeżeń czerpanych $\mathrm{z}$ ruchu drobinowego itp. Dlatego podsunęliśmy tylko ideę dowodu, który przeprowadzimy na rzucie pionowym elektronu pomiędzy dwiema okładzinami kondensatora pozbawionego ładunku przez czas trwania rzutu pionowego $\mathrm{w}$ polu grawitacyjnym. W chwili osiągnięcia przez elektron prędkości zerowej włączamy pole elektrostatyczne przeciwnie skierowane i równe co do natężenia natężeniu pola grawitacyjnego. Przeciw temu doświadczeniu można by wysunąć zarzut, że operuje się pojęciem ściśle określonego punktu i chwili, co stoi w sprzeczności z nieoznaczonościami Heisenberga. Atoli ten zarzut likwiduje prosta uwaga, że prawa mechaniki kwantowej nie pozwalają wprawdzie na twierdzenie, iż w każdym wypadku w tych samych warunkach doświadczenia otrzymamy ten sam wynik, z drugiej jednak strony pozwalają obliczyć prawdopodobieństwo takiego wyniku, a więc nie tylko możliwość, lecz zarazem, na ile wypadków powtórzenia doświadczenia ściśle oznaczony wynik dojdzie do skutku.

Drugim argumentem za brakiem przynależności ruchu lokalnego do istoty materii jest względność ruchu i spoczynku. Zdajemy sobie sprawę, co fizycznie oznacza twierdzenie, że ruch lokalny należy do istoty materii. Względność ruchu oznacza, że podstawowe prawa przyrody mają ten sam wyraz matematyczny niezależnie od tego, w której cząstce materii mającej ruch względny z jakąkolwiek inną cząstką założymy układ współrzędnych. Wobec tego przyjąwszy w dowolnej cząstce układ odniesienia, powiemy, że druga cząstka spoczywa, gdy jej odległość od początku układu jest stała, zaś porusza się, gdy odległość jest zmienna. Otóż kto twierdzi, że ruch lokalny należy do istoty materii, tym samym twier$\mathrm{dzi}$, że do istoty materii należy, aby nie istniała $\mathrm{w}$ świecie ani jedna para cząstek, zachowująca przez czas skończony odległość niezmienną. Nad niedorzecznością tego twierdzenia nie trzeba się długo zastanawiać. Wystarczy powołać się na wiązkę fotonów, w której dzięki wspólnej prędkości światła odległości pomiędzy poszczególnymi fotonami pozostają przez dowolny czas skończony stałymi" ${ }^{107}$.

Przytoczone wywody nie mogą nas przekonać. Jeżeli w idei ruchu mieści się koniecznie pojęcie stosunku, to przy tak rozumianym ruchu musi byćmiejsce na

107 Błędy w krytyce dowodu kinetycznego teodycei, 521-522. 
względny spoczynek przezczas skończony, bo to, co zmienia swą odległość w stosunku do jednego układu odniesienia, może jej nie zmieniać w relacji do innego układu. Stąd też, gdy opowiadamy się za kinetycznym charakterem materii, musimy go pojmować w ten sposób, by nie wykluczać możliwości względnego spoczynku. Należycie rozumiana teza o przynależności ruchu lokalnego do istoty materii nie zawiera w sobie niedorzeczności, jakiej dopatrywał się Dorda.

Możemy posunąc się jeszcze dalej twierdząc, że gdy uważa się kinetyczną koncepcję materii za wysoce prawdopodobną, za bardzo bliską prawdy, jest możliwe przy pośrednim wyzyskaniu tej koncepcji skonstruowanie pewnej formy argumentacji za istnieniem Boga ex motu. Za taką możliwością opowie się tym bardziej ten, kto, jak Różycki, przypisuje bez żadnych zastrzeżeń kinetycznej koncepcji materii wartość prawdy. Różycki zauważył: „Cały dowód bynajmniej nie zakłada, że ruch nie należy do natury ciał materialnych. Wszak św. Tomasz zna doskonale motus locales, qui sunt a natura, tzn. wynikają koniecznie z natury ciał. W jego wyobrażeniach fizycznych spadanie ciał ciężkich jest takim właśnie motus naturalis. Dowód św. Tomasza zachowuje zatem swoją ważność również wobec najnowszej fizyki, uważającej ruch za nieodłącznie związany z naturą materii. Sytuacja metafizyczna, jaką nam ten dowód odsłania, wygląda następująco: przyrodnik, a nawet i filozof, może na podstawie obserwacji i rozumowania dojść do wniosku, że ruch właściwy należy do struktury materii; metafizyk zaś, zastanawiający się nad ostateczną przyczyną wszystkiego, przy pomocy niniejszego dowodu dochodzi do wniosku, że nie sobie samej, ale Bogu zawdzięcza materia to, że ruch należy do jej struktury" ${ }^{108}$.

Spróbujmy rozwinąć tę ostatnią myśl Różyckiego, biorąc za punkt wyjścia nie tylko ruch mechaniczny, lecz również zmianę energii czv spinu.

Dla fizyka ruch w takiej czy innej postaci należy do ostatecznych danych. Jego genezą bytową się nie zajmuje, gdyż w swych badaniach nie uwzględnia aspektu bytowego rzeczywistości materialnej oraz przyczyn sprawczych w rozumieniu filozoficznym. To, na co zwraca uwagę fizyk w już istniejącym ruchu, są to zmiany w nich zachodzące, które pozwalają na wprowadzenie pojęcia siły. Zagadnienie genezy bytowej ruchu może podjąć dopiero filozof przyrody i filozof Boga, gdyż pozwala mu na to uwzględniana przezeń perspektywa pojęciowa.

Gdy przyjmuje się za fizyką współczesną, że jest prawie pewne, iż ruch należy do empiriologicznie ujętej istoty materii, wówczas w płaszczyźnie kosmologii filozoficznej nasuwa się jako najbardziej naturalne

108 Dogmatyka, t. I, ks. II, n. 477. 
przypuszczenie, że ruch posiada w materii swą bezpośrednią przyczynę sprawczą czy zasadę. Pełniej wyrazimy to przypuszczenie w słowach, że na gruncie filozofii przyrody jest co najmniej bardzo prawdopodobne, iż ruch jest wyrazem własnej aktywności materii, która, idzie o bliższą przyczynę sprawczą czy zasadę procesów kinetycznych, znajduje się w swym całokształcie w ruchu per se, dzięki własnym siłom lub energiom, pojętym ontologicznie jako jej absolutne własności jakościowe.

To ujęcie filozoficzne, zakotwiczone tylko pośrednio w poglądach fizyki współczesnej, spotkało się z licznymi zastrzeżeniami Dordy, który dość nieoczekiwanie wypowiedział się niemal całkowicie z pozycji fizyka.

Dorda zarzucał mi, że błędnie przyjmuję, iż siła nadaje ciałom ruch, gdy tymczasem powoduje ona jedynie przyspieszenie lub opóźnienie już istniejącego ruchu. Zdaniem Dordy moja krytyka argumentacji kinetycznej „wygląda na anachronizm z 17 wieku”, gdyż zakłada ,że zostało udowodnione istnienie sił, jako realnych wielkości fizycznych”. „Dowód taki musi założyć - pisał mój oponent - dwie rzeczy: 1) że przestrzeń jest Euklidesowa, 2) że bezwładność ciał pokrywa się z treścią definicji, podanej przez Galileusza. Gdy z tymi dwoma założeniami przystąpimy do przyczynowego wytłumaczenia zjawiska ruchów niejednostajnych, staje się logiczną koniecznością wprowadzanie obok tak pojętej bezwładności drugiego aspektu materii: dynamizmu. Wyróżnimy wtedy masę bezwładną od masy ciężkiej. - Nie ma atoli dowodu na powyższe dwa założenia: a raczej, jeśli za dowód można by uważać większą ogólność i użyteczność schematu teoretycznego w ujmowaniu zjawisk, to należałoby je uznać za fałszywe. Przyjmując, że przestrzeń czterowymiarowa jest Riemannowska i że definicja Galileuszowska bezwładności jest za ciasna (zamiast ruchu jednostajnego po prostej wchodzi w teorii względności ruch po krzywej geodetycznej), Einstein okazał, że nie ma różnicy między masą bezwładną a masą ciężką, czyli nie ma siły grawitacyjnej jako niezależnej obok masy i przestrzeni charakterystyki materii. Usiłowania fizyki teoretycznej idac w kierunku eliminacji sił elektrycznych i magnetycznych, jak dokonana przez Einsteina eliminacja wyodrębnionej obok bezwładności i przestrzeni siły grawitacyjnej" ${ }^{109}$.

Nie można również - zdaniem Dordy - uważać energii za przyczynę sprawczą zaistnienia ruchu. Pojęcie energii jest pojęciem syntetycznym, w którym występują łącznie pojęcia masy i ruchu. To, że z tego „pojęcia syntetycznego zrobiła się realność, tłumaczy się dość trywialnie, a mianowicie, tautologią matematyczną różniczki pracy z różniczką energii

109 Art. cyt., 524. Por. jeszcze w tym samym artykule s. 517--521 oraz w art. Pewność czy ryzyko? 1005-1006. 
kinetycznej: $m\left(d^{2} x / d t^{2}\right) \cdot d x=d\left(m^{2} / 2\right)$, gdzie prędkość $v=d x / d t$. Jeśli więc do wytworzenia pojęcia energii zużytkowaliśmy pojęcie masy i ruchu, a potem genezy ruchu szukamy w energii, to tłumaczymy idem per idem, lub co najwyżej funkcyjnie, lecz nie przyczynowo. Tłumaczyć funkcyjnie oznacza mówić o tej samej rzeczy innymi matematycznymi wyrazami. Otóż wątpię, czy ruch powstaje ze sposobu mówienia o nim" ${ }^{110}$.

Dorda nie byłby zapewne wystąpił $\mathrm{z}$ tymi zarzutami, gdyby był zorientował się $\mathrm{w}$ typie epistemologicznym pojęć siły i energii, jakimi posłużyłem się chcąc wskazać dla ruchu jego bliższą przyczynę sprawczą czy zasadę. Użyte przeze mnie pojęcia odnoszą się do porządku ontologicznego w znaczeniu szerszym, tymczasem Dorda nie wyszedł w całej swej krytyce poza pojęcia relatywne do por z ą d k u empiriologicznego. Stąd też jego krytyka rozmija się z celem przezeń zamierzonym.

$\S 3$. Nowe formy argumentacji kinetycznej w świetle szczegółowej analizy epistemologicznej i metodologicznej

§ 3. 1. Argumentacja kinetyczna zależna od fizyki wspótczesnej

1. Przyjąwszy jako coś bardzo bliskiego prawdy, że cały wszechświat ciał porusza się dzięki własnym, immanentnym siłom i energiom, pojętym we wskazanej dopiero co interpretacji ontologicznej, musimy stwierdzić, że obecnie szukanie bezpośredniego, pozaświatowego sprawcy ruchu materii straciło swe dawne, zdawało się niewzruszone, uzasadnienie przedmiotowe. Możemy pytać się tylko o to, czy dla ostatecznego wytłumaczenia genezy ruchu materii jesteśmy zmuszeni przyjąć istnienie jakiegoś jednego pośredni e go motoru pozaświatowego, całkowicie nieruchomego, od którego byty materialne posiadałyby swe uzdolnienie do ruchu, i czy tak rozumiany pierwszy motor trzeba utożsamiać z Bogiem.

Chcąc przebyć efektywnie całą drogę badań narzucających się w tym przedmiocie, musimy uwzględnić aspekt przygodności wyodrębnionych przez nas sił i energii. Jeżeli bowiem te siły i energie są czymś przygodnym, to $\mathrm{w}$ takim razie, gdy idzie o przyczynę ich istnienia, wskazują one poza kosmos, i to niezależnie od tego, jak byłyby długie ich ciągi i jaką zależnością przyczynową byłyby powiązane. $\mathrm{Z}$ tej też racji nie mogą stanowić ostatecznego wytłumaczenia dla genezy bytowej stwierdzonego empirycznie ruchu. Ten ruch stanie się dla nas pod względem swego istnienia ostatecznie zrozumiały dopiero wtedy, gdy założy-

110 Pewność czy ryzyko?, 1.c. 
my istnienie bytu bezwzględnie koniecznego, bytu a se, Boga, z którego a k t u s twórczego wy wodziłyby się wraz z materią jej siły i energie, stanowiące tylko bliżsą rację tłumaczącą dla ruchu. Gdy więc chcemy dojść do przeświadczenia o istnieniu Boga wychodząc od aspektu kinetycznego materii, wziętego nie po linii definicji arystotelesowskiej, lecz tak, jak się go bierze w bardzo ramowej ontologizacji przy pośrednim wpływie fizyki współczesnej ${ }^{111}$, musimy w decydującej fazie rozumowania przejść na tory wywodów ex contingentia. Możemy jednak nadal wyodrębniać w pewnej mierze ten typ argumentacji kinetycznej ${ }^{112}$ od innych ,dróg” prowadzących do poznania istnienia Boga, gdyż stanowi on próbę ostatecznego wytłumaczenia genezy bytowej ruchu, którego nie bierzemy za punkt wyjścia pozostałych „dróg”.

Okazuje się zatem, że zagadnienie istnienia pierwszego motoru nieruchomego jest zagadnieniem, które narzucało się nie tylko na gruncie przyrodniczego obrazu świata, za jakim opowiedzieli się Arystoteles i Tomasz z Akwinu. Zagadnienie to pojawia się również przy odpowiednim wykorzystaniu filozoficznym współczesnego przyrodniczego obrazu świata, mimo że różni się on bardzo od tego, co przyjmowano w teorii geocentrycznych sfer Eudoxosa. Zagadnienie filozoficzne, o które nam chodzi, musimy jednak przy obecnych poglądach przyrodniczych inaczej formułować, niż formułowali je Stagiryta i Tomasz.

2. Według Dordy tak jednak nie jest. „Wystarczy założyć świat argumentował ten autor - jako układ choćby nieskończony mas, napisać dla nich równania różniczkowe ruchu, czyli równania sił wzajemnych między masami, i zapytać, kto nadał temu układowi prędkości początkowe, nieodzownie konieczne, by ruch był zdeterminowany. Ponieważ jest to warunek determinacji, od mas, ich pozycji początkowych i od sił wewnętrznych układu niezależny, wymaga więc on bezpośredniego sprawcy, tj. wymaga przyczyny spoza układu ciał wszechświata. - Można jeszcze zastanowić się nad dwiema postaciami stworzenia pierwszego ruchu: albo ruch rozpoczął się od prędkości zerowej, albo od różnej od zera. Przypuśćmy, że pierwszy ruch rozpoczął się od prędkości zerowej. Widzieliśmy, że aby po niej pojawiła się prędkość różna od zera, ciała i siły muszą być przy prędkości początkowej zerowej wyprowadzone z położenia i ze stanu równowagi. Normalnie stać się to nie może inaczej, jak przez ruch poprzedzający ową prędkość zerową: siły bowiem działają tylko w sensie reakcji na już obecny ruch jednostajny, przeciwdziałają wprowadzonej zmianie, dążą do stanów równowagi. Tu jednak

111 Por. o tym w $\S 1$, n. 4 i w $\S 2$, n. 1.

112 Pomijam w tej chwili inne dopuszczalne postaci tej argumentacji. 
przyjęliśmy założenie, że chwila ta jest absolutnym początkiem ruchu w świecie, nie poprzedzonego żadnym ruchem, który by był odpowiedzialny za wyprowadzenie sił ze stanu równowagi. Istnieje więc bezpośredni sprawca tego stanu sił. Albo więc stworzył on układ z prędkościami zerowymi, ale z siłami niezrównoważonymi, albo z siłami zrównoważonymi, ale z prędkościami początkowymi różnymi od zera. W pierwszym wypadku musiał na siłach sprawić to, co normalnie sprawia ruch, to znaczy: wyprowadzić je (cudownie, bo bez ruchu) ze stanu równowagi lub wprost stworzyć w stanie nierównowagi. W drugim wypadku dzieje się to znacznie prościej: siły są w równowadze (do czego z natury dążą), a stwarza się bezpośrednio ruch, czyli rozpoczyna się go od prędkości różnej od zera. Różnica między jednym i drugim sposobem stworzenia ruchu jest nieistotna, sprowadza się bowiem do pytania, czy stworzony pierwszy ruch miał w chwili początkowej prędkość zero, czy prędkość różną od zera. Przypominamy z rozważań Schrödingera, że prędkość zerowa w chwili pierwszej nie oznacza spoczynku, chyba że i w chwili następnej będzie zerem. Tym sposobem mechanika Newtona stawia nas w obliczu zagadnienia o bezpośrednią przyczynę zaistnienia ruchu, która w układzie obejmującym wszechświat, musiała zrealizować czwarty i od sił wewnętrznych niezależny warunek determinacji ruchu: prędkości początkowej" ${ }^{113}$.

Przytoczone rozumowanie nie jest wolne od pewnych uproszczeń. Zwrócił już na nie uwagę Aleksander Legatowicz. „Przy tego rodzaju rozumowaniu [jak rozumowanie Dordy] — pisze ten autor - pamiętać [...] należy, że [...] stanem początkowym może z powodzeniem być stan spoczynku, w którym wszystkie prędkości początkowe są równe zeru. Pomimo to układ przejdzie następnie w stan ruchu bez oddziaływania z jakimkolwiek układem zewnętrznym, jeżeli tylko istnieją siły oddziaływania pomiędzy ciałami wchodzącymi w skład układu. Ponadto na gruncie mechaniki Newtona znajomość stanu układu w określonej chwili czasu pozwala odtworzyć całą historię układu bez wprowadzania oddziaływania z jakimkolwiek układem zewnętrznym posuwając się dowolnie daleko w przeszłość" ${ }^{114}$.

3. Masi utrzymuje, że według nauk przyrodniczych kosmos materialny posiada w sobie moc do doskonałego spełniania wszystkich czynności naturalnych sobie właściwych, tak że nie potrzebuje jakiejś siły, która interweniowałaby [bezpośrednio] celem poprawiania tych czynności lub ich dokonywania. Zdaniem włoskiego autora wszystkie te czynności znajdują pełne wytłumaczenie ,fizyczne” w obrębie wszechświata i stąd

113 Btędy w krytyce dowodu kinetycznego teodycei, 523.

114 O argumentacji $z$ zakresu fizyki $w$ dyskusji światopoglądowej, „Znak" 12 (1960) $1486-1487$. 
odwoływanie się w ich przypadku do [bezpośredniego] zewnętrznego motoru transcendentnego jest rzeczą zbędną.

Niemniej jednak Masi jest zdania, że „fizyczne” tłumaczenie immanentne pozostawia miejsce na argumentację za istnieniem owego motoru. J tak, chociaż rozwój rośliny z nasienia dokonuje się na mocy jego wewnętrznej siły, to jednak ten rozwój stanowi przechodzenie $\mathrm{z}$ możności do aktu, a tego rodzaju postęp ontologiczny może - według Masiego tłumaczyć się metafizycznie tylko przez [bezpośrednią] interwencję pozaświatowego motoru, skoro zewnętrzne okoliczności wilgotności, ciepła, wyżywienia itd. są tylko warunkami, a nie przyczynami omawianego rozwoju.

Konieczność odwoływania się do wymienionego motoru narzuca się również - zdaniem Masiego - gdy chcemy sobie wytłumaczyć uruchomienie złożonego dynamizmu zwierzęcia, na przykład psa, który biegnie celem zdobycia pokarmu. Tłumaczenie ,fizyczne” przy pomocy instynktu głodu nie może stanowić ostatecznego tłumaczenia, gdyż zachowanie się zwierzęcia jest przechodzeniem z możności do aktu, a jako takie domaga się [bezpośredniej] aktualizacji ze strony czynnika spoza biokosmosu.

Aktywność człowieka można sobie tłumaczyć immanentnie pierwszym impulsem woli, ale takie tłumaczenie nie uwalnia jeszcze - jak sądzi Masi - od dalszego tłumaczenia o charakterze metafizycznym. Wola jest w swym działaniu przechodzeniem z możności do aktu i dlatego domaga się dla swej aktualizacji przyczyny transcendentnej w stosunku do świata, gdyż sama posiada uzdolnienie do działania w jego tylko obrębie ${ }^{115}$.

Te wywody Masiego nie mogą nas przekonać. Jeżeli jest się przekonanym, że słusznie $w$ naukach doświadczalnych podziela się zdanie, iż kosmos materialny odznacza się pełnym uzdolnieniem do wykonywania wszystkich właściwych dla siebie przejawów aktywności, to, przechodząc na teren metafizyki, czy raczej innej nauki filozoficznej, nie można utrzymywać posługując się teorią możności i aktu, żeby przy rozwoju rośliny z nasienia lub przy uruchomieniu psychofizycznego dynamizmu zwierzęcia czy przy aktualizacji woli ludzkiej trzeba było sięgać do b e zpośredniej interwencji pozaświatowego motoru. $Z$ akceptowanym przez Masiego tłumaczeniem „fizycznym" można zharmonizować wyłącznie tę argumentację filozoficzną, która odwołuje się do pośredni e go pozaświatowego sprawcy ruchu. Ta bowiem tylko argumentacja jest implikowana redukcyjnie przez tłumaczenie „fizyczne”. Próba godzenia tego tłumaczenia z tłumaczeniem, nazwanym przez Masiego metafizycznym, nie jest wolna od sprzeczności.

115 De prima via, w: De Deo in philosophia S. Thomae et in hodierna philosophia (Acta VI Congressus Thomistici Internationalis), vol. I, Romae 1965, 16-19. 
4. Jak przedstawia się typ epistemologic zny i metodolog i c z n y rozpatrywanej obecnie formy argumentacji kinetycznej?

Nie ulega wątpliwości, że jest ona cała w swym wydźwięku treściowym rozumowaniem filozoficz ny m. Dokładniej formułując nasze spostrzeżenie powiemy, że ta argumentacja obejmuje same pojęcia o charakterze ontologicznym. Są to pojęcia zapożyczone z dziedziny filozofii przyrody i metafizyki oraz pojęcia specyficzne dla filozofii Boga. Pojęcia i teorie z zakresu współczesnej fizyki zostały wykorzystane z tytułu zewnętrznej informacji, tak że znajdują się poza formalną osnową treściową analizowanego obecnie typu argumentacji kinetycznej. Ten sposób wykorzystania osiągnięć współczesnej fizyki domaga się bliższych wyjaśnień, gdyż niejednokrotnie nie znajduje on zrozumienia.

Według St. Kamińskiego można tu mówić o genetycznej, psychologicznej, a nie metodologicznej zależności rozumowania filozoficznego od fizyki. W szczególności Kamiński nie widzi, żeby omawianą zależność, jeżeli ją kto pojmuje jako zależność metodologiczną, można było nazywać zależnością pośrednią. „Co to jest bowiem zależność pośrednia? pytaı się lubelski metodolog - Za pośrednictwem czego? Powiedzenie zależność pośrednia, jeśli bliżej nie zostanie zdeterminowane, nic metodologowi nie powie". Zdaniem Kamińskiego nie ma również uzasadnienia mówienie o transponowaniu pojęć fizyki na pojęcia filozoficzne. „Przy transponowaniu jednego pojęcia $\mathrm{z}$ jednej dziedziny do drugiej trzeba pamiętać o tym, że inny aspekt rzeczywistości jest przedmiotem jednej nauki, a inny drugiej. Transponować przeto znaczy przenieść oznaczanie słowa na inny aspekt. Jeżeli przenosić na inny aspekt, to po co z tamtego przenosić na ten. Lepiej po prostu powiedzieć, że pozostaje tylko słowo, bo sens trzeba zasadniczo zmienić, aby właściwie odnieść słowo do odmiennego typu desygnatów" ${ }^{116}$.

Te uwagi krytyczne Kamińskiego trudno uznać za przekonywające. Jeżeliby $\mathrm{w}$ rozpatrywanym przez nas przypadku chodziło o zależność psychologiczną rozumowania filozoficznego od fizyki, rozumowanie to mogłoby rozmaicie się kształtować w swej osnowie, gdyż bodziec psychologiczny, jako coś więcej lub mniej irracjonalnego, nie jest w stanie wyznaczyć jednego, dostatecznie uzasadnionego, zwartego logicznie toku myśli. Tymczasem gdy bardzo prawdopodobną w fizyce koncepcję kinetyczną materii przetransponujemy $w$ obręb poznania $\mathrm{z}$ zakresu filozofii przyrody i gdy przy ontologicznym ujęciu ruchu ściśle rozumianego nie posłużymy się jego definicją arystotelesowską, problem istnienia pierw-

116 Wypowiedź na wymienionym wyżej krakowskim sympozjum filozoficznym z r. 1968 . W sprawozdaniu Morawca s. $239-240$. 
szego motoru może przedstawić się nam na jeden tylko sposób, mianowicie jako zagadnienie pośredniego pozaświatowego sprawcy ruchu materii ${ }^{117}$. Wewnętrzna logika tego zagadnienia, nie dopuszczająca innego rozwiązania, nie może tłumaczyć się zależnością psychologiczną od poznania fizykalnego. Zależność ta może być tylko zależnością metodologiczną. Nazwanie jej zależnością pośrednią ma wystarczającą podstawę. Starałem się to wykazać w $\S 2$, n. 1, gdzie wskazałem na szeroko rozumiane poznanie ontologiczne jako na czynnik pośredniczący w recepcji ustaleń fizyki ${ }^{118}$. W przypadku tej recepcji można mówić o transpozycji noetycznej. Nie polega ona na tym, że, jak sądzi Kamiński, zmienia się zasadniczo sens wyrazu, odnosząc go w innej nauce do odmiennego typu desygnatów. W transpozycji, którą mam na uwadze, pozostaje nie samo słowo powtórzone za fizykiem przez filozofa, lecz coś z samego poznania fizykalnego. Jest to wyrażona językiem potocznym najistotniejsza treść tego, co w fizyce zostało ustalone w przedmiocie stosunku ruchu do materii. Do tego rodzaju ogólnego ujęcia doszło w następstwie abstrahowania od elementów specyficznych dla poznania z dziedziny fizyki. I gdy to ogólne ujęcie, stanowiące bardzo zredukowany, ale jeszcze wystarczający warunek korzystania $\mathrm{z}$ osiągnięć fizyki, wprowadzimy w obręb kosmologicznej partii filozofii Boga, określimy je bliżej, jak zrobilibyśmy z każdym innym potocznym ujęciem, po linii pojęć ontologicznych szeroko rozumianych ${ }^{119}$. Będziemy więc tłumaczenie bytu podległego ruchowi w znaczeniu ścisłym wyrażali w samych tylko terminach filozoficznych. Nie widzę, żeby takiemu postępowaniu można było zarzucić brak poprawności metodologicznej. Nie chodzi tu przecież o dalszy ciąg poznania fizykalnego.

Rozpatrzmy krytycznie jeszcze inne wywody Kamińskiego na rzecz pełnej autonomiczności argumentacji kinetycznej w stosunku do fizyki.

117 Por. wyżej § 3 n. 1.

118 Sam Kamiński zauważył $\mathrm{w}$ art. Zagadnienia metodologiczne związane $z$ filozofia Boga (s. 394), że nauki szczególowe mogą pośrednio warunkować określoną problematykę filozoficzną, chociaż w przypadku zagadnienia istnienia Boga taka ich rola jest, jego zdaniem, mała. Ale już w art. Poznawalność istnienia Boga, napisanym wspólnie ze Zdybicką, Kamiński rozpoczął adwrót od tego twierdzenia, gdyż wplyw nauk szczegółnwych na filozofię określił (na s. 71) jako pośredni i psychologiczny.

${ }_{119} \mathrm{~W}$ art. Zagadnienia metodologiczne zwiazane $z$ filozofia Boga (s. 393) Kamiński pisał, że dokonując filozoficznej konstrukcji danych doświadczenia naukowego, „dokonuje się niepotrzebnej roboty przekładania”, gdyż ,dane doświadczenia trzeba od razu ujmować filozoficznie". Ale jeżelibyśmy poszli za tymi wskazówkami metodologicznymi Kamińskiego, musielibyśmy adseparować się przy filozofowaniu od wszelkich ustaleń w obrębie nauk szczegółowych, gdyż tylko wtedy uniknęlibyśmy, ,niepotrzebnej roboty przekładania”. W dalszej knnsekwencji ograniczylibyśmy wydatnie zakres badań filozoficznych, nie wychodząc poza dane doświadczenia potocznego. Por. art. Ka mińskiego i $\mathrm{Zdybickiej} \mathrm{Poznawalność}$ istnienia Boga (s. 71). 
Jego zdaniem nie liczylibyśmy się z odrębnością przedmiotu formalnego klasycznej metafizyki ogólnej i fizyki, gdybyśmy przy ostatecznym tłumaczeniu genezy ruchu, zmiany, należącym do pierwszej z tych nauk ${ }^{120}$, chcieli korzystać z osiągnięć drugiej nauki ${ }^{121}$. Skoro jednak fizyka doszła do nie znanych dawniej ustaleń w zakresie stosunku ruchu do materii, nie widać dlaczego, po uwolnieniu ich w drodze abstrakcji od ujęcia specyficznie fizykalnego, nie moglibyśmy ich badać z punktu widzenia filozofii klasycznej i uwzględniać przy konstruowaniu jednej z form argumentacji kinetycznej, tej, którą obecnie analizujemy. Jeżelibyśmy odrzucali tu wszelką możliwość filozoficznego spożytkowania fizyki, separowalibyśmy od siebie badania filozoficzne i fizykalne tak, jak to czyni Kamiński, a za nim Edmund Morawiec, którzy utrzymują, że metafizyka i fizyka urabiają swoje pojęcia w oparciu o odrębny materiał empiryczny, gdyż ich przedmiot formalny jest różny. Tymczasem odrębność ich przedmiotu formalnego nie zmusza do zajęcia tak skrajnego stanowiska. Odrębne specyficzne punkty widzenia mogą odnosić się do tego samego materiału empirycznego. Stąd też może on być poznawczo wykorzystywany w różnych naukach, powiązanych zależnością w sensie metodologicznym. Może ktoś opowiadać się za taką koncepcją, według której metafizyka bierze za swój punkt wyjścia aspekt rzeczywistości, jakim nie zajmuje się fizyka i inne nauki szczegółowe, mianowicie istnienie w ogólności. Niech jednak nie absolutyzuje tej swej konwencji i nie twierdzi, że kto jej nie podziela, już przez to samo nie uprawia filozofii w sensie klasycznym, wprowadzając pozór metody filozoficznej.

5. Czy metoda, która została użyta w rozpatrywanej obecnie wersji argumentacji kinetycznej, może być nazwana scjentys tyczno-i ntuicyjną, jak określił całą moją metodę filozofowania Kamiński? ${ }^{122}$

Żeby można było odpowiedzieć na to pytanie w sposób wolny od

$120 \mathrm{~W}$ związku z przydzielaniem przez Kamińskiego astatecznego tlumaczenia genezy ruchu dla klasycznej metafizyki ogólnej przytoczę jego nowszą wypowiedź: „Nie ma [...] poznawczego dostępu do Boga innego jak eksplanatywno-relacyjny, $\mathrm{z}$ tym, że w aspekcie ogólnoegzystencjalnym wskazana racja jest najbardziej fundamentalna i pełna. $\mathrm{Z}$ tego powodu właśnie racjonalne poznanie Boga dokonuje się podstawowo i właściwie w ramach klasycznej metafizyki ogólnej (teorii bytu)". (Poznanie Boga a typy racjonalnego poznania, "Studia Philosophiae Christianae", 17 (1981, nr 1) 152). Nie trudno zauważyć znając całokształt poglądów filozoficznych Kamińskiego, że racją uzasadniającą jego ostatnie twierdzenie nie jest to, co je poprzedza, lecz sui generis konkretystyczna interpretacja przedmiotu formalnego metafizyki.

121 Por. w sprawozdaniu Morawca z krakowskiego sympozjum filozoficznego (z r. 1968) s. 238-243. Zob. jeszcze: $\mathrm{K}$ a mińs ki, Metodologiczna problematyka poznania Boga, 298-299; id., Zagadnienia metodologiczne zwiazane $z$ filozofia Boga, 392-393; Kamiński i Zdybicka, Poznawalność istnienia Boga, 70-71. Po linii poglądów Kamińskiego poszedł Mor awie c w art. Nauki szczegótowe, filozofia a poznanie istnienia Boga, 28-30.

122 Metody wspótczesnej metafizyki (cz. II), „Roczniki Filozoficzne”, 26 (1978, z. 1) $29-31$. 
uproszczeń, musimy wpierw przebadać, które z metod scjentystycznych nie dają się zharmonizować z poznaniem specyficznym dla filozofii. Mówiąc tu o metodach scjentystycznych mam na uwadze metody, przy których, niezależnie od ich zróżnicowania, zakłada się, że filozoficzna teoria rzeczywistości nie jest w pelni autonomiczna w stosunku do teorii poznania nauk szczegółowy ch ${ }^{123}$. W dalszych wywodach uwzględnię, jak dotąd, sam tylko stosunek filozoficznej teorii rzeczywistości do nauk szczegółowych.

Do metod scjentystycznych, które nie spełniają wymagań, jakim podlega poznanie filozoficzne, należą niewątpliwie próby rozstrzygania zagadnién filozoficznych metodami nauk przyrodniczych lub w drodze wyprowadzania bezpośrednich wniosków z nakowego poznania przyrody. Tej formy scjentyzmu nie ma w rozpatrywanym obecnie typie argumentacji kinetycznej. Nie zakłada on przesłanek o treści charakterystycznej dla fizyki i ustalonych jej metodami. Przed taką zależnością epistemologiczną i metodologiczną chroni go transpozycja ustaleń fizykalnych, o której już była mowa. Transpozycja uniemożliwia także wyprowadzenie bezpośrednich wniosków z tych ustaleń.

Jeżelibyśmy za scjentystyczne uprawianie filozofii uważali takie, które, gdzie to okazuje się korzystne, uwzględnia w odpowiedni sposób w swym punkcie wyjścia nie poznanie potoczne, lecz naukowe, to a n a lizowana obecnie wersja argumentacji kinetycznej jest wyrazem takiego scjentyzmu. Nie uważam go jednak za coś metodycznie niepoprawnego, gdyż naukowe poznanie przyrody przewyższa jej poznanie potoczne pod względem zasobu informacji, precyzji i stopnia pewności. Gdybyśmy przy próbach konstruowania argumentacji kinetycznej wyszli od aspektu rzeczywistości, którego nauki szczególowe nie badają, to jest od istnienia, zredukowalibyśmy wydatnie zakres naszych prób.

Kamiński chciałby uwolnić argumentację kinetyczną (,dowód kinetyczny", jak się wyraża) od wszelkich powiązań z fizyką, a tym samym od jakiejkolwiek formy scjentyzmu. Gdy zrealizuje się ten postulat, argumentacja $\mathrm{z}$ ruchu stanie się - według niego - prostsza i nie będzie miała zarzucanych jej trudności ${ }^{124}$. Ale Kamiński utrzymuje tak głównie dlatego, że, z racji ograniczającego wpływu podzielanej przez siebie teorii metafizyki, zdobył dobrą orientację $\mathrm{w}$ jednym tylko etapie argumentacji

123 Jest to $w$ zasadzie określenie Kamińskiego z dopiero co cytowanej rozprawy, s. 27.

${ }_{124}$ Zob. w sprawozdaniu Morawca $\mathrm{z}$ krakowskiego sympozjum filozoficznego s. $242-243$. 
kinetycznej, w którym jakakolwiek łączność z fizyką jest zbędna. O tym typie argumentacji będzie mowa w drugiej części obecnego § 3 , gdzie go rozpatrzę z pozycji tomizmu.

§ 3. 2. Formy argumentacji kinetycznej niezależne od fizyki współczesnej

1. Przez szereg lat utrzymywałem, że analizowany typ argumentacji kinetycznej jest jedyną jej formą, jaką obecnie można przyjąć. Jeszcze $\mathrm{w}$ pracy $Z$ zagadnien filozoficznego poznania Boga pisałem, ,że każda próba [...] argumentacji [kinetycznej], jeżeli jej punktem wyjścia ma być [...] realny ruch konkretny, stale miany na uwadze przy stosowaniu filozoficznych zabiegów definicyjnych, musi pozostawać w swym szczegółowym ukształtowaniu w pośredniej zależności od tego, co w płaszczyźnie fizyki zostało ustalone o stosunku ruchu do materii" ${ }^{125}$.

To przekonanie tłumaczyło się tym, że przy Tomaszowych wariantach argumentacji kinetycznej, wyjąwszy jej drugą postać z Sum. c. Gent., koncentrowałem się głównie na ich modernizacji przez uzgodnienie ze współczesnym przyrodniczym obrazem świata ${ }^{126}$. Takie zadanie narzucało mi się nawet w przypadku argumentacji z Sumy teologii, gdyż jak wykazywałem przy jej analizie, nie jest to rozumowanie, które byłoby w sobie niezależne od trzynastowiecznego obrazu przyrodniczego świata.

Ale choć jest ono w zasadzie identyczne z pierwszym wariantem argumentacji kinetycznej z Sum. c. Gent., to jednak zastosowanie w dużej jego części samej tylko teorii możności i aktu do bytów danych w obrębie percepcji zmysłowej i poruszających się ruchem w znaczeniu ścisłym, czyni te wywody szczególnie podatne na przekształcenie $\mathrm{w}$ argumentację filozoficzną, niezależną od fizyki współczesnej. W pierwszym przybliżeniu moglibyśmy powiedzieć, że rozumowanie z Sum. theol. jest takie, że gdy je sprowadzimy do jego zasadniczej myśli, daje się oderwać od jakiegokolwiek przyrodniczego obrazu świata. Wyrazimy się jednak precyzyjniej i będziemy liczyli się bardziej z faktycznym rozumowaniem Tomasza, gdy zauważymy, że nie wszystko jest $w$ nim jednakowo wartościowe i niezbędne do ostatecznego wytłumaczenia genezy ruchu. Okazuje się bowiem, że aby dojść do tego celu, wystarczy podjąć od autora Sumy teologii koncepcję ruchu jako aktualizacji możliwości i badać, co ta koncepcja implikuje redukcyjnie, gdy odwołujemy się do ontologicznej zasady racji dostatecznej. A wtedy będziemy mogli pominąć tezę głoszącą niemożliwość posuwania się $\mathrm{w}$ nieskończoność $\mathrm{w}$ serii bytów poru-

125 S. $71-72$.

126 Drukiem ogłosiłem tylko analizę i ocenę pierwszej wersji argumentacji kinetycznej z Sumy filozoficznej, ale na swych wykładach rozpatrywałem krytycznie przez kilka lat wszystkie Tomaszowe odmiany tej argumentacji. 
szanych kolejno przez inny byt - tę tezę, która zakłada stosownie do trzynastowiecznego obrazu przyrodniczego świata, że ciała nieożywione wprawiają $\mathrm{w}$ ruch inne tego rodzaju ciała, o ile podlegają aktualnemu poruszaniu z zewnątrz. Wraz z pominięciem tej tezy odpada powiązanie rozumowania Tomasza za średniowiecznymi wyobrażeniami przyrodniczymi. Nie potrzebujemy także uzależniać go od fizyki współczesnej.

2. Zauważono to już w filozoficznej szkole lubelskiej, która przyjmując $\mathrm{w}$ drodze nieuświadomionej konwencji istnienie jakı punkt wyjścia filozofii - metafizyki, opowiada się za jej pełną autonomią w stosunku do nauk szczegółowych, nie zajmujących się wymienionym aspektem rzeczywistości. Ale argumentacja kinetyczna, całkowicie niezależna od fizyki współczesnej, nie jest jedynym rozumowaniem z ruchu na istnienie Boga. Dopuszczalna jest także, jak wykazywałem, argumentacja kinetyczna zależna w odpowiedni sposób od tego, co fizyka ustaliła w przedmiocie stosunku ruchu do materii. Z racji systemowych nie ma jednak miejsca na taką argumentację w filozoficznej szkole lubelskiej. Jest natomiast na nią miejsce $\mathrm{w}$ tomizmie lowańskim, z którego pozycji można jeszcze podjąć argumentację kinetyczną niezależną od fizyki, gdy tą argumentację uwolni się od zniekształceń tomizmu egzystencjalnego, do jakich należy pojmowanie ruchu jako stawania się istnienia a Pierwszego Poruszyciela jako czystego istnienia realnego.

W filozoficznej szkole lubelskiej wyodrębniono jedną tylko formę argumentacji kinetycznej, niezależnej od fizyki współczesnej. Tłumaczy się to tym, że w tej szkole za ruch w znaczeniu ścisłym uważa się nie tylko zmiany realizowane sukcesywnie, ale również zmiany momentalne, jakie zachodzą w przypadku czynności naszego umysłu i woli. Ale jeżeli wyodrębnia się dwa typy ruchu, jeden w znaczeniu ścisłym, do którego stosuje się arystotelesowska definicja ruchu, i drugi w sensie metaforycznym obejmujący zmiany momentalne, do którego ta definicja się nie odnosi, będziemy mogli wyróżniać dwa rodzaje argumentacji kinetycznej, niezależnej od współczesnych poglądów fizykalnych. Sygnalizowałem je już w niniejszym artykule $(\S 1, n .4)$. W tomizmie egzystencjalnym szkoły lubelskiej byłoby możliwe ich rozróżnienie, gdyż pogląd na zasięg ruchu w znaczeniu ścisłym, jaki podziela się w tej szkole, jest dla niej czymś przygodnym i nie tłumaczy się wewnętrzną logiką systemu.

Gdy ujmujemy ruch w znaczeniu ścisłym od strony jego cząstkowego i sukcesywnego przechodzenia $\mathrm{z}$ możności do aktu, a ruch w sensie metaforycznym $\mathrm{w}$ aspekcie jego momentalnej aktualizacji, możemy skonstruować bardzo oczywistą argumentację za istnieniem bytu, który jest Czystym Aktem - Bogiem. Ta argumentacja będzie odpowiadała szczególnie umysłom o orientacji humanistycznej. Natomiast filozof o dodatkowej formacji przyrodniczej będzie odczuwał pewien niedosyt, gdyż 
w tej argumentacji nie zostało ukazane przyporządkowanie pojęć możności i aktu do współczesnego przyrodniczego obrazu świata. Całe rozumowanie stanowi jakby most przerzucony bez żadnych słupów podporowych nad kosmosem w ujęciu przyrodniczym, który stanowi jeden gigantyczny proces. Niemniej jednak filozof zauważy, że rozpatrywana obecnie argumentacja kinetyczna nie implikuje dedukcyjnie i redukcyjnie niczego, co byłoby niezgodne z poglądami fizyki współczesnej.

\section{THE STUDY ON KINETIC ARGUMENTS FOR THE EXISTENCE OF GOD}

\section{S u m m a r y}

The paper contains critical studies of various versions of the so called kinetic arguments for the existence of God. Its content was supposed to be included to the second volume of the book $\mathrm{Z}$ zagadnien filozoficznego poznania Boga. The death of Prof. Kłósak on 1 June 1982 broke down his work on the book. Its fragments prepared during last months of Klósak's life, in the period of his struggle against increasing cardiac problems, are published in this issue of Analecta.

In the paper Kłósak presents his critical opinion on various classical versions of the kinetic arguments. After assessing the kinetic arguments of Thomas Aquinas, the author tries again to substantiate his strong opposition against some neo-Thomist amendments to the argument proposed, among others, by M. Krąpiec, J. Dorda, F. Selvaggi, R. Masi.

After the critical appraisal in which many opinions of Klósak's earlier critiques are repeated, the author analyses new scientific background of the argument on the basis of the discussion during the interdisciplinary seminar arranged by Card. Wojtyła in 1968. In final fragments of the paper two new versions of the argument are proposed. In first of them physical premises are used in order to replace the Aristotelian physics contained in St. Thomas' arguments by the relativistic theory of motion. In this new attitude the attention is focused on the fact of ontic contingency of physically conceived mation. In the second argument, independent of physical theories of motion, the author introduces metaphysical categories of potentiality and act to substantiate the existence of the Pure Act which justifies kinetic changes expressed in transitions from potentiality to act. 